\title{
References
}

Hypertension Research (2009) 32, 91-107; doi:10.1038/hr.2008.15

1 Ueshima H. Explanation for the Japanese paradox: prevention of increase in coronary heart disease and reduction in stroke. J Atheroscler Thromb 2007; 14: 278-286. RV

2 Kubo M, Kiyohara Y, Kato I, Tanizaki Y, Arima H, Tanaka K, Nakamura H, Okubo K, lida $M$. Trends in the incidence, mortality, and survival rate of cardiovascular disease in a Japanese community: the Hisayama study. Stroke 2003; 34: 2349-2354. OS

3 Kitamura A, Iso H, lida M, Naito Y, Sato S, Jacobs DR, Nakamura M, Shimamoto T, Komachi Y. Trends in the incidence of coronary heart disease and stroke and the prevalence of cardiovascular risk factors among Japanese men from 1963 to 1994. Am J Med 2002; 112: 104-109. OS

4 Kimura Y, Takishita S, Muratani H, Kinjo K, Shinzato Y, Muratani A, Fukiyama K. Demographic study of first-ever stroke and acute myocardial infarction in Okinawa, Japan. Intern Med 1998; 37: 736-745. OS

5 Lawes CM, Rodgers A, Bennett DA, Parag V, Suh I, Ueshima H, MacMahon S, Asia Pacific Cohort Studies Collaboration. Blood pressure and cardiovascular disease in the Asia Pacific region. J Hypertens 2003; 21: 707-716. MA

6 Nippon Data 80 Research Group. Impact of elevated blood pressure on mortality from all causes, cardiovascular diseases, heart disease and stroke among Japanese: 14 year follow-up of randomly selected population from Japanese-Nippon data 80. J Hum Hypertens 2003; 17: 851-857. OS

7 Tanizaki Y, Kiyohara Y, Kato I, Iwamoto H, Nakayama K, Shinohara N, Arima H, Tanaka K, Ibayashi S, Fujishima M. Incidence and risk factors for subtypes of cerebral infarction in a general population: the Hisayama study. Stroke 2000; 31 : 2616-2622. OS

8 Arima H, Tanizaki Y, Kiyohara Y, Arima H, Tanizaki Y, Kiyohara Y, Tsuchihashi T, Kato I, Kubo M, Tanaka K, Ohkubo K, Nakamura H, Abe I, Fujishima M, lida M. Validity of the JNC VI recommendations for the management of hypertension in a general population of Japanese elderly: the Hisayama study. Arch Intern Med 2003; 163: 361-366. OS

9 Lewington S, Clarke R, Qizilbash N, Peto R, Collins R, Prospective Studies Collaboration. Age-specific relevance of usual blood pressure to vascular mortality: a metaanalysis of individual data for one million adults in 61 prospective studies. Lancet 2002; 360: 1903-1913. MA

10 lino Y, Hayashi M, Kawamura T, Shiigai T, Tomino Y, Yamada K, Kitajima T, Ideura T, Koyama A, Sugisaki T, Suzuki H, Umemura S, Kawaguchii Y, Uchida S, Kuwahara M, Yamazaki T, Japanese Losartan Therapy Intended for the Global Renal Protection in Hypertensive Patients (JLIGHT) Study Investigators. Renoprotective effect of losartan in comparison to amlodipine in patients with chronic kidney disease and hypertension-a report of the Japanese Losartan Therapy Intended for the Global Renal Protection in Hypertensive Patients (JLIGHT) study. Hypertens Res 2004; 27: 21-30. RT

11 Ninomiya T, Kiyohara Y, Kubo M, Tanizaki Y, Doi Y, Okubo K, Wakugawa Y, Hata J, Oishi Y, Shikata K, Yonemoto K, Hirakata H, lida M. Chronic kidney disease and cardiovascular disease in a general Japanese population: the Hisayama Study. Kidney Int 2005; 68: 228-236. OS

12 Nakamura K, Okamura T, Hayakawa T, Kadowaki T, Kita Y, Ohnishi H, Saitoh S, Sakata K, Okayama A, Ueshima H, The NIPPON DATA90 Research Group. Chronic kidney disease is a risk factor for cardiovascular death in a community-based population in Japan: NIPPON DATA90. Circ J 2006; 70: 954-959. OS

13 Takeuchi H, Saitoh S, Takagi S, Ohnishi H, Ohhata J, Isobe T, Shimamoto K. Metabolic syndrome and cardiac disease in Japanese men: applicability of the concept of metabolic syndrome defined by the National Cholesterol Education Program-Adult Treatment Panel III to Japanese men-the Tanno and Sobetsu Study. Hypertens Res 2005; 28: 203-208. OS

14 Iso H, Sato S, Kitamura A, Imano H, Kiyama M, Yamagishi K, Cui R, Tanigawa T, Shimamoto T. Metabolic syndrome and the risk of ischemic heart disease and stroke among Japanese men and women. Stroke 2007; 38: 1744-1751. OS

15 Ninomiya T, Kiyohara Y, Kubo M, Yonemoto K, Tanizaki Y, Doi Y, Hirakata H, lida M. Metabolic syndrome and CKD in a general Japanese population: the Hisayama Study. Am J Kidney Dis 2006; 48: 383-391. OS

16 Ninomiya T, Kubo M, Doi Y, Yonemoto K, Tanizaki Y, Rahman M, Arima H, Tsuryuya K, lida M, Kiyohara Y. Impact of metabolic syndrome on the development of cardiovascular disease in a general Japanese population: the Hisayama study. Stroke 2007; 38: 2063-2069. OS

17 Nakamura Y, Yamamoto T, Okamura T, Kadowaki T, Hayakawa T, Kita Y, Saitoh S, Okayama A, Ueshima H, The NIPPON DATA 80 Research Group. Combined cardio- vascular risk factors and outcome: NIPPON DATA80, 1980-1994. Circ J 2006; 70: 960-964. OS

18 Kadota A, Hozawa A, Okamura T, Kadowak T, Nakmaura K, Murakami Y, Hayakawa T, Kita Y, Okayama A, Nakamura Y, Kashiwagi A, Ueshima H, NIPPON DATA Research Group. Relationship between metabolic risk factor clustering and cardiovascular mortality stratified by high blood glucose and obesity: NIPPON DATA9, 19902000. Diabetes Care 2007; 30: 1533-1538. OS

19 Saito I, Konishi M, Watanabe K, Kondo H, Fujimotos K, Okada K. The metabolic syndrome and risk of stroke in a rural community in Japan. Nippon Koshu Eisei Zasshi 2007; 54: 677-683. Japanese.

20 Okayama A, Kadowaki T, Okamura T, Hayakawa T, Ueshima H, The NIPPON DATA80 Research Group. Age-specific effects of systolic and diastolic blood pressures on mortality due to cardiovascular diseases among Japanese men (NIPPON DATA80). J Hypertens 2006; 24: 459-462. OS

21 Murakami Y, Hozawa A, Okamura T, Ueshima H, Evidence for Cardiovascular Prevention From Observational Cohorts in Japan Research Group (EPOCH-JAPAN). Relation of blood pressure and all-cause mortality in 180000 Japanese participants: pooled analysis of 13 cohort studies. Hypertension 2008; 51: 1483-1491. MA

22 Lawes CM, Bennett DA, Parag V, Woodward M, Whitlock G, Lam TH, Suh I, Rodgers A, Asia Pacific Cohort Studies Collaboration. Blood pressure indices and cardiovascular disease in the Asia Pacific region: a pooled analysis. Hypertension 2003; 42: 69-75. OS

23 Miura K, Soyama Y, Morikawa Y, Nishijo M, Nakanishi Y, Naruse Y, Yoshita K, Kagamimori S, Nakagawa $\mathrm{H}$. Comparison of four blood pressure indexes for the prediction of 10-year stroke risk in middle-aged and older Asians. Hypertension 2004; 44: 715-720. OS

24 Inoue R, Ohkubo T, Kikuya M, Metoki H, Asayama K, Obara T, Hoshi H, Hashimoto J, Totsune K, Satoh H, Kondo Y, Imai Y. Predicting stroke using 4 ambulatory blood pressure monitoring-derived blood pressure indices: the Ohasama Study. Hypertension 2006; 48: 877-882. RT

25 Thorvaldsen P, Asplund K, Kuulasmaa K, Rajakangas AM, Schroll M. Stroke incidence, case fatality, and mortality in the WHO MONICA project. World Health Organization Monitoring Trends and Determinants in Cardiovascular Disease. Stroke 1995; 26: 361-367. OS

26 Kita Y, Okayama A, Ueshima H, Wada M, Nozaki A, Choudhury SR, Bonita R, Inamoto Y, Kasamatsu T. Stroke incidence and case fatality in Shiga, Japan 1989-1993. Int J Epidemiol 1999; 28: 1059-1065.

27 Kinjo K, Kimura Y, Shinzato Y, Tomori M, Komine Y, Kawazoe N, Takishita S, Fukiyama $\mathrm{K}$ and COSMO Group. An epidemiological analysis of cardiovascular diseases in Okinawa, Japan. Hypertens Res 1992; 15: 111-119. OS

28 Morikawa Y, Nakagawa H, Naruse Y, Nishijo M, Miura K, Tabata M, Hirokawa W, Kagamimori S, Honda M, Yoshita K, Hayashi K. Trends in stroke incidence and acute case fatality in a Japanese rural area: the Oyabe study. Stroke 2000; 31: 1583-1587. OS

29 Kiyohara Y, Kubo M, Kato I, Tanizaki Y, Tanaka K, Okubo K, Nakamura H, lida M. Ten-year prognosis of stroke and risk factors for death in a Japanese community: the Hisayama study. Stroke 2003; 34: 2343-2347. OS

30 Intersalt Cooperative Research Group. Intersalt: an international study of electrolyte excretion and blood pressure. Results for $24 \mathrm{~h}$ urinary sodium and potassium excretion. BMJ 1988; 297: 319-328. OS

31 Nakagawa H, Morikawa Y, Okayama A, Fujita Y, Yoshida Y, Mikawa K, Sakata K, Ishizaki M, Miura K, Naruse Y, Kagamimori S, Hashimoto T, Ueshima H. Trends in blood pressure and urinary sodium and potassium excretion in Japan: reinvestigation in the 8th year after the Intersalt Study. J Hum Hypertens 1999; 13: 735-741. OS

32 Stamler J, Elliott P, Chan Q, INTERMAP Research Group. ITNTERMAP Appendix tables. J Hum Hypertens 2003; 17: 665-775. OS

33 The INTERSALT Co-operative Research Group. Appendix tables. Centre-specific results by age and sex. J Hum Hypertens 1989; 3: 331-407. OS

34 Sacks FM, Svetkey LP, Vollmer WM, Appel LJ, Bray GA, Harsha D, Obarzanek E, Conlin PR, Miller III ER, Simons-Morton DG, Karanja N, Lin PH, DASH-Sodium Collaborative Research Group. Effects on blood pressure of reduced dietary sodium and the Dietary Approaches to Stop Hypertension (DASH) diet. DASH-Sodium Collaborative Research Group. N Engl J Med 2001; 344: 3-10. RT

35 Nakamura K, Okamura T, Hayakawa T, Hozawa A, Kadowaki T, Murakami Y, Kita Y, Okayama A, Ueshima H, NIPPON DATA80, 90 Research Group. The proportion of 
individuals with obesity-induced hypertension among total hypertensives in a general Japanese population: NIPPON DATA80, 90. Eur J Epidemiol 2007; 22: 691-698. OS

36 Tanaka T, Okamura T, Yamagata Z, Takebayashi T, Tamura U, Kusaka Y, Urano S, Miyoshi Y, Okayama A, Ueshima H, HIPOP-OHP Research Group. Awareness and treatment of hypertension and hypercholesterolemia in Japanese workers: the Highrisk and Population Strategy for Occupational Health Promotion (HIPOP-OHP) study. Hypertens Res 2007; 30: 921-928. OS

37 Hozawa A, Ohkubo T, Kikuya M, Yamaguchi J, Ohmori K, Fujiwara T, Hashimoto J, Matsubar M, Kitaoka H, Nagai K, Tsuji I, Satoh H, Hisamichi S, Imai Y. Blood pressure control assessed by home, ambulatory and conventional blood pressure measurements in the Japanese general population: the Ohasama study. Hypertens Res 2002; 25: 57-63. OS

38 Chobanian AV, Bakris GL, Black HR, Cushman WC, Green LA, Izzo Jr JL, Jones DW, Materson BJ, Oparil S, Wright Jr JT, Roccella EJ. National Heart, Lung, and Blood Institute Joint National Committee on Prevention, Detection, Evaluation, and Treatment of High Blood Pressure. The Seventh Report of the Joint National Committee on Prevention, Detection, Evaluation, and Treatment of High Blood Pressure: the JNC 7 report. JAMA 2003; 289: 2560-2572. GL

39 Stamler J, Rose G, Stamler R, Elliott P, Dyer A, Marmot M. INTERSALT study findings. Public health and medical care implications. Hypertension 1989; 14: 570-577. OS

40 Fagard RH, Van Den Broeke C, De Cort P. Prognostic significance of blood pressure measured in the office, at home and during ambulatory monitoring in older patients in general practice. J Hum Hypertens 2005; 19: 801-807. OS

41 Pickering TG, Hall JE, Appel LJ, Falkner BE, Graves J, Hill MN, Jones DW, Kurtz T, Sheps SG, Roccella EJ, Subcommittee of Professional and Public Education of the American Heart Association Council on High Blood Pressure Research. Recommendations for blood pressure measurement in humans and experimental animals: part 1 : blood pressure measurement in humans: a statement for professionals from the Subcommittee of Professional and Public Education of the American Heart Association Council on High Blood Pressure Research. Hypertension 2005; 45: 142-161. GL

42 O'Brien E, Asmar R, Beilin L, Imai Y, Mallion JM, Mancia G, Mengden T, Myers M, Padfield P, Palatini P, Parati G, Pickering T, Redon J, Staessen J, Stergiou G, Verdecchia P, European Society of Hypertension Working Group on Blood Pressure Monitoring. European Society of Hypertension recommendations for conventional, ambulatory and home blood pressure measurement. J Hypertens 2003; 21: 821-848. GL

43 Ménard J, Chatellier G, Day M, Vaur L. Self-measurement of blood pressure at home to evaluate drug effects by the trough: peak ratio. J Hypertens Supp/ 1994; 12: S21-S25. RT

44 Oikawa T, Obara T, Ohkubo T, Kikuya M, Asayama K, Metoki H, Komai R, Murai K, Hashimoto J, Totsune K, Imai Y, J-HOME Study Group. Characteristics of resistant hypertension determined by self-measured blood pressure at home and office blood pressure measurements: the J-HOME study. J Hypertens 2006; 24: 1737-1743. OS

45 Fukunaga H, Ohkubo T, Kobayashi M, Tamaki Y, Kikuya M, Obara T, Nakagawa M, Hara A, Asayama K, Metoki H, Inoue R, Hashimoto J, Totsune K, Imai Y. Costeffectiveness of the introduction of home blood pressure measurement in patients with office hypertension. J Hypertens 2008; 26: 685-690.

46 Imai Y, Otsuka K, Kawano Y, Shimada K, Hayashi H, Tochikubo O, Miyakawa M, Fukiyama K, Japanese Society of Hypertension. Japanese society of hypertension (JSH) guidelines for self-monitoring of blood pressure at home. Hypertens Res 2003; 26: 771-782. GL

47 Imai Y, Obara T, Ohkubo T. How many times should we ask subjects to measure blood pressure at home on each occasion? J Hypertens 2007; 25: 1987-1991. GL

48 Kawabe H, Saito I. Which measurement of home blood pressure should be used for clinical evaluation when multiple measurements are made? J Hypertens 2007; 25: 1369-1374. OS

49 Ohkubo T, Asayama K, Kikuya M, Metoki H, Hoshi H, Hashimoto J, Totsune K, Satoh $\mathrm{H}$, Imai $\mathrm{Y}$, Ohasama Study. How many times should blood pressure be measured at home for better prediction of stroke risk? Ten-year follow-up results from the Ohasama study. J Hypertens 2004; 22: 1099-1104. OS

50 Imai Y, Munakata M, Tsuji I, Ohkubo T, Satoh H, Yoshino H, Watanabe N, Nishiyama A, Onodera N, Kato J, Sekino M, Aihara A, Kasai Y, Abe K. Seasonal variation in blood pressure in normotensive women studied by home measurements. Clin Sci (Lond) 1996; 90: 55-60. OS

51 Kikuya M, Chonan K, Imai Y, Goto E, Ishii M, Research Group to Assess the Validity of Automated Blood Pressure Measurement Devices in Japan. Accuracy and reliability of wrist-cuff devices for self-measurement of blood pressure. J Hypertens 2002; 20: 629-638. OS

52 Ohkubo T, Imai Y, Tsuji I, Nagai K, Kato J, Kikuchi N, Nishiyama A, Aihara A, Sekino M, Kikuya M, Ito S, Satoh H, Hisamichi S. Home blood pressure measurement has a stronger predictive power for mortality than does screening blood pressure measurement: a population-based observation in Ohasama, Japan. J Hypertens 1998; 16: 971-975. OS

53 Sega R, Facchetti R, Bombelli M, Cesana G, Corrao G, Grassi G, Mancia G. Prognostic value of ambulatory and home blood pressures compared with office blood pressure in the general population: follow-up results from the Pressioni Arteriose Monitorate e Loro Associazioni (PAMELA) study. Circulation 2005; 111: 1777-1783. OS

54 Hozawa A, Ohkubo T, Nagai K, Kikuya M, Matsubara M, Tsuji I, Ito S, Satoh H, Hisamichi S, Imai Y. Prognosis of isolated systolic and isolated diastolic hypertension as assessed by self-measurement of blood pressure at home: the Ohasama study. Arch Intern Med 2000; 160: 3301-3306. OS

55 Asayama K, Ohkubo T, Kikuya M, Metoki H, Obara T, Hoshi H, Hashimoto J, Totsune K, Satoh H, Imai Y. Use of 2003 European Society of Hypertension-European Society of Cardiology guidelines for predicting stroke using self-measured blood pressure at home: the Ohasama study. Eur Heart J 2005; 26: 2026-2031. OS

56 Asayama K, Ohkubo T, Kikuya M, Metoki H, Hoshi H, Hashimoto J, Totsune K, Satoh $\mathrm{H}$, Imai Y. Prediction of stroke by self-measurement of blood pressure at home versus casual screening blood pressure measurement in relation to the Joint National Committee 7 classification: the Ohasama study. Stroke 2004; 35: 2356-2361. OS

57 Nishinaga M, Takata J, Okumiya K, Matsubayashi K, Ozawa T, Doi Y. High morning home blood pressure is associated with a loss of functional independence in the community-dwelling elderly aged 75 years or older. Hypertens Res 2005; 28 : 657-663. OS

58 Stergiou GS, Baibas NM, Kalogeropoulos PG. Cardiovascular risk prediction based on home blood pressure measurement: the Didima study. J Hypertens 2007; 25: 1590-1596. Os

59 Agarwal R, Andersen MJ. Prognostic importance of clinic and home blood pressure recordings in patients with chronic kidney disease. Kidney Int 2006; 69: 406-411. OS

60 Joint National Committee on Prevention, Dectection, Evaluation, and Treatment of High Blood Pressure: The sixth report of the Joint National Committee on prevention, detection, evaluation, and treatment of high blood pressure. Arch Intern Med 1997; 157: 2413-2446. GL

61 European Society of Hypertension-European Society of Cardiology Guidelines Committee. 2003 European Society of Hypertension-European Society of Cardiology guidelines for the management of arterial hypertension. J Hypertens 2003; 21: 1011-1053. GL

62 Guidelines Subcommittee. 1999 World Health Organization-International Society of Hypertension Guidelines for the Management of Hypertension. J Hypertens 1999; 17: 151-183. GL

63 Tsuji I, Imai Y, Nagai K, Ohkubo T, Watanabe N, Minami N, Itoh O, Bando T, Sakuma M, Fukao A, Satoh H, Hisamichi S, Abe K. Proposal of reference values for home blood pressure measurement: prognostic criteria based on a prospective observation of the general population in Ohasama, Japan. Am J Hypertens 1997; 10: 409-418. OS

64 Imai Y, Ohkubo T, Tsuji I, Nagai K, Satoh H, Hisamichi S, Abe K. Prognostic value of ambulatory and home blood pressure measurements in comparison to screening blood pressure measurements: a pilot study in Ohasama. Blood Press Monit 1996; 1 (Suppl 2): S51-S58. OS

65 Japanese Society of Hypertension. Japanese Society of Hypertension guidelines for the management of hypertension (JSH 2004). Hypertens Res 2006; 29 (Suppl): S1-S105. GL

66 Mancia G, De Backer G, Dominiczak A, Cifkova R, Fagard R, Germano G, Grassi G, Heagerty AM, Kjeldsen SE, Laurent S, Narkiewicz K, Ruilope L, Rynkiewicz A, Schmieder RE, Boudier HA, Zanchetti A, Vahanian A, Camm J, De Caterina R, Dean V, Dickstein K, Filippatos G, Funck-Brentano C, Hellemans I, Kristensen SD, McGregor K, Sechtem U, Silber S, Tendera M, Widimsky P, Zamorano JL, Erdine S, Kiowski W, Agabiti-Rosei E, Ambrosioni E, Lindholm LH, Viigimaa M, Adamopoulos S, Agabiti-Rosei E, Ambrosioni E, Bertomeu V, Clement D, Erdine S, Farsang C, Gaita D, Lip G, Mallion JM, Manolis AJ, Nilsson PM, O'Brien E, Ponikowski P, Redon J, Ruschitzka F, Tamargo J, van Zwieten P, Waeber B, Williams B, Management of Arterial Hypertension of the European Society of Hypertension; European Society of Cardiology. The Task Force for the Management of Arterial Hypertension of the European Society of Hypertension (ESH) and of the European Society of Cardiology (ESC). 2007 Guidelines for the Management of Arterial Hypertension. J Hypertens 2007; 25: 1105-1187. GL

67 Fujiwara T, Nishimura T, Ohkuko T, Imai Y, HOMED-BP Study Group. Rationale and design of HOMED-BP Study: hypertension objective treatment based on measurement by electrical devices of blood pressure study. Blood Press Monit 2002; 7: 77-82. RT

68 Imai Y, Abe K, Sasaki S, Minami N, Munakata M, Sekino H, Nihei M, Yoshinaga K. Determination of clinical accuracy and nocturnal blood pressure pattern by new portable device for monitoring indirect ambulatory blood pressure. Am J Hypertens 1990; 3: 293-301. OS

69 Imai Y, Sasaki S, Minami N, Munakata M, Hashimoto J, Sakuma H, Sakuma M, Watanabe N, Imai K, Sekino H, Abe K. The accuracy and performance of the A\&D TM 2421, a new ambulatory blood pressure monitoring device based on the cuffoscillometric method and the Korotkoff sound technique. Am J Hypertens 1992; 5: 719-726. OS

70 Kuwajima I, Nishinaga M, Kanamaru A. The accuracy and clinical performance of a new compact ambulatory blood pressure monitoring device, the ES-H531. Am J Hypertens 1998; 11: 1328-1333. OS

71 Shimada K, Imai Y, Kuwajima I, Tochikubo O, Hayashi H, Kawano Y, Kawasaki K. [Guidelines for 24-h ambulatory blood pressure monitoring (ABPM)]. Jpn Circ J 2000; 64 (Suppl 5): 1207-1248. Japanese. GL

72 Sokolow M, Werdegar D, Kain HK, Hinman AT. Relationship between level of blood pressure measured casually and by portable recorders and severity of complications in essential hypertension. Circulation 1966; 34: 279-298. OS

73 Mancia G, Zanchetti A, Agabiti-Rosei E, Benemio G, De Cesaris R, Fogari R, Pessina A, Porcellati C, Rappelli A, Salvetti A, Trimarco B, SAMPLE Study Group. Ambulatory blood pressure is superior to clinic blood pressure in predicting treatment-induced regression of left ventricular hypertrophy. Study on Ambulatory Monitoring of Blood Pressure and Lisinopril Evaluation. Circulation 1997; 95: 1464-1470. OS

74 Ohkubo T, Hozawa A, Nagai K, Kikuya M, Tsuji I, Ito S, Satoh H, Hisamichi S, Imai Y. Prediction of stroke by ambulatory blood pressure monitoring versus screening blood 
pressure measurements in a general population: the Ohasama study. J Hypertens 2000; 18: 847-854. OS

75 Suzuki Y, Kuwajima I, Aono T, Kanemaru A, Nishinaga M, Shibata H, Ozawa T. Prognostic value of nighttime blood pressure in the elderly: a prospective study of 24-h blood pressure. Hypertens Res 2000; 23: 323-330. OS

76 Staessen JA, Thijs L, Fagard R, O'Brien ET, Clement D, de Leeuw PW, Mancia G, Nachev C, Palatini P, Parati G, Tuomilehto J, Webster J, Systolic Hypertension in Europe Trial Investigators. Predicting cardiovascular risk using conventional vs ambulatory blood pressure in older patients with systolic hypertension. JAMA 1999; 282: 539-546. OS

77 Agarwal R, Andersen MJ. Blood pressure recordings within and outside the clinic and cardiovascular events in chronic kidney disease. Am J Nephrol 2006; 26: 503-510. OS

78 Kikuya M, Ohkubo T, Asayama K, Metoki H, Obara T, Saito S, Hashimoto J, Totsune K, Hoshi H, Satoh H, Imai Y. Ambulatory blood pressure and 10-year risk of cardiovascular and noncardiovascular mortality: the Ohasama study. Hypertension 2005; 45: 240-245. OS

79 Verdecchia P, Porcellati C, Schillaci G, Borgioni C, Ciucci A, Battistelli M, Guerrieri M, Gatteschi C, Zampi I, Santucci A, Reboldi G. Ambulatory blood pressure. An independent predictor of prognosis in essential hypertension. Hypertension 1994, 24: 793-801. OS

80 Kawasaki T, Uezono K. An attempt for establishment ofstandard values for circadian blood pressure on the basis of clinically healthy Japanese. In: Omae T, Kawasaki T (eds). Clinical Practice of Blood Pressure Monitoring. Igaku-Shoin Ltd: Tokyo, 1993, pp 181-189 (in Japanese). GL

81 Kikuya M, Hansen TW, Thijs L, Björklund-Bodegård K, Kuznetsova T, Ohkubo T, Richart $\mathrm{T}$, Torp-Pedersen $\mathrm{C}$, Lind $\mathrm{L}$, Ibsen $\mathrm{H}$, Imai $\mathrm{Y}$, Staessen JA, International Database on Ambulatory blood pressure monitoring in relation to Cardiovascular Outcomes Investigators. Diagnostic thresholds for ambulatory blood pressure monitoring based on 10-year cardiovascular risk. Circulation 2007; 115 2145-2152. OS

82 Kikuya M, Hozawa A, Ohokubo T, Tsuji I, Michimata M, Matsubara M, Ota M, Nagai K, Araki T, Satoh $\mathrm{H}$, Ito S, Hisamichi S, Imai Y. Prognostic significance of blood pressure and heart rate variabilities: the Ohasama study. Hypertension 2000; 36 901-906. OS

83 Ugajin T, Hozawa A, Ohkubo T, Asayama K, Kikuya M, Obara T, Metoki H, Hoshi H, Hashimoto J, Totsune K, Satoh H, Tsuji I, Imai Y. White-coat hypertension as a risk factor for the development of home hypertension: the Ohasama study. Arch Intern Med 2005; 165: 1541-1546. OS

84 Verdecchia P, Reboldi GP, Angeli F, Schillaci G, Schwartz JE, Pickering TG, Imai Y, Ohkubo T, Kario K. Short- and long-term incidence of stroke in white-coat hypertension. Hypertension 2005; 45: 203-208. OS

85 Ohkubo T, Imai Y, Tsuji I, Nagai K, Watanabe N, Minami N, Kato J, Kikuchi N, Nishiyama A, Aihara A, Sekino M, Satoh H, Hisamichi S. Relation between nocturnal decline in blood pressure and mortality. The Ohasama Study. Am J Hypertens 1997; 10: 1201-1207. CT

86 Kario K, Pickering TG, Umeda Y, Hoshide S, Hoshide Y, Morinari M, Murata M, Kuroda T, Schwartz JE, Shimada K. Morning surge in blood pressure as a predictor of silent and clinical cerebrovascular disease in elderly hypertensives: a prospective study. Circulation 2003; 107: 1401-1406. OS

87 Chonan K, Hashimoto J, Ohkubo T, Tsuji I, Nagai K, Kikuya M, Hozawa A, Matsubara M, Suzuki M, Fujiwara T, Araki T, Satoh H, Hisamichi S, Imai Y. Insufficient duration of action of antihypertensive drugs mediates high blood pressure in the morning in hypertensive population: the Ohasama study. Clin Exp Hypertens 2002; 24 261-275. OS

88 Bobrie G, Chatellier G, Genes N, Clerson P, Vaur L, Vaisse B, Menard J, Mallion JM. Cardiovascular prognosis of 'masked hypertension' detected by blood pressure self-measurement in elderly treated hypertensive patients. JAMA 2004; 291 1342-1349. OS

89 Ohkubo T, Kikuya M, Metoki H, Asayama K, Obara T, Hashimoto J, Totsune K, Hoshi $\mathrm{H}$, Satoh H, Imai Y. Prognosis of 'masked' hypertension and 'white-coat' hypertension detected by 24-h ambulatory blood pressure monitoring 10-year follow-up from the Ohasama study. J Am Coll Cardiol 2005; 46: 508-515. OS

90 Harada K, Karube Y, Saruhara H, Takeda K, Kuwajima I. Workplace hypertension is associated with obesity and family history of hypertension. Hypertens Res 2006; 29 : 969-976. OS

91 Metoki H, Ohkubo T, Kikuya M, Asayama K, Obara T, Hashimoto J, Totsune K, Hoshi $\mathrm{H}$, Satoh H, Imai Y. Prognostic significance for stroke of a morning pressor surge and a nocturnal blood pressure decline: the Ohasama study. Hypertension 2006; 47: 149-154. OS

92 Kamoi K, Miyakoshi M, Soda S, Kaneko S, Nakagawa O. Usefulness of home blood pressure measurement in the morning in type 2 diabetic patients. Diabetes Care 2002; 25: 2218-2223. OS

93 Asayama K, Ohkubo T, Kikuya M, Obara T, Metoki H, Inoue R, Hara A, Hirose T, Hoshi H, Hashimoto J, Totsune K, Satoh H, Imai Y. Prediction of stroke by home 'morning' versus 'evening' blood pressure values: the Ohasama study. Hypertension 2006; 48: 737-743. OS

94 Kario K, Ishikawa J, Pickering TG, Hoshide S, Eguchi K, Morinari M, Hoshide Y, Kuroda T, Shimada K. Morning hypertension: the strongest independent risk factor for stroke in elderly hypertensive patients. Hypertens Res 2006; 29: 581-587. OS

95 Chonan K, Kikuya M, Araki T, Fujiwara T, Suzuki M, Michimata M, Hashimoto J Ohkubo T, Hozawa A, Yamamoto N, Miyawaki Y, Matsubara M, Imai Y. Device for the self-measurement of blood pressure that can monitor blood pressure during sleep. Blood Press Monit 2001; 6: 203-205. OS

96 Shimada K, Kawamoto A, Matsubayashi K, Ozawa T. Silent cerebrovascular disease in the elderly. Correlation with ambulatory pressure. Hypertension 1990; 16: 692-699. OS

97 Verdecchia P, Schillaci G, Guerrieri M, Gatteschi C, Benemio G, Boldrini F, Porcellati C. Circadian blood pressure changes and left ventricular hypertrophy in essential hypertension. Circulation 1990; 81: 528-536. OS

98 Bianchi S, Bigazzi R, Baldari G, Sgherri G, Campese VM. Diurnal variations of blood pressure and microalbuminuria in essential hypertension. Am J Hypertens 1994; 7: 23-29. OS

99 Ohkubo T, Hozawa A, Yamaguchi J, Kikuya M, Ohmori K, Michimata M, Matsubara M, Hashimoto J, Hoshi H, Araki T, Tsuji I, Satoh H, Hisamichi S, Imai Y. Prognostic significance of the nocturnal decline in blood pressure in individuals with and without high 24-h blood pressure: the Ohasama study. J Hypertens 2002; 20: 2183-2189. OS

100 Shimada K, Imai Y, Kuwajima I, Abe K. Patients characteristics and effects of the long-term acting calcium channel blocker barnidipine on circadian blood pressure changes: results of the Japanese Multicenter Study on Barnidipine with Ambulatory Blood Pressure Monitoring. Blood Press Monit 2001; 6: S25-S30. OS

101 Kario K, Matsuo T, Kobayashi H, Imiya M, Matsuo M, Shimada K. Nocturnal fall of blood pressure and silent cerebrovascular damage in elderly hypertensive patients. Advanced silent cerebrovascular damage in extreme dippers. Hypertension 1996; 27: 130-135. OS

102 Boggia J, Li Y, Thijs L, Hansen TW, Kikuya M, Björklund-Bodegård K, Richart T, Ohkubo T, Kuznetsova T, Torp-Pedersen C, Lind L, Ibsen H, Imai Y, Wang J, Sandoya E, O'Brien E, Staessen JA, International Database on Ambulatory blood pressure monitoring in relation to Cardiovascular Outcomes (IDACO) investigators. Prognostic accuracy of day versus night ambulatory blood pressure: a cohort study. Lancet 2007; 370: 1219-1229. MA

103 Kelly R, Fitchett D. Noninvasive determination of aortic input impedance and external left ventricular power output: a validation and repeatability study of a new technique. J Am Coll Cardiol 1992; 20: 952-963. OS

104 Pauca AL, O'Rourke MF, Kon ND. Prospective evaluation of a method for estimating ascending aortic pressure from the radial artery pressure waveform. Hypertension 2001; 38: 932-937. OS

105 Pauca AL, Kon ND, O'Rourke MF. The second peak of the radial artery pressure wave represents aortic systolic pressure in hypertensive and elderly patients. $\mathrm{Br} \mathrm{J}$ Anaesth 2004; 92: 651-657. OS

106 Williams B, Lacy PS, Thom SM, Cruickshank K, Stanton A, Collier D, Hughes AD, Thurston H, O'Rourke M, CAFE Investigators; Anglo-Scandinavian Cardiac Outcomes Trial Investigators; CAFE Steering Committee and Writing Committee. Differential impact of blood pressure-lowering drugs on central aortic pressure and clinical outcomes: principal results of the Conduit Artery Function Evaluation (CAFE) study. Circulation 2006; 113: 1213-1225. RT

107 Agabiti-Rosei E, Mancia G, O'Rourke MF, Roman MJ, Safar ME, Smulyan H, Wang JG, Wilkinson IB, Williams B, Vlachopoulos C. Central blood pressure measurements and antihypertensive therapy: a consensus document. Hypertension 2007; 50: 154-160. GL

108 Hashimoto J, Imai Y, O'Rourke MF. Monitoring of antihypertensive therapy for reduction in left ventricular mass. Am J Hypertens 2007; 20: 1229-1233. CT

109 Ueda K, Omae T, Hasuo Y, Kiyohara Y, Fujii I, Wada J, Kato I, Kawano H, Shinkawa A, Omura T, Fujishima M. Prognosis and outcome of elderly hypertensives in a Japanese community: results from a long-term prospective study. J Hypertens 1988; 6: 991-997. OS

110 Franklin SS, Khan SA, Wong ND, Larson MG, Levy D. Is pulse pressure useful in predicting risk for coronary heart disease? The Framingham heart study. Circulation 1999; 100: 354-360. OS

111 Kannel WB, Kannel C, Paffenbarger RS, Cupples LA. Heart rate and cardiovascular mortality: the Framingham Study. Am Heart J 1987; 113: 1489-1494. OS

112 Palatini P, Benetos A, Grassi G, Julius S, Kjeldsen SE, Mancia G, Narkiewicz K, Parati G, Pessina AC, Ruilope LM, Zanchetti A, European Society of Hypertension. Identification and management of the hypertensive patient with elevated heart rate: statement of a European Society of Hypertension Consensus Meeting. J Hypertens 2006; 24: 603-610. GL

113 Palatini P, Thijs L, Staessen JA, Fagard RH, Bulpitt CJ, Clement DL, de Leeuw PW, Jaaskivi M, Leonetti G, Nachev C, O'Brien ET, Parati G, Rodicio JL, Roman E, Sarti C, Tuomilehto J, Systolic Hypertension in Europe (Syst-Eur) Trial Investigators. Predictive value of clinic and ambulatory heart rate for mortality in elderly subjects with systolic hypertension. Arch Intern Med 2002; 162: 2313-2321. OS

114 Hozawa A, Ohkubo T, Kikuya M, Ugajin T, Yamaguchi J, Asayama K, Metoki H, Ohmori K, Hoshi H, Hashimoto J, Satoh H, Tsuji I, Imai Y. Prognostic value of home heart rate for cardiovascular mortality in the general population: the Ohasama study. $\mathrm{Am} \mathrm{J}$ Hypertens 2004; 17: 1005-1010. OS

115 Benetos A, Zureik M, Morcet J, Thomas F, Bean K, Safar M, Ducimetière P, Guize L. A decrease in diastolic blood pressure combined with an increase in systolic blood pressure is associated with a higher cardiovascular mortality in men. J Am Coll Cardiol 2000; 35: 673-680. OS

116 Staessen JA, Gasowski J, Wang JG, Thijs L, Den Hond E, Boissel JP, Coope J, Ekbom T, Gueyffier F, Liu L, Kerlikowske K, Pocock S, Fagard RH. Risks of untreated and treated isolated systolic hypertension in the elderly: meta-analysis of outcome trials. Lancet 2000; 355: 865-872. MA 
117 Darne B, Girerd X, Safar M, Cambien F, Guize L. Pulsatile versus steady component of blood pressure: a cross-sectional analysis and a prospective analysis on cardiovascular mortality. Hypertension 1989; 13: 392-400. OS

118 Benetos A, Safar M, Rudnichi A, Smulyan H, Richard JL, Ducimetieère P, Guize L. Pulse pressure: a predictor of long-term cardiovascular mortality in a French male population. Hypertension 1997; 30: 1410-1415. OS

119 Whitworth JA, World Health Organization, International Society of Hypertension Writing Group. 2003 World Health Organization (WHO) International Society of Hypertension (ISH) statement on management of hypertension. J Hypertens 2003; 21: 1983-1992. GL

120 Shimamoto K. New trends in management and treatment of hypertension (JNC-VI and the current status in Japan). Nippon Naika Gakkai Zasshi 1999; 88: 401-405. Japanese. RV

121 MacMahon S, Peto R, Cutler J, Collins R, Sorlie P, Neaton J, Abbott R, Godwin J, Dyer A, Stamler J. Blood pressure, stroke, and coronary heart disease. Part 1, prolonged differences in blood pressure: prospective observational studies corrected for the regression dilution bias. Lancet 1990; 335: 765-774. MA

122 Vasan RS, Larson MG, Leip EP, Evans JC, O'Donnell CJ, Kannel WB, Levy D. Impact of high-normal blood pressure on the risk of cardiovascular disease. N Engl J Med 2001; 345: 1291-1297. OS

123 Shimamoto K, Kita T, Mabuchi H, Matsuzaki M, Matsuzawa Y, Nakaya N, Oikawa S, Saito Y, Sasaki J, Itakura H, J-LIT Study Group. The risk of cardiovascular events in Japanese hypertensive patients with hypercholesterolemia: sub-analysis of the Japan Lipid Intervention Trial (J-LIT) Study, a large-scale observational cohort study. Hypertens Res 2005; 28: 879-887. CT

124 Vasan RS, Larson MG, Leip EP, Kannel WB, Levy D. Assessment of frequency of progression to hypertension in non-hypertensive participants in the Framingham Heart Study: a cohort study. Lancet 2001; 358: 1682-1686. OS

125 Kassai B, Gueyffier F, Boissel JP, Boutitie F, Cucherat M. Absolute benefit, number needed to treat and gain in life expectancy: which efficacy indices for measuring the treatment benefit? J Clin Epidemiol 2003; 56: 977-982.

126 Committee to Evaluate Diagnostic Standards for Metabolic Syndrome. [Definition and the diagnostic standard for metabolic syndrome]. Nippon Naika Gakkai Zasshi. 2005; 94: 794-809. Japanese. GL

127 National Kidney Foundation. Executive summary. Am J Kidney Dis 2004; 43 : s16-s33. GL

128 Arnlöv J, Evans JC, Meigs JB, Wang TJ, Fox CS, Levy D, Benjamin EJ, D’Agostino RB, Vasan RS. Low-grade albuminuria and incidence of cardiovascular disease events in nonhypertensive and nondiabetic individuals: the Framingham Heart Study. Circulation 2005; 112: 969-975. OS

129 Segura J, Ruilope LM, Zanchetti A. On the importance of estimating renal function for cardiovascular risk assessment. J Hypertens 2004; 22: 1635-1639. RV

130 Rahman M, Pressel S, Davis BR, Rahman M, Pressel S, Davis BR, Nwachuku C, Wright Jr JT, Whelton PK, Barzilay J, Batuman V, Eckfeldt JH, Farber MA, Franklin S, Henriquez M, Kopyt N, Louis GT, Saklayen M, Stanford C, Walworth C, Ward H, Wiegmann T, ALLHAT Collaborative Research Group. Cardiovascular outcomes in high-risk hypertensive patients stratified by baseline glomerular filtration rate. Ann Intern Med 2006; 144: 172-180. OS

131 Nakayama M, Metoki H, Terawaki H, Ohkubo T, Kikuya M, Sato T, Nakayama K, Asayama K, Inoue R, Hashimoto J, Totsune K, Hoshi H, Ito S, Imai Y. Kidney dysfunction as a risk factor for first symptomatic stroke events in a general Japanese population—the Ohasama study. Nephrol Dial Transplant 2007; 22 1910-1915. OS

132 Irie F, Iso H, Sairenchi T, Fukasawa N, Yamagishi K, Ikehara S, Kanashiki M, Saito Y, Ota $\mathrm{H}$, Nose $\mathrm{T}$. The relationships of proteinuria, serum creatinine, glomerular filtration rate with cardiovascular disease mortality in Japanese general population. Kidney Int 2006; 69: 1264-1271. OS

133 de Leeuw PW, Ruilope LM, Palmer CR, de Leeuw PW, Ruilope LM, Palmer CR, Brown MJ, Castaigne A, Mancia G, Rosenthal T, Wagener G. Clinical significance of renal function in hypertensive patients at high risk: results from the INSIGHT trial. Arch Intern Med 2004; 164: 2459-2464. RT

134 Turnbull F, Neal B, Algert C, Chalmers J, Chapman N, Cutler J, Woodward M, MacMahon S, Blood Pressure Lowering Treatment Trialists' Collaboration. Effects of different blood pressure-lowering regimens on major cardiovascular events in individuals with and without diabetes mellitus: results of prospectively designed overviews of randomized trials. Arch Intern Med 2005; 165: 1410-1419. MA

135 PROGRESS Collaborative Group. Randomised trial of a perindopril-based bloodpressure-lowering regimen among 6,105 individuals with previous stroke or transient ischaemic attack. Lancet 2001; 358: 1033-1041. RT

136 UK Prospective Diabetes Study Group. Tight blood pressure control and risk of macrovascular and microvascular complications in type 2 diabetes: UKPDS 38. BMJ 1998; 317: 703-713. RT

137 Fujishima M, Kiyohara Y, Kato I, Ohmura T, Iwamoto H, Nakayama K, Ohmori S, Yoshitake T. Diabetes and cardiovascular disease in a prospective population survey in Japan: The Hisayama Study. Diabetes 1996; 45: S14-S16. OS

138 An overview of dialysis treatment in Japan (as of Dec 31, 2006). J Jpn Soc Dial Ther 2008; 41: 1-28.

139 Hansson L, Zanchetti A, Carruthers SG, Dahlöf B, Elmfeldt D, Julius S, Ménard J, Rahn KH, Wedel H, Westerling S, HOT Study Group. Effects of intensive bloodpressure lowering and low-dose aspirin in patients with hypertension: principal results of the Hypertension Optimal Treatment (HOT) randomised trial. Lancet 1998; 351: 1755-1762. RT
140 Brenner BM, Cooper ME, de Zeeuw D, Keane WF, Mitch WE, Parving HH, Remuzzi G, Snapinn SM, Zhang Z, Shahinfar S, RENAAL Study Investigators. Effects of losartan on renal and cardiovascular outcomes in patients with type 2 diabetes and nephropathy. N Engl J Med 2001; 345: 861-869. RT

141 Schrier RW, Estacio RO, Esler A, Mehler P. Effects of aggressive blood pressure control in normotensive type 2 diabetic patients on albuminuria, retinopathy and strokes. Kidney Int 2002; 61: 1086-1097. RT

142 Omata K, Kanazawa M, Sato T, Abe F, Saito T, Abe K. Therapeutic advantages of angiotensin converting enzyme inhibitors in chronic renal disease. Kidney Int Suppl 1996; 55: S57-S62. CT

143 Asayama K, Ohkubo T, Satoh A, Hara A, Obara T, Yasui D, Metoki H, Inoue R, Kikuya M, Hashimoto J, Hoshi H, Satoh H, Imai Y. Proposal of a riskstratification system for the Japanese population based on blood pressure levels: the Ohasama Study. Hypertens Res 2008; 31: 1315-1322. OS

144 Rydén L, Standl E, Bartnik M, Van den Berghe G, Betteridge J, de Boer MJ, Cosentino F, Jönsson B, Laakso M, Malmberg K, Priori S, Ostergren J, Tuomilehto J, Thrainsdottir I, Vanhorebeek I, Stramba-Badiale M, Lindgren P, Qiao Q, Priori SG, Blanc JJ, Budaj A, Camm J, Dean V, Deckers J, Dickstein K, Lekakis J, McGregor K, Metra M, Morais J, Osterspey A, Tamargo J, Zamorano JL, Deckers JW, Bertrand M, Charbonnel B, Erdmann E, Ferrannini E, Flyvbjerg A, Gohlke H, Juanatey JR, Graham I, Monteiro PF, Parhofer K, Pyörälä K, Raz I, Schernthaner G, Volpe M, Wood D, Task Force on Diabetes and Cardiovascular Diseases of the European Society of Cardiology (ESC); European Association for the Study of Diabetes (EASD). Task Force on Diabetes and Cardiovascular Diseases of the European Society of Cardiology (ESC). Guidelines on diabetes, pre-diabetes, and cardiovascular diseases: executive summary. The Task Force on Diabetes and Cardiovascular Diseases of the European Society of Cardiology (ESC) and of the European Association for the Study of Diabetes (EASD). Eur Heart $J$ 2007; 28: 88-136. GL

145 Hashimoto H, Kitagawa K, Hougaku H, Shimizu Y, Sakaguchi M, Nagai Y, Iyama S, Yamanishi $\mathrm{H}$, Matsumoto M, Hori M. C-reactive protein is an independent predictor of the rate of increase in early carotid atherosclerosis. Circulation 2001; 104: 63-67. CT

146 Iwashima Y, Horio T, Kamide K, Rakugi H, Ogihara T, Kawano Y. C-reactive protein, left ventricular mass index, and risk of cardiovascular disease in essential hypertension. Hypertens Res 2007; 30: 1177-1185. CT

147 Ishikawa J, Tamura Y, Hoshide S, Eguchi K, Ishikawa S, Shimada K, Kario K. Lowgrade inflammation is a risk factor for clinical stroke events in addition to silent cerebral infarcts in Japanese older hypertensives: the Jichi Medical School ABPM Study, wave 1. Stroke 2007; 38: 911-917. RT

148 Kobayashi S, Okada K, Koide H, Bokura H, Yamaguchi S. Subcortical silent brain infarction as a risk factor for clinical stroke. Stroke 1997; 28: 1932-1939.

149 Kario K, Shimada K, Schwartz JE, Matsuo T, Hoshide S, Pickering TG. Silent and clinically overt stroke in older Japanese subjects with white-coat and sustained hypertension. J Am Coll Cardiol 2001; 38: 238-245. OS

150 Vermeer SE, Hollander M, van Dijk EJ, Hofman A, Koudstaal PJ, Breteler MM, Rotterdam Scan Study. Silent brain infarcts and white matter lesions increase stroke risk in the general population: the Rotterdam Scan Study. Stroke 2003; 34: 1126-1129. OS

151 Naka H, Nomura E, Takahashi T, Wakabayashi S, Mimori Y, Kajikawa H, Kohriyama T, Matsumoto M. Combinations of the presence or absence of cerebral microbleeds and advanced white matter hyperintensity as predictors of subsequent stroke types. AJNR Am J Neuroradiol 2006; 27: 830-835. OS

152 Gauthier S, Reisberg B, Zaudig M, Petersen RC, Ritchie K, Broich K, Belleville S, Brodaty $\mathrm{H}$, Bennett $\mathrm{D}$, Chertkow $\mathrm{H}$, Cummings JL, de Leon M, Feldman H, Ganguli M, Hampel H, Scheltens P, Tierney MC, Whitehouse P, Winblad B, International Psychogeriatric Association Expert Conference on mild cognitive impairment. Mild cognitive impairment. Lancet 2006; 367: 1262-1270. RV

153 Cooper LS, Wong TY, Klein R, Cooper LS, Wong TY, Klein R, Sharrett AR, Bryan RN, Hubbard LD, Couper DJ, Heiss G, Sorlie PD. Retinal microvascular abnormalities and MRI-defined subclinical cerebral infarction: the Atherosclerosis Risk in Communities Study. Stroke 2006; 37: 82-86. OS

154 Salles G, Cardoso C, Nogueira AR, Bloch K, Muxfeldt E. Importance of the electrocardiographic strain pattern in patients with resistant hypertension. Hypertension 2006; 48: 437-442.

155 Okin PM, Devereux RB, Jern S, Okin PM, Devereux RB, Jern S, Kjeldsen SE, Julius S, Nieminen MS, Snapinn S, Harris KE, Aurup P, Edelman JM, Wedel H, Lindholm LH, Dahlöf B, LIFE Study Investigators. Regression of electrocardiographic left ventricular hypertrophy during antihypertensive treatment and the prediction of major cardiovascular events. JAMA 2004; 292: 2343-2349. OS

156 Watanabe H, Tanabe N, Watanabe T, Darbar D, Roden DM, Sasaki S, Aizawa Y. Metabolic syndrome and risk of development of atrial fibrillation: the Niigata preventive medicine study. Circulation 2008; 117: 1255-1260. OS

157 Muiesan ML, Salvetti M, Monteduro C, Bonzi B, Paini A, Viola S, Poisa P, Rizzoni D, Castellano M, Agabiti-Rosei E. Left ventricular concentric geometry during treatment adversely affects cardiovascular prognosis in hypertensive patients. Hypertension 2004; 43: 731-738. OS

158 Eguchi K, Kario K, Hoshide S, Ishikawa J, Morinari M, Shimada K. Type 2 diabetes is associated with left ventricular concentric remodeling in hypertensive patients. Am J Hypertens 2005; 18: 23-29. OS

159 Sudoh T, Kangawa K, Minamino N, Matsuo H. A new natriuretic peptide in porcine brain. Nature 1988; 332: 78-81. OS

160 Sarnak MJ, Levey AS, Schoolwerth AC, Coresh J, Culleton B, Hamm LL, McCullough PA, Kasiske BL, Kelepouris E, Klag MJ, Parfrey P, Pfeffer M, Raij L, Spinosa DJ, 
Wilson PW, American Heart Association Councils on Kidney in Cardiovascular Disease, High Blood Pressure Research, Clinical Cardiology, and Epidemiology and Prevention. Kidney disease as a risk factor for development of cardiovascular disease: a statement from the American Heart Association Councils on Kidney in Cardiovascular Disease, High Blood Pressure Research, Clinical Cardiology, and Epidemiology and Prevention. Circulation 2003; 108: 2154-2169. GL

161 Iseki K, Ikemiya Y, Iseki C, Takishita S. Proteinuria and the risk of developing endstage renal disease. Kidney Int 2003; 63: 1468-1474.

162 Matsuo S, Imai E, Horio Y, Yosuda Y, Tomita K, Nitta K, Yamagata K, Tomino Y, Yokoyama $\mathrm{H}$, Hishida $\mathrm{A}$, on behalf of the collaborators for developing Japanese equation for estimating GFR. The Japanese equations for estimating glomerular filtration rate from serum creatinine (Submitted, unpublished) OS.

163 Gerber LM, Schwartz JE, Pickering TG. Albumin-to-creatinine ratio predicts change in ambulatory blood pressure in normotensive persons: a 7.5-year prospective study. $\mathrm{Am}$ $J$ Hypertens 2006; 19: 220-226. OS

164 Ibsen $\mathrm{H}$, Olsen MH, Wachtell K, Borch-Johnsen K, Lindholm LH, Mogensen CE, Dahlöf B, Devereux RB, de Faire U, Fyhrquist F, Julius S, Kjeldsen SE, LederballePedersen $\mathrm{O}$, Nieminen MS, Omvik P, Oparil S, Wan Y. Reduction in albuminuria translates to reduction in cardiovascular events in hypertensive patients: losartan intervention for endpoint reduction in hypertension study. Hypertension 2005; 45 198-202. OS

165 The Joint Committee of 'The Japan Academy of Neurosonology' and 'The Japan Society of Embolus Detection and Treatment' on Guideline for Nuerosonology (Carotid Ultrasound Examination). Neurosonology 2006; 19: 50. Japanese. GL

166 Nagai Y, Matsumoto M, Metter EJ. The carotid artery as a noninvasive window for cardiovascular risk in apparently healthy individuals. Ultrasound Med Biol 2002; 28: 1231-1238. RV

167 Takiuchi S, Rakugi H, Honda K, Masuyama T, Hirata N, Ito H, Sugimoto K, Yanagitani Y, Moriguchi K, Okamura A, Higaki J, Ogihara T. Quantitative ultrasonic tissue characterization can identify high-risk atherosclerotic alteration in human carotid arteries. Circulation 2000; 102: 766-770.

168 Murabito JM, Evans JC, Larson MG, Nieto K, Levy D, Wilson PW, Framingham Study. The ankle-brachial index in the elderly and risk of stroke, coronary disease, and death: the Framingham Study. Arch Intern Med 2003; 163: 1939-1942. OS

169 Yamashina A, Tomiyama H, Takeda K, Tsuda H, Arai T, Hirose K, Koji Y, Hori S, Yamamoto $Y$. Validity, reproducibility, and clinical significance of noninvasive brachialankle pulse wave velocity measurement. Hypertens Res 2002; 25: 359-364.

170 Tomiyama H, Hashimoto H, Hirayama Y, Yambe M, Yamada J, Koji Y, Shiina K, Yamamoto $Y$, Yamashina A. Synergistic acceleration of arterial stiffening in the presence of raised blood pressure and raised plasma glucose. Hypertension 2006; 47: $180-188$.

171 Munakata M, Nunokawa T, Yoshinaga K, Toyota T, J-TOPP Study Group. Brachialankle pulse wave velocity is an independent risk factor for microalbuminuria in patients with essential hypertension - a Japanese trial on the prognostic implication of pulse wave velocity (J-TOPP). Hypertens Res 2006; 29: 515-521. OS

172 Yambe M, Tomiyama H, Yamada J, Koji Y, Motobe K, Shiina K, Yamamoto Y, Yamashina A. Arterial stiffness and progression to hypertension in Japanese male subjects with high normal blood pressure. J Hypertens 2007; 25: 87-93. OS

173 Takazawa K, Kobayashi H, Shindo N, Tanaka N, Yamashina A. Relationship between radial and central arterial pulse wave and evaluation of central aortic pressure using the radial arterial pulse wave. Hypertens Res 2007; 30: 219-228. CT

174 Rose KM, Eigenbrodt ML, Biga RL, Couper DJ, Light KC, Sharrett AR, Heiss G. Orthostatic hypotension predicts mortality in middle-aged adults: the Atherosclerosis Risk In Communities (ARIC) Study. Circulation 2006; 114: 630-636. OS

175 Kario K, Eguchi K, Hoshide S, Hoshide Y, Umeda Y, Mitsuhashi T, Shimada K. U-curve relationship between orthostatic blood pressure change and silent cerebrovascular disease in elderly hypertensives: orthostatic hypertension as a new cardiovascular risk factor. J Am Coll Cardiol 2002; 40: 133-141. OS

176 Kario K, Shimada K, Pickering TG. Abnormal nocturnal blood pressure falls in elderly hypertension: clinical significance and determinants. J Cardiovasc Pharmacol 2003 41 (Suppl 1): S61-S66. OS

177 Kohara K, Tabara Y, Yamamoto Y, Miki T. Orthostatic hypertension: another orthostatic disorder to be aware of. J Am Geriatr Soc 2000; 48: 1538-1539.

178 Lever AF, Ramsay LE. Treatment of hypertension in the elderly. J Hypertens 1995; 13 : 571-579. OS

179 Whelton PK, He J. Blood pressure reduction. In: Hennekens CH (ed). Clinical Trials in Cardiovascular Disease: A Companion to Braunwald's Heart Disease. WB Saunders Co.: Philadelphia, 1999, pp 341-359.

180 Gueyffier F, Boutitie F, Boissel JP, Pocock S, Coope J, Cutler J, Ekbom T, Fagard R, Friedman L, Perry M, Prineas R, Schron E, The INDANA Investigators. Effect of antihypertensive drug treatment on cardiovascular outcomes in women and men. A meta-analysis of individual patient data from randomized, controlled trials. Ann Intern Med 1997; 126: 761-767. MA

181 MacMahon S, Rodgers A. The effects of blood pressure reduction in older patients: an overview of five randomized controlled trials in elderly hypertensives. Clin Exp Hypertens 1993; 15: 967-978. MA

182 Beckett NS, Peters R, Fletcher AE, Staessen JA, Liu L, Dumitrascu D, Stoyanovsky V, Antikainen RL, Nikitin Y, Anderson C, Belhani A, Forette F, Rajkumar C, Thijs L, Banya W, Bulpitt CJ, HYVET Study Group. Treatment of hypertension in patients 80 years of age or older. N Engl J Med 2008; 358: 1887-1898. RT

183 Takagi S, Saitoh S, Nakano M, Hayashi Y, Obara F, Onishi H, Shimamoto K. Relationship between blood pressure level and mortality rate: an 18-year study conducted in two rural communities in Japan. J Hypertens 2000; 18: 139-144. OS
184 Liu L, Zhang Y, Liu G, Li W, Zhang X, Zanchetti A, FEVER Study Group. The Felodipine Event Reduction (FEVER) Study: a randomized long-term placebo-controlled trial in Chinese hypertensive patients. J Hypertens 2005; 23: 2157-2172. RT

185 Arima H, Chalmers J, Woodward M, Anderson C, Rodgers A, Davis S, Macmahon S, Neal B, PROGRESS Collaborative Group. Lower target blood pressures are safe and effective for the prevention of recurrent stroke: the PROGRESS trial. J Hypertens 2006; 24: 1201-1208. OS

186 Fox KM, EURopean trial On reduction of cardiac events with Perindopril in stable coronary Artery disease Investigators. Efficacy of perindopril in reduction of cardiovascular events among patients with stable coronary artery disease: randomised, double-blind, placebo-controlled, multicentre trial (the EUROPA study). Lancet 2003; 362: 782-788. RT

187 Lubsen J, Wagener G, Kirwan BA, de Brouwer S, Poole-Wilson PA, ACTION (A Coronary disease Trial Investigating Outcome with Nifedipine GITS) investigators. Effect of long-acting nifedipine on mortality and cardiovascular morbidity in patients with symptomatic stable angina and hypertension: the ACTION trial. J Hypertens 2005; 23: 641-648. CT

188 Nissen SE, Tuzcu EM, Libby P, Thompson PD, Ghali M, Garza D, Berman L, Shi H, Buebendorf E, Topol EJ, CAMELOT Investigators. Effect of antihypertensive agents on cardiovascular events in patients with coronary disease and normal blood pressure: the CAMELOT study: a randomized controlled trial. JAMA 2004; 292: 2217-2225. RT

189 Appel LJ, Moore TJ, Obarzanek E, Vollmer WM, Svetkey LP, Sacks FM, Bray GA, Vogt TM, Cutler JA, Windhauser MM, Lin PH, Karanja N, DASH Collaborative Research Group. A clinical trial of the effects of dietary patterns on blood pressure. $N$ Engl J Med 1997; 336: 1117-1124. RT

190 Whelton PK, Appel LJ, Espeland MA, Applegate WB, Ettinger Jr WH, Kostis JB, Kumanyika S, Lacy CR, Johnson KC, Folmar S, Cutler JA, TONE Collaborative Research Group. Sodium reduction and weight loss in the treatment of hypertension in older persons: a randomized controlled trial of nonpharmacologic interventions in the elderly (TONE). JAMA 1998; 279: 839-846. RT

191 Hayashi T, Tsumura K, Suematsu C, Okada K, Fujii S, Endo G. Walking to work and the risk for hypertension in men: the Osaka Health Survey. Ann Intern Med 1999; 131: 21-26. OS

192 Neaton JD, Grimm RH, Prineas RJ, Stamler J, Grandits GA, Elmer PJ, Cutler JA, Flack JM, Schoenberger JA, McDonald R and Treatment of Mild Hypertension Study Research Group. Treatment of Mild Hypertension Study. Final results. JAMA 1993; 270: 713-724. RT

193 Singer DR, Markandu ND, Cappuccio FP, Miller MA, Sagnella GA, MacGregor GA. Reduction of salt intake during converting enzyme inhibitor treatment compared with addition of a thiazide. Hypertension 1995; 25: 1042-1044. RT

194 Mochizuki S, Dahlöf B, Shimizu M, Ikewaki K, Yoshikawa M, Taniguchi I, Ohta M, Yamada T, Ogawa K, Kanae K, Kawai M, Seki S, Okazaki F, Taniguchi M, Yoshida S, Tajima N, Jikei Heart Study group. Valsartan in a Japanese population with hypertension and other cardiovascular disease (Jikei Heart Study): a randomised, open-label, blinded endpoint morbidity-mortality study. Lancet 2007; 369: 1431-1439. RT

195 Ogihara T, Nakao K, Fukui T, Fukiyama K, Ueshima K, Oba K, Sato T, Saruta T, Candesartan Antihypertensive Survival Evaluation in Japan Trial Group. Effects of candesartan compared with amlodipine in hypertensive patients with high cardiovascular risks: candesartan antihypertensive survival evaluation in Japan trial. Hypertension 2008; 51: 393-398. RT

196 Dahlöf B, Devereux RB, Kjeldsen SE, Julius S, Beevers G, de Faire U, Fyhrquist F, Ibsen H, Kristiansson K, Lederballe-Pedersen O, Lindholm LH, Nieminen MS, Omvik P, Oparil S, Wedel H, LIFE Study Group. Cardiovascular morbidity and mortality in the Losartan Intervention For Endpoint reduction in hypertension study (LIFE): a randomised trial against atenolol. Lancet 2002; 359: 995-1003. RT

197 Dahlöf B, Sever PS, Poulter NR, Wedel H, Beevers DG, Caulfield M, Collins R, Kjeldsen SE, Kristinsson A, Mclnnes GT, Mehlsen J, Nieminen M, O'Brien E, Ostergren J, ASCOT Investigators. Prevention of cardiovascular events with an antihypertensive regimen of amlodipine adding perindopril as required versus atenolol adding bendroflumethiazide as required, in the Anglo-Scandinavian Cardiac Outcomes Trial-Blood Pressure Lowering Arm (ASCOT-BPLA): a multicentre randomised controlled trial. Lancet 366, 895-906. RT

198 Julius S, Kjeldsen SE, Weber M, Brunner HR, Ekman S, Hansson L, Hua T, Laragh J, McInnes GT, Mitchell L, Plat F, Schork A, Smith B, Zanchetti A, VALUE trial group. Outcomes in hypertensive patients at high cardiovascular risk treated with regimens based on valsartan or amlodipine: the VALUE randomised trial. Lancet 2004; 363: 2022-2031. RT

199 Weber MA, Julius S, Kjeldsen SE, Brunner HR, Ekman S, Hansson L, Hua T, Laragh $\mathrm{JH}$, McInnes GT, Mitchell L, Plat F, Schork MA, Smith B, Zanchetti A. Blood pressure dependent and independent effects of antihypertensive treatment on clinical events in the VALUE Trial. Lancet 2004; 363: 2049-2051. CT

200 Wing LM, Brown MA, Beilin LJ, Ryan P, Reid CM, ANBP2 Management Committee and Investigators. Second Autralian National Blood Pressure Study. 'Reverse whitecoat hypertension' in older hypertensives. J Hypertens 2002; 20: 639-644. OS

201 Elliott WJ, Meyer PM. Incident diabetes in clinical trials of antihypertensive drugs: a networkmetaanalysis. Lancet 2007; 369: 201-207. MA

202 Saito I, Saruta T. Effect of education through a periodic newsletter on persistence with antihypertensive therapy. Hypertens Res 2003; 26: 159-162. CT

203 Yoshida K, Matsuoka H, Omae T, Fujii J. Patient-hospital relationship and quality of life in elderly patients with hypertension. Hypertens Res 1995; 18: 77-83. OS

204 Kaplan NM. Anxiety-induced hyperventilation. A common cause of symptoms in patients with hypertension. Arch Intern Med 1997; 157: 945-948. 
205 Mena-Martin FJ, Martin-Escudero JC, Simal-Blanco F, Carretero-Ares JL, Arzua-Mouronte D, Herreros-Fernandez V. Health-related quality of life of subjects with known and unknown hypertension: results from the population-based Hortega study. J Hypertens 2003; 21: 1283-1289. OS

206 Dimenäs ES, Wiklund IK, Dahlöf CG, Lindvall KG, Olofsson BK, De Faire UH. Differences in the subjective well-being and symptoms of normotensives, borderline hypertensives and hypertensives. J Hypertens 1989; 7: 885-890.

207 Mikami H, Ogihara T. Quality of life in the pharmacologically treated elderly patients. Nippon Ronen Igakkai Zasshi 1999; 36: 186-190. Japanese.

208 Croog SH, Levine S, Testa MA, Brown B, Bulpitt CJ, Jenkins CD, Klerman GL, Williams $\mathrm{GH}$. The effects of antihypertensive therapy on the quality of life. N Eng/ J Med 1986; 314: 1657-1664. RT

209 Grimm Jr RH, Grandits GA, Cutler JA, Stewart AL, McDonald RH, Svendsen K, Prineas RJ, Liebson PR. Relationships of quality-of-life measures to long-term lifestyle and drug treatment in the Treatment of Mild Hypertension Study. Arch Intern Med 1997; 157: 638-648. RT

210 Degl'Innocenti A, Elmfeldt D, Hofman A, Lithell H, Olofsson B, Skoog I, Trenkwalder $P$, Zanchetti A, Wiklund I. Health-related quality of life during treatment of elderly patients with hypertension: results from the Study on COgnition and Prognosis in the Elderly (SCOPE). J Hum Hypertens 2004; 18: 239-245. RT

211 Bane C, Hughes CM, Cupples ME, McElnay JC. The journey to concordance for patients with hypertension: a qualitative study in primary care. Pharm World Sci 2007; 29: 534-540.

212 Saito I. Gap between untreated, treated patients' and physicians' attitudes and awareness toward hypertension and its complications, cardiovascular diseases. Prog Med 2008; 28: 1215-1222. Japanese.

213 Roumie CL, Elasy TA, Greevy R, Griffin MR, Liu X, Stone WJ, Wallston KA, Dittus RS, Alvarez V, Cobb J, Speroff T. Improving blood pressure control through provider education, provider alerts, and patient education: a cluster randomized trial. Ann Intern Med 2006; 145: 165-175. RT

214 Lee JK, Grace KA, Taylor AJ. Effect of a pharmacy care program on medication adherence and persistence, blood pressure, and low-density lipoprotein cholesterol: a randomized controlled trial. JAMA 2006; 296: 2563-2571. RT

215 Saito I. Medication compliance and blood pressure control: the effect of number of antihypertensive drugs on medication compliance. Ketsuatsu 2006; 13: 1019-1025. Japanese.

216 Schroeder K, Fahey T, Ebrahim S. How can we improve adherence to blood pressurelowering medication in ambulatory care? Systematic review of randomized controlled trials. Arch Intern Med 2004; 164: 722-732. RV

217 Bangalore S, Kamalakkannan G, Parkar S, Messerli FH. Fixed-dose combinations improve medication compliance: a meta-analysis. Am J Med 2007; 120: 713-719. $\mathrm{MA}$

218 Jönsson B, Carides GW, Burke TA, Dasbach EJ, Lindholm LH, Dahlöf B, LIFE Study Group. Cost effectiveness of losartan in patients with hypertension and LVH: an economic evaluation for Sweden of the LIFE trial. J Hypertens 2005; 23: 1425-1431. OS

219 Saito I, Fujikawa K, Saruta T, ADVANCE-Combi Study Group. Cost-effectiveness analysis: controlled release nifedipine and valsartan combination therapy in patients with essential hypertension: the adalat CR and valsartan cost-effectiveness combination (ADVANCE-Combi) study. Hypertens Res 2008; 31: 1399-1405. OS

220 Barzilay JI, Davis BR, Cutler JA, Pressel SL, Whelton PK, Basile J, Margolis KL, Ong ST, Sadler LS, Summerson J, ALLHAT Collaborative Research Group. Fasting glucose levels and incident diabetes mellitus in older nondiabetic adults randomized to receive 3 different classes of antihypertensive treatment: a report from the Antihypertensive and Lipid-Lowering Treatment to Prevent Heart Attack Trial (ALLHAT). Arch Intern Med 2006; 166: 2191-2201. RT

221 Saito I, Kobatashi M, Saruta T. Economic analysis of antihypertensive agents in treating patients with essential hypertension. Rinsho lyaku 2003; 19: 777-788. Japanese.

222 Heidenreich PA, Davis BR, Cutler JA, Furberg CD, Lairson DR, Shlipak MG, Pressel SL, Nwachuku C, Goldman L. Cost-effectiveness of chlorthalidone, amlodipine, and lisinopril as first-step treatment for patients with hypertension: an analysis of the Antihypertensive and Lipid-Lowering Treatment to Prevent Heart Attack Trial (ALLHAT). J Gen Intern Med 2008; 23: 509-516. RT

223 Saito I, Kobayashi M, Matsushita Y, Saruta T. Pharmacoeconomical evaluation of combination therapy for lifetime hypertension treatment in Japan. Jpn Med Assoc J 2005; 48: 574-585.

224 Kawano Y, Ando K, Matsuura H, Tsuchihashi T, Fujita T, Ueshima H, Working Group for Dietary Salt Reduction of the Japanese Society of Hypertension. Report of the Working Group for Dietary Salt Reduction of the Japanese Society of Hypertension: (1) rationale for salt restriction and salt-restriction target level for the management of hypertension. Hypertens Res 2007; 30: 879-886. GL

$225 \mathrm{He}$ FJ, MacGregor GA. Effect of modest salt reduction on blood pressure: a metaanalysis of randomized trials. Implications for public health. J Hum Hypertens 2002; 16: 761-770. MA

226 The working group for dietary salt reduction of the Japanese Society of Hypertension. Low-salt $(6 \mathrm{~g} /$ day) diet recipe for the patients with hypertension. Jananese Society of Hypertension: Tokyo, 2006. GL

227 Lichtenstein AH, Appel LJ, Brands M, Carnethon M, Daniels S, Franch HA, Franklin B, Kris-Etherton P, Harris WS, Howard B, Karanja N, Lefevre M, Rudel L, Sacks F, Van Horn L, Winston M, Wylie-Rosett J, American Heart Association Nutrition Committee. Diet and lifestyle recommendations revision 2006: a scientific statement from the American Heart Association Nutrition Committee. Circulation 2006; 114: 82-96. GL
228 Appel LJ, Brands MW, Daniels SR, Karanja N, Elmer PJ, Sacks FM, American Heart Association. Dietary approaches to prevent and treat hypertension: a scientific statement from the American Heart Association. Hypertension 2006; 47: 296-308. $\mathrm{GL}$

229 Ohta Y, Tsuchihashi T, Ueno M, Kajioka T, Onaka U, Tominaga M, Eto K. Relationship between the awareness of salt restriction and the actual salt intake in hypertensive patients. Hypertens Res 2004; 27: 243-246.

230 Cook NR, Cutler JA, Obarzanek E, Buring JE, Rexrode KM, Kumanyika SK, Appel LJ, Whelton PK. Long term effects of dietary sodium reduction on cardiovascular disease outcomes: observational follow-up of the trials of hypertension prevention (TOHP). BMJ 2007; 334: 885. MA

231 Kawano Y, Tsuchihashi T, Matsuura H, Ando K, Fujita T, Ueshima H, Working Group for Dietary Salt Reduction of the Japanese Society of Hypertension. Report of the Working Group for Dietary Salt Reduction of the Japanese Society of Hypertension: (2) assessment of salt intake in the management of hypertension. Hypertens Res 2007; 30: 887-893.

232 Geleijnse JM, Hofman A, Witteman JC, Hazebroek AA, Valkenburg HA, Grobbee DE. Long-term effects of neonatal sodium restriction on blood pressure. Hypertension 1997; 29: 913-917. RT

233 Japanese Food Guide Spinning Top. Decided by Ministry of Health, Labour and Welfare and Ministry of Agriculture, Forestry and Fisheries. Dai-Ichi Shuppan Publishing: Tokyo, 2005. GL

234 Azadbakht L, Mirmiran P, Esmaillzadeh A, Azizi T, Azizi F. Beneficial effects of a Dietary Approaches to Stop Hypertension eating plan on features of the metabolic syndrome. Diabetes Care 2005; 28: 2823-2831. RT

235 Ueshima H, Stamler J, Elliott P, Chan Q, Brown IJ, Carnethon MR, Daviglus ML, He K, Moag-Stahlberg A, Rodriguez BL, Steffen LM, Van Horn L, Yarnell J, Zhou B, INTERMAP Research Group. Food omega-3 fatty acid intake of individuals (total, linolenic acid, long-chain) and their blood pressure: INTERMAP study. Hypertension 2007; 50: 313-319. OS

236 Geleijnse JM, Giltay EJ, Grobbee DE, Donders AR, Kok FJ. Blood pressure response to fish oil supplementation: metaregression analysis of randomized trials. J Hypertens 2002; 20: 1493-1499. MA

237 Iso H, Kobayashi M, Ishihara J, Sasaki S, Okada K, Kita Y, Kokubo Y, Tsugane S, JPHC Study Group. Intake of fish and n3 fatty acids and risk of coronary heart disease among Japanese: the Japan Public Health Center-Based (JPHC) Study Cohort I. Circulation 2006; 113: 195-202. OS

238 Fox CS, Massaro JM, Hoffmann U, Pou KM, Maurovich-Horvat P, Liu CY, Vasan RS, Murabito JM, Meigs JB, Cupples LA, D'Agostino Sr RB, O'Donnell CJ. Abdominal visceral and subcutaneous adipose tissue compartments: association with metabolic risk factors in the Framingham Heart Study. Circulation 2007; 116: 39-48. OS

239 Neter JE, Stam BE, Kok FJ, Grobbee DE, Geleijnse JM. Influence of weight reduction on blood pressure: a meta-analysis of randomized controlled trials. Hypertension 2003; 42: 878-884. MA

240 Dickinson HO, Mason JM, Nicolson DJ, Campbell F, Beyer FR, Cook JV, Williams B, Ford GA. Lifestyle interventions to reduce raised blood pressure: a systematic review of randomized controlled trials. J Hypertens 2006; 24: 215-233. MA

241 Haskell WL, Lee IM, Pate RR, Powell KE, Blair SN, Franklin BA, Macera CA, Heath GW, Thompson PD, Bauman A, American College of Sports Medicine, American Heart Association. Physical activity and public health: updated recommendation for adults from the American College of Sports Medicine and the American Heart Association. Circulation 2007; 116: 1081-1093. GL

242 Tashiro E, Miura S, Koga M, Sasaguri M, Ideishi M, Ikeda M, Tanaka H, Shindo M, Arakawa K. Crossover comparison between the depressor effects of low and high work-rate exercise in mild hypertension. Clin Exp Pharmacol Physiol 1993; 20: 689-696. RT

243 Shaper AG, Wannamethee G, Walker M. Physical activity, hypertension and risk of heart attack in men without evidence of ischaemic heart disease. J Hum Hypertens 1994; 8: 3-10.

244 Ohkubo T, Hozawa A, Nagatomi R, Fujita K, Sauvaget C, Watanabe Y, Anzai Y, Tamagawa A, Tsuji I, Imai Y, Ohmori H, Hisamichi S. Effects of exercise training on home blood pressure values in older adults: a randomized controlled trial. J Hypertens 2001; 19: 1045-1052. RT

245 Nakamura K, Okamura T, Hayakawa T, Hozawa A, Kadowaki T, Murakami Y, Kita Y, Okayama A, Ueshima H, NIPPON DATA90 Research Group. The proportion of individuals with alcohol-induced hypertension among total hypertensives in a general Japanese population: NIPPON DATA90. Hypertens Res 2007; 30: 663-668. OS

246 Kloner RA, Rezkalla SH. To drink or not to drink? That is the question. Circulation 2007; 116: 1306-1317. RV

247 Xin X, He J, Frontini MG, Ogden LG, Motsamai Ol, Whelton PK. Effects of alcohol reduction on blood pressure: a meta-analysis of randomized controlled trials. Hypertension 2001; 38: 1112-1117. MA

248 Groppelli A, Giorgi DM, Omboni S, Parati G, Mancia G. Persistent blood pressure increase induced by heavy smoking. J Hypertens 1992; 10: 495-499.

249 Minami J, Ishimitsu T, Matsuoka H. Effects of smoking cessation on blood pressure and heart rate variability in habitual smokers. Hypertension 1999; 33 : 586-590. RT

250 Pickering TG, , Eguchi K, Kario K. Masked hypertension: a review. Hypertens Res 2007; 30: 479-488. RV

251 Miyatake N, Wada J, Kawasaki Y, Nishii K, Makino H, Numata T. Relationship between metabolic syndrome and cigarette smoking in the Japanese population. Intern Med 2006; 45: 1039-1043. OS 
252 The Eurowinter Group. Cold exposure and winter mortality from ischaemic heart disease, cerebrovascular disease, respiratory disease, and all causes in warm and cold regions of Europe. Lancet 1997; 349: 1341-1346. OS

253 Espeland MA, Whelton PK, Kostis JB, Bahnson JL, Ettinger WH, Cutler JA, Appel LJ, Kumanyika S, Farmer D, Elam J, Wilson AC, Applegate WB, TONE Cooperative Research Group. Predictors and mediators of successful long-term withdrawal from antihypertensive medications. Trial of Nonpharmacologic Interventions in the Elderly. Arch Fam Med 8: 228-236. RT

254 Appel LJ, Champagne CM, Harsha DW, Cooper LS, Obarzanek E, Elmer PJ, Stevens VJ, Vollmer WM, Lin PH, Svetkey LP, Stedman SW, Young DR, Writing Group of the PREMIER Collaborative Research Group. Effects of comprehensive lifestyle modification on blood pressure control: main results of the PREMIER clinical trial. JAMA 289: 2083-2093. RT

255 Turnbull F, Blood Pressure Lowering Treatment Trialists' Collaboration. Effects of different blood-pressure-lowering regimens on major cardiovascular events: results of prospectively-designed overviews of randomised trials. Lancet 2003; 362 . 1527-1535. MA

256 Turnbull F, Neal B, Pfeffer M, Kostis J, Algert C, Woodward M, Chalmers J, Zanchetti A, MacMahon S, Blood Pressure Lowering Treatment Trialists' Collaboration. Blood pressure-dependent and independent effects of agents that inhibit the renin-angiotensin system. J Hypertens 2007; 25: 951-958. MA

257 William B, Poulter NR, Brown MJ. British Hypertension Society. British Hypertension Society guidelines (BHS-IV). J Fam Pract 2004; 53: 528-550. GL

258 Morgan TO, Anderson Al, Maclnnis RJ. ACE inhibitors, beta-blockers, calcium blockers, and diuretics for the control of systolic hypertension. Am J Hypertens 2001; 14: 241-247. RV

259 Hansson L, Lindholm LH, Ekbom T, Dahlöf B, Lanke J, Scherstén B, Wester PO, Hedner T, de Faire U. Randomised trial of old and new antihypertensive drugs in elderly patients: cardiovascular mortality and morbidity the Swedish Trial in Old Patients with Hypertension-2 study. Lancet 1999; 354: 1751-1756. RT

260 Ohkubo T, Obara T, Funahashi J, Kikuya M, Asayama K, Metoki H, Oikawa T, Takahashi H, Hashimoto J, Totsune K, Imai Y, J-HOME Study Group. Control of blood pressure as measured at home and office, and comparison with physicians' assessment of control among treated hypertensive patients in Japan: First Report of the Japan Home versus Office Blood Pressure Measurement Evaluation (J-HOME) study. Hypertens Res 2004; 27: 755-763. OS

261 Mahmud A, Feely J. Low-dose quadruple antihypertensive combination: more efficacious than individual agents-a preliminary report. Hypertension 2007; 49: 272-275. RT

262 Law MR, Wald NJ, Morris JK, Jordan RE. Value of low dose combination treatment with blood pressure lowering drugs: analysis of 354 randomised trials. BMJ 2003; 326: 1427. MA

263 Hermida RC, Ayala DE, Calvo C, López JE, Mojón A, Fontao MJ, Soler R, Fernández $J R$. Effects of time of day of treatment on ambulatory blood pressure pattern of patients with resistant hypertension. Hypertension 2005; 46: 1053-1059.

264 Elliott WJ. Drug interactions and drugs that affect blood pressure. J Clin Hypertens (Greenwich) 2006; 8: 731-737. RV

265 Sugiyama T, Kiraku J, Ashida T, Fujii J. Remission of hypertension: retrospective observations over a period of 20 years. Hypertens Res 1998; 21: 103-108.

266 Terpstra WF, May JF, Smit AJ, de Graeff PA, Havinga TK, van den Veur E, Schuurman $\mathrm{FH}$, Meyboom-de Jong B, Crijns HJ. Long-term effects of amlodipine and lisinopril on left ventricular mass and diastolic function in elderly, previously untreated hypertensive patients: the ELVERA trial. J Hypertens 2001; 19: 303-309. RT

267 Sipahi I, Tuzcu EM, Schoenhagen P, Wolski KE, Nicholls SJ, Balog C, Crowe TD, Nissen SE. Effects of normal, pre-hypertensive, and hypertensive blood pressure levels on progression of coronary atherosclerosis. J Am Coll Cardiol 2006; 48: 833-838. CT

268 Fujita T, Ando K, Nishimura H, Ideura T, Yasuda G, Isshiki M, Takahashi K, Cilnidipine versus Amlodipine Randomised Trial for Evaluation in Renal Desease(CARTER) Study Investigators. Antiproteinuric effect of the calcium channel blocker cilnidipine added to renin-angiotensin inhibition in hypertensive patients with chronic renal disease. Kidney Int 2007; 72: 1543-1549. RT

269 Ishimitsu T, Kameda T, Akashiba A, Takahashi T, Ohta S, Yoshii M, Minami J, Ono H, Numabe A, Matsuoka H. Efonidipine reduces proteinuria and plasma aldosterone in patients with chronic glomerulonephritis. Hypertens Res 2007; 30: 621-626. RT

270 Nakamura T, Sugaya T, Kawagoe Y, Suzuki T, Ueda Y, Koide H, Inoue T, Node K. Azelnidipine reduces urinary protein excretion and urinary liver-type fatty acid binding protein in patients with hypertensive chronic kidney disease. Am J Med Sci 2007 ; 333: 321-326. RT

271 Ohishi M, Takagi T, Ito N, Terai M, Tatara Y, Hayashi N, Shiota A, Katsuya T, Rakugi H, Ogihara T. Renal-protective effect of T- and L-type calcium channel blockers in hypertensive patients: an Amlodipine-to-Benidipine Changeover (ABC) study. Hypertens Res 2007; 30: 797-806. CT

272 Zou Y, Akazawa H, Qin Y, Sano M, Takano H, Minamino T, Makita N, Iwanaga K, Zhu W, Kudoh S, Toko H, Tamura K, Kihara M, Nagai T, Fukamizu A, Umemura S, liri T, Fujita T, Komuro I. Mechanical stress activates angiotensin II type 1 receptor without the involvement of angiotensin II. Nat Cell Biol 2004; 6: 499-506.

273 Yusuf S, Teo KK, Pogue J, Dyal L, Copland I, Schumacher H, Dagenais G, Sleight P, Anderson C, ONTARGET Investigators. Telmisartan, ramipril, or both in patients at high risk for vascular events. N Engl J Med 2008; 358: 1547-1559. RT

274 Lindholm LH, Ibsen H, Dahlöf B, Devereux RB, Beevers G, de Faire U, Fyhrquist F, Julius S, Kjeldsen SE, Kristiansson K, Lederballe-Pedersen O, Nieminen MS, Omvik P, Oparil S, Wedel H, Aurup P, Edelman J, Snapinn S, LIFE Study Group. Cardiovascular morbidity and mortality in patients with diabetes in the Losartan Intervention For
Endpoint reduction in hypertension study (LIFE): a randomised trial against atenolol. Lancet 2002; 359: 1004-1010. RT

275 Arai T, Sekizawa K, Ohrui T, Fujiwara H, Yoshimi N, Matsuoka H, Sasaki H. ACE inhibitors and protection against pneumonia in elderly patients with stroke. Neurology 2005; 64: 573-574. OS

276 National Intervention Cooperative Study in Elderly Hypertensives Study Group. Randomized double-blind comparison of a calcium antagonist and a diuretic in elderly hypertensives. Hypertension 1999; 34: 1129-1133. RT

277 Messerli FH, Grossman E, Goldbourt U. Are beta-blockers efficacious as first-line therapy for hypertension in the elderly? A systematic review. JAMA 1998; 279: 1903-1907. MA

278 Gress TW, Nieto FJ, Shahar E, Wofford MR, Brancati FL. Hypertension and antihypertensive therapy as risk factors for type 2 diabetes mellitus. Atherosclerosis Risk in Communities Study. N Engl J Med 2000; 342: 905-912. OS

279 Bakris GL, Fonseca V, Katholi RE, McGill JB, Messerli FH, Phillips RA, Raskin P, Wright Jr JT, Oakes R, Lukas MA, Anderson KM, Bell DS, GEMINI Investigators. Metabolic effects of carvedilol vs metoprolol in patients with type 2 diabetes mellitus and hypertension: a randomized controlled trial. JAMA 2004; 292: 2227-2236. RT

280 Karachalios GN, Charalabopoulos A, Papalimneou V, Kiortsis D, Dimicco P, Kostoula $\mathrm{OK}$, Charalabopoulos K. Withdrawal syndrome following cessation of antihypertensive drug therapy. Int J Clin Pract 2005; 59: 562-570. RV

281 Flack JM, Oparil S, Pratt JH, Roniker B, Garthwaite S, Kleiman JH, Yang Y, Krause SL, Workman D, Saunders E. Efficacy and tolerability of eplerenone and losartan in hypertensive black and white patients. J Am Coll Cardiol 2003; 41: 1148-1155. RT

282 Pitt B, Zannad F, Remme WJ, Cody R, Castaigne A, Perez A, Palensky J, Wittes J, Randomized Aldactone Evaluation Study Investigators. The effect of spironolactone on morbidity and mortality in patients with severe heart failure. N Eng/ J Med 1999; 341: 709-717. RT

283 Pitt B, Remme W, Zannad F, Neaton J, Martinez F, Roniker B, Bittman R, Hurley S, Kleiman J, Gatlin M, Eplerenone Post-Acute Myocardial Infarction Heart Failure Efficacy and Survival Study Investigators. Eplerenone, a selective aldosterone blocker, in patients with left ventricular dysfunction after myocardial infarction. $N$ Eng/ J Med 2003; 348: 1309-1321. RT

284 Chapman N, Dobson J, Wilson S, Dahlöf B, Sever PS, Wedel H, Poulter NR, Anglo-Scandinavian Cardiac Outcomes Trial Investigators. Effect of spironolactone on blood pressure in subjects with resistant hypertension. Hypertension 2007; 49: 839-845. RT

285 Hasebe N, Kikuchi K, NICE Combi Study Group. Controlled-release nifedipine and candesartan low-dose combination therapy in patients with essential hypertension: the NICE Combi (Nifedipine and Candesartan Combination) Study. J Hypertens 2005; 23: 445-453. RT

286 Saito I, Saruta T, ADVANCE-Combi Study Group. Controlled release nifedipine and valsartan combination therapy in patients with essential hypertension: the adalat $C R$ and valsartan cost-effectiveness combination (ADVANCE-combi) study. Hypertens Res 2006; 29: 789-796. RT

287 Pepine CJ, Handberg EM, Cooper-DeHoff RM, Marks RG, Kowey P, Messerli FH, Mancia G, Cangiano JL, Garcia-Barreto D, Keltai M, Erdine S, Bristol HA, Kolb HR, Bakris GL, Cohen JD, Parmley WW, INVEST Investigators. A calcium antagonist vs a non-calcium antagonist hypertension treatment strategy for patients with coronary artery disease. The International Verapamil-Trandolapril Study (INVEST): a randomized controlled trial. JAMA 2003; 290: 2805-2816. RT

288 Poole-Wilson PA, Lubsen J, Kirwan BA, van Dalen FJ, Wagener G, Danchin N, Just H, Fox KA, Pocock SJ, Clayton TC, Motro M, Parker JD, Bourassa MG, Dart AM, Hildebrandt P, Hjalmarson A, Kragten JA, Molhoek GP, Otterstad JE, Seabra-Gomes R, Soler-Soler J, Weber S, A Coronary disease Trial Investigating Outcome with Nifedipine gastrointestinal therapeutic system investigators. Effect of long-acting nifedipine on mortality and cardiovascular morbidity in patients with stable angina requiring treatment (ACTION trial): randomised controlled trial. Lancet 364: 849-857. RT

289 Ohta Y, Tsuchihashi T, Onaka U, Eto K, Ueno M. Usefulness of the alpha1-blocker doxazosin as a third-line antihypertensive drug. Hypertens Res 2007; 30: 301-306. CT

290 Patel A, MacMahon S, Chalmers J, Neal B, Woodward M, Billot L, Harrap S, Poulter N, Marre M, Cooper M, Glasziou P, Grobbee DE, Hamet P, Heller S, Liu LS, Mancia G, Mogensen CE, Pan CY, Rodgers A, Williams B, ADVANCE Collaborative Group. Effects of a fixed combination of perindopril and indapamide on macrovascular and microvascular outcomes in patients with type 2 diabetes mellitus (the ADVANCE trial): a randomised controlled trial. Lancet 2007; 370: 829-840. RT

291 Jamerson KA, Bakris GL, Wun CC, Dahlöf B, Lefkowitz M, Manfreda S, Pitt B, Velazquez EJ, Weber MA. Rationale and design of the avoiding cardiovascular events through combination therapy in patients living with systolic hypertension (ACCOMPLISH) trial: the first randomized controlled trial to compare the clinical outcome effects of first-line combination therapies in hypertension. Am J Hypertens 2004; 17: 793-801. RT

292 Moser M, Setaro JF. Clinical practice. Resistant or difficult-to-control hypertension. N Engl J Med 2006; 355: 385-392. RV

293 Cuspidi C, Macca G, Sampieri L, Michev I, Salerno M, Fusi V, Severgnini B, Meani S, Magrini $F$, Zanchetti A. High prevalence of cardiac and extracardiac target organ damage in refractory hypertension. J Hypertens 2001; 19: 2063-2070. OS

294 Kaplan NM. Treatment of hypertension. In: Kaplan's Clinical Hypertension, 9th edn. Lippincott Williams \& Wilkins: Philadelphia, 2006, pp 217-310. 
295 ALLHAT Officers and Coordinators for the ALLHAT Collaborative Research Group. The Antihypertensive and Lipid-Lowering Treatment to Prevent Heart Attack Trial. Major outcomes in high-risk hypertensive patients randomized to angiotensin-converting enzyme inhibitor or calcium channel blocker vs diuretic: The Antihypertensive and Lipid-Lowering Treatment to Prevent Heart Attack Trial (ALLHAT). JAMA 2002; 288: 2981-2997. RT

296 Black HR, Elliott WJ, Grandits G, Grambsch P, Lucente T, White WB, Neaton JD, Grimm Jr RH, Hansson L, Lacourciere Y, Muller J, Sleight P, Weber MA, Williams G, Wittes J, Zanchetti A, Anders RJ, CONVINCE Research Group. Principal results of the Controlled Onset Verapamil Investigation of Cardiovascular End Points (CONVINCE) trial. JAMA 289: 2073-2082. RT

297 Brown MJ, Palmer CR, Castaigne A, de Leeuw PW, Mancia G, Rosenthal T, Ruilope LM. Morbidity and mortality in patients randomised to double-blind treatment with a long-acting calcium-channel blocker or diuretic in the International Nifedipine GITS study: Intervention as a Goal in Hypertension Treatment (INSIGHT). Lancet 2000; 356: 366-372. RT

298 Ogihara T, Nakao K, Fukui T, Fukiyama K, Fujimoto A, Ueshima K, Oba K, Shimamoto K, Matsuoka H, Saruta T, CASE-J Trial Group. Candesartan Antihypertensive Survival Evaluation in Japan Trial Group. The optimal target blood pressure for antihypertensive treatment in the Japanese elderly patients with high-risk hypertension: a subanalysis of CASE-J trial. Hypertens Res 2008; 31: 1595-1601. RT

299 Obara T, Ohkubo T, Funahashi J, Kikuya M, Asayama K, Metoki H, Oikawa T, Hashimoto J, Totsune K, Imai Y. Isolated uncontrolled hypertension at home and in the office among treated hypertensive patients from the J-HOME study. J Hypertens 2005; 23: 1653-1660. OS

300 Mori H, Ukai H, Yamamoto H, Saitou S, Hirao K, Yamauchi M, Umemura S. Current status of antihypertensive prescription and associated blood pressure control in Japan. Hypertens Res 2006; 29: 143-151. CT

301 Ohta Y, Tsuchihashi T, Fujii K, Matsumura K, Ohya Y, Uezono K, Abe I, lida M. Improvement of blood pressure control in a hypertension clinic: a 10-year follow-up study. J Hum Hypertens 2004; 18: 273-278. OS

302 Ono A, Fujita T. Factors relating to inadequate control of blood pressure in hypertensive outpatients. Hypertens Res 2003; 26: 219-224. OS

303 Nishizaka MK, Zaman MA, Calhoun DA. Efficacy of low-dose spironolactone in subjects with resistant hypertension. Am J Hypertens 2003; 16: 925-930. CT

304 Calhoun DA, Jones D, Textor S, Goff DC, Murphy TP, Toto RD, White A, Cushman WC, White W, Sica D, Ferdinand K, Giles TD, Falkner B, Carey RM. Resistant hypertension: diagnosis, evaluation, and treatment: a scientific statement from the American heart association professional education committee of the council for high blood pressure research. Hypertension 2008; 51: 1403-1419. GL

305 Broderick JP, Adams HP, Barsan W, Feinberg W, Feldmann E, Grotta J, Kase C, Krieger D, Mayberg M, Tilley B, Zabramski JM, Zuccarello M. Guidelines for the management of spontaneous intracerebral hemorrhage: a statement for healthcare professionals from a special writing group of the Stroke Council, American Heart Association. Stroke 1999; 30: 905-915. GL

306 Adams Jr HP, Brott TG, Crowell RM, Furlan AJ, Gomez CR, Grotta J, Helgason CM, Marler JR, Woolson RF, Zivin JA. Guidelines for the management of patients with acute ischemic stroke. A statement for healthcare professionals from a special writing group of the Stroke Council, American Heart Association. Stroke 1994; 25: 1901-1914. GL

307 Bath P, Chalmers J, Powers W, Beilin L, Davis S, Lenfant C, Mancia G, Neal B, Whitworth J, Zanchetti A, International Society of Hypertension Writing Group. International Society of Hypertension (ISH): statement on the management of blood pressure in acute stroke. J Hypertens 2003; 21: 665-672. GL

308 Osaki Y, Matsubayashi K, Yamasaki M, Okumiya K, Yoshimura K, Yoshimura K, Hamashige N, Doi Y. Post-stroke hypertension correlates with neurologic recovery in patients with acute ischemic stroke. Hypertens Res 1998; 21: 169-173. CT

309 Blood Pressure in Acute Stroke Collaboration (BASC). Interventions for deliberating altering blood pressure in acute stroke. The Cochrane Library, Issue 3, 2003. Update Software, Oxford, 2003.

310 The National Institute of Neurological Disorders and Stroke: Proceedings of national symposium on rapid identification and treatment of acute stroke. NIH publication 1997; No 97-4239: 1-183.

311 Adams HP, del Zoppo G, Alberts MJ, Bhatt DL, Brass L, Furlan A, Grubb RL, Higashida RT, Jauch EC, Kidwell C, Lyden PD, Morgenstern LB, Qureshi Al, Rosenwasser RH, Scott PA, Wijdicks EF, American Heart Association. Guidelines for the early management of adults with ischemic stroke: a guideline from the American Heart Association/ American Stroke Association Stroke Council, Clinical Cardiology Council, Cardiovascular Radiology and Intervention Council, and the Atherosclerotic Peripheral Vascular Disease and Quality of Care Outcomes in Research Interdisciplinary Working Groups: the American Academy of Neurology affirms the value of this guideline as an educational tool for neurologists. Stroke 2007; 38: 1655-1711. GL

312 Schrader J, Lüders S, Kulschewski A, Berger J, Zidek W, Treib J, Einhäupl K, Diener HC, Dominiak P, Acute Candesartan Cilexetil Therapy in Stroke Survivors Study Group. The ACCESS Study: evaluation of Acute Candesartan Cilexetil Therapy in Stroke Survivors. Stroke 2003; 34: 1699-1703. RT

313 Broderick J, Connolly S, Feldmann E, Hanley D, Kase C, Krieger D, Mayberg M, Morgenstern L, Ogilvy CS, Vespa P, Zuccarello M, American Heart Association. Guidelines for the management of spontaneous intracerebral hemorrhage in adults: 2007 update: a guideline from the American Heart Association/American Stroke Association Stroke Council, High Blood Pressure Research Council, and the Quality of Care and Outcomes in Research Interdisciplinary Working Group. Stroke 2007; 38: 2001-2023. GL
314 Anderson CS, Huang Y, Wang JG, Arima H, Neal B, Peng B, Heeley E, Skulina C, Parsons MW, Kim JS, Tao QL, Li YC, Jiang JD, Tai LW, Zhang JL, Xu E, Cheng Y, Heritier S, Morgenstern LB, Chalmers J, INTERACT Investigators. Intensive blood pressure reduction in acute cerebral haemorrhage trial (INTERACT): a randomised pilot trial. Lancet Neurol 2008; 7: 391-399. RT

315 Irie K, Yamaguchi T, Minematsu K, Omae T. The J-curve phenomenon in stroke recurrence. Stroke 1993; 24: 1844-1849.

316 The Dutch TIA Trial Study Group. Trial of secondary prevention with atenolol after transient ischemic attack or nondisabling ischemic stroke. Stroke 1993; 24: 543-548. RT

317 PATS Collaborating Group. Post-stroke antihypertensive treatment study. A preliminary result. Chin Med J (Engl) 1995; 108: 710-717. RT

318 Eriksson S, Olofsson B-V, Wester P-O. Atenolol in secondary prevention after stroke. Cerebrovasc Dis 1995; 5: 21-25.

319 Yusuf S, Sleight P, Pogue J, Bosch J, Davies R, Dagenais G, The Heart Outcomes Prevention Evaluation Study Investigators. Effects of an angiotensin-convertingenzyme inhibitor, ramipril, on cardiovascular events in high-risk patients. $N$ Engl J Med 2000; 342: 145-153. RT

320 Schrader J, Lüders S, Kulschewski A, Hammersen F, Plate K, Berger J, Zidek W, Dominiak P, Diener HC, MOSES Study Group. Morbidity and Mortality After Stroke, Eprosartan Compared with Nitrendipine for Secondary Prevention: principal results of a prospective randomized controlled study (MOSES). Stroke 2005; 36: 1218-1226. RT

321 Rashid P, Leonardi-Bee J, Bath P. Blood pressure reduction and secondary prevention of stroke and other vascular events: a systematic review. Stroke 2003; 34: 27412748. MA

322 Yusuf S, Diener HC, Sacco RL, Cotton D, Ounpuu S, Lawton WA, Palesch Y, Martin $\mathrm{RH}$, Albers GW, Bath P, Bornstein N, Chan BP, Chen ST, Cunha L, Dahlöf B, De Keyser J, Donnan GA, Estol C, Gorelick P, Gu V, Hermansson K, Hilbrich L, Kaste M, Lu C, Machnig T, Pais P, Roberts R, Skvortsova V, Teal P, Toni D, VanderMaelen C, Voigt T, Weber M, Yoon BW, PRoFESS Study Group. Telmisartan to prevent recurrent stroke and cardiovascular events. N Engl J Med 2008; 359: 1225-1237. RT

323 Sacco RL, Adams R, Albers G, Alberts MJ, Benavente O, Furie K, Goldstein LB, Gorelick P, Halperin J, Harbaugh R, Johnston SC, Katzan I, Kelly-Hayes M, Kenton EJ, Marks M, Schwamm LH, Tomsick T, American Heart Association. Guidelines for prevention of stroke in patients with ischemic stroke or transient ischemic attack: a statement for healthcare professionals from the American Heart Association/American Stroke Association Council on Stroke: co-sponsored by the Council on Cardiovascular Radiology and Intervention: the American Academy of Neurology affirms the value of this guideline. Stroke 2006; 37: 577-617. GL

324 Rothwell PM, Howard SC, Spence JD, Carotid Endarterectomy Trialists' Collaboration. Relationship between blood pressure and stroke risk in patients with symptomatic carotid occlusive disease. Stroke 2003; 34: 2583-2590. MA

325 Turan TN, Cotsonis G, Lynn MJ, Chaturvedi S, Chimowitz M, Warfarin-Aspirin Symptomatic Intracranial Disease (WASID) Trial Investigators. Relationship between blood pressure and stroke recurrence in patients with intracranial arterial stenosis. Circulation 2007; 115: 2969-2975. RT

326 Arakawa S, Saku Y, Ibayashi S, Nagao T, Fujishima M. Blood pressure control and recurrence of hypertensive brain hemorrhage. Stroke 1998; 29: 1806-1809. OS

327 Japanese Society for Detection of Asymptomatic Brain Diseases. Guidelines for Detection of Asymptomatic Brain Diseases 2003. (internet) http://www.snh.or.jp/ jsbd/pdf/guideline2003.pdf. GL

328 The Joint Committee on Guidelines for the Management of Stroke. Japanese Guidelines for the Management of Stroke (in Japanese). Kyowa Kikaku: Tokyo, 2004. GL

329 Vermeer SE, Prins ND, den Heijer T, Hofman A, Koudstaal PJ, Breteler MM. Silent brain infarcts and the risk of dementia and cognitive decline. N Engl J Med 2003; 348: $1215-1222$. OS

330 Kinoshita T, Okudera T, Tamura H, Ogawa T, Hatazawa J. Assessment of lacunar hemorrhage associated with hypertensive stroke by echo-planar gradient-echo T2*-weighted MRI. Stroke 2000; 31: 1646-1650. CT

331 Kato H, Izumiyama M, Izumiyama K, Takahashi A, Itoyama Y. Silent cerebral microbleeds on T2*-weighted MRI: correlation with stroke subtype, stroke recurrence, and leukoaraiosis. Stroke 2002; 33: 1536-1540. CT

332 Leary MC, Saver JL. Annual incidence of first silent stroke in the United States: a preliminary estimate. Cerebrovasc Dis 2003; 16: 280-285.

333 Hasegawa Y, Yamaguchi T, Omae T, Woodward M, Chalmers J, PROGRESS CT Substudy Investigators. Effects of perindopril-based blood pressure lowering and of patient characteristics on the progression of silent brain infarct: the Perindopril Protection against Recurrent Stroke Study (PROGRESS) CT Substudy in Japan. Hypertens Res 2004; 27: 147-156. RT

334 Yamamoto Y, Akiguchi I, Oiwa K, Hayashi M, Kimura J. Adverse effect of nighttime blood pressure on the outcome of lacunar infarct patients. Stroke 1998; 29: 570-576. OS

335 Kario K, Pickering TG, Matsuo T, Hoshide S, Schwartz JE, Shimada K. Stroke prognosis and abnormal nocturnal blood pressure falls in older hypertensives. Hypertension 2001; 38: 852-857. OS

336 Staessen JA, Wang JG, Thijs L. Cardiovascular protection and blood pressure reduction: a meta-analysis. Lancet 2001; 358: 1305-1315. MA

337 Moser M, Hebert P, Hennekens $\mathrm{CH}$. An overview of the meta-analyses of the hypertension treatment trials. Arch Intern Med 1991; 151: 1277-1279. MA

338 Pitt B, Byington RP, Furberg CD, Hunninghake DB, Mancini GB, Miller ME, Riley W, PREVENT Investigators. Effect of amlodipine on the progression of atherosclerosis and the occurrence of clinical events. Circulation 2000; 102: 1503-1510. RT 
339 Kondo J, Sone T, Tsuboi H, Mukawa H, Morishima I, Uesugi M, Kono T, Kosaka T, Yoshida T, Numaguchi Y, Matsui H, Murohara T, Okumura K. Effects of low-dose angiotensin II receptor blocker candesartan on cardiovascular events in patients with coronary artery disease. Am Heart J 2003; 146: E20. RT

340 Yui Y, Sumiyoshi T, Kodama K, Hirayama A, Nonogi H, Kanmatsuse K, Origasa H, limura O, Ishii M, Saruta T, Arakawa K, Hosoda S, Kawai C, Japan Multicenter Investigation for Cardiovascular Diseases-B Study Group. Comparison of nifedipine retard with angiotensin converting enzyme inhibitors in Japanese hypertensive patients with coronary artery disease: the Japan Multicenter Investigation for Cardiovascular Diseases-B (JMIC-B) randomized trial. Hypertens Res 2004; 27: 181-191. RT

341 Sacks FM, Pfeffer MA, Moye LA, Rouleau JL, Rutherford JD, Cole TG, Brown L, Warnica JW, Arnold JM, Wun CC, Davis BR, Braunwald E, Cholesterol and Recurrent Events Trial investigators. The effect of pravastatin on coronary events after myocardial infarction in patients with average cholesterol levels. N Engl J Med 1996; 335: 1001-1009. RT

342 Messerli FH, Mancia G, Conti CR, Hewkin AC, Kupfer S, Champion A, Kolloch R, Benetos A, Pepine CJ. Dogma disputed: can aggressively lowering blood pressure in hypertensive patients with coronary artery disease be dangerous? Ann Intern Med 2006; 144: 884-893. OS

343 Thune JJ, Signorovitch J, Kober L, Velazquez EJ, McMurray JJ, Califf RM, Maggioni AP, Rouleau JL, Howlett J, Zelenkofske S, Pfeffer MA, Solomon SD. Effect of antecedent hypertension and follow-up blood pressure on outcomes after high-risk myocardial infarction. Hypertension 2008; 51: 48-54. OS

344 Bradley HA, Wiysonge CS, Volmink JA, Mayosi BM, Opie LH. How strong is the evidence for use of beta-blockers as first-line therapy for hypertension? Systematic review and meta-analysis. J Hypertens 2006; 24: 2131-2141. MA

345 Bangalore S, Messerli FH, Kostis JB, Pepine CJ. Cardiovascular protection using betablockers: a critical review of the evidence. J Am Coll Cardiol 2007; 50: 563-572. RV

346 Pedersen TR. Six-year follow-up of the Norwegian Multicenter Study on Timolol after Acute Myocardial Infarction. N Engl J Med 1985; 313: 1055-1058. RT

347 Dargie HJ. Effect of carvedilol on outcome after myocardial infarction in patients with left-ventricular dysfunction: the CAPRICORN randomised trial. Lancet 2001; 357 1385-1390. RT

348 The Multicenter Diltiazem Postinfarction Trial Research Group. The effect of diltiazem on mortality and reinfarction after myocardial infarction. N Engl J Med 1988; 319 385-392. RT

349 Japanese beta-Blockers and Calcium Antagonists Myocardial Infarction (JBCMI) Investigators. Comparison of the effects of beta blockers and calcium antagonists on cardiovascular events after acute myocardial infarction in Japanese subjects. $A m \mathrm{~J}$ Cardiol 2004; 93: 969-973. RT

350 Yui Y, Shinoda E, Kodama K, Hirayama A, Nonogi H, Haze K, Sumiyoshi T, Hosoda S, Kawai C, Japan Multicenter Investigation for Cardiovascular Diseases B (JMIC-B) Study Group. Nifedipine retard prevents hospitalization for angina pectoris better than angiotensin-converting enzyme inhibitors in hypertensive Japanese patients with previous myocardial infarction (JMIC-B substudy). J Hypertens 2007; 25 2019-2026. RT

351 Ishikawa K, Nakai S, Takenaka T, Kanamasa K, Hama J, Ogawa I, Yamamoto T, Oyaizu M, Kimura A, Yamamoto K, Yabushita H, Katori R. Short-acting nifedipine and diltiazem do not reduce the incidence of cardiac events in patients with healed myocardial infarction. Secondary Prevention Group. Circulation 1997; 95: 2368-2373. CT

352 Pfeffer MA, Braunwald E, Moyé LA, Basta L, Brown EJ, Cuddy TE, Davis BR, Geltman EM, Goldman S, Flaker GC. The SAVE Investigators. Effect of captopril on mortality and morbidity in patients with left ventricular dysfunction after myocardial infarction. Results of the survival and ventricular enlargement trial. N Engl J Med 1992; 327 669-677. RT

353 Pfeffer MA, McMurray JJ, Velazquez EJ, Rouleau J-L, Køber L, Maggioni AP, Solomon SD, Swedberg K, Van de Werf F, White $H$, Leimberger JD, Henis M, Edwards S, Zelenkofske S, Sellers MA, Califf RM, for the Valsartan in Acute Myocardial Infarction Trial Investigators. Valsartan, captopril, or both in myocardial infarction complicated by heart failure, left ventricular dysfunction, or both. N Engl J Med 2003; 349: 18931906. RT

354 Tsutsui H, Tsuchihashi-Makaya M, Kinugawa S, Goto D, Takeshita A, JCARE-GENERAL Investigators. Characteristics and outcomes of patients with heart failure in general practices and hospitals. Circ J 2007; 71: 449-454. OS

355 Veterans Administration Cooperative Study Group on Antihypertensive Agents. Effects of treatment on morbidity in hypertension. II. Results in patients with diastolic blood pressure averaging 90 through $114 \mathrm{~mm} \mathrm{Hg}$. JAMA 1970; 213 1143-1152. RT

356 The SOLVD Investigators. Effect of enalapril on survival in patients with reduced left ventricular ejection fractions and congestive heart failure. N Engl J Med 1991; 325: 293-302. RT

357 The SOLVD Investigattors. Effect of enalapril on mortality and the development of heart failure in asymptomatic patients with reduced left ventricular ejection fractions. N Engl J Med 1992; 327: 685-691. RT

358 Cohn JN, Tognoni G, Valsartan Heart Failure Trial Investigators. A randomized trial of the angiotensin-receptor blocker valsartan in chronic heart failure. $N$ Engl J Med 2001; 345: 1667-1675. RT

359 Pfeffer MA, Swedberg K, Granger CB, Held P, McMurray JJ, Michelson EL, Olofsson B, Ostergren J, Yusuf S, Pocock S, CHARM Investigators and Committees. Effects of candesartan on mortality and morbidity in patients with chronic heart failure: the CHARM-Overall programme. Lancet 2003; 362: 759-766. RT
360 Granger CB, McMurray JJ, Yusuf S, Held P, Michelson EL, Olofsson B, Ostergren J, Pfeffer MA, Swedberg K, CHARM Investigators and Committees. Effects of candesartan in patients with chronic heart failure and reduced left-ventricular systolic function intolerant to angiotensin-converting-enzyme inhibitors: the CHARM-Alternative trial. Lancet 2003; 362: 772-776. RT

361 Yusuf S, Pfeffer MA, Swedberg K, Held P, McMurray JJ, Michelson EL, Olofsson B, Ostergren J, CHARM Investigators and Committees. Effects of candesartan in patients with chronic heart failure and preserved left-ventricular ejection fraction: the CHARMPreserved Trial. Lancet 2003; 362: 777-781. RT

362 Packer M, Bristow MR, Cohn JN, Colucci WS, Fowler MB, Gilbert EM, Shusterman $\mathrm{NH}$, US Carvedilol Heart Failure Study Group. The effect of carvedilol on morbidity and mortality in patients with chronic heart failure. N Engl J Med 1996; 334: 1349-1355. RT

363 Hjalmarson A, Goldstein S, Fagerberg B, Wedel H, Waagstein F, Kjekshus J, Wikstrand $\mathrm{J}$, El Allaf D, Vítovec J, Aldershvile J, Halinen M, Dietz R, Neuhaus KL, Jánosi A, Thorgeirsson G, Dunselman PH, Gullestad L, Kuch J, Herlitz J, Rickenbacher P, Ball S, Gottlieb S, Deedwania P, MERIT-HF Study Group. Effects of controlled-release metoprolol on total mortality, hospitalizations, and well-being in patients with heart failure: the Metoprolol CR/XL Randomized Intervention Trial in congestive heart failure (MERIT-HF). JAMA 2000; 283: 1295-1302. RT

364 CIBIS-II Investigators and Committees. The Cardiac Insufficiency Bisoprolol Study II (CIBIS-II): a randomised trial. Lancet 1999; 353: 9-13. RT

365 Packer M, Coats AJ, Fowler MB, Katus HA, Krum H, Mohacsi P, Rouleau JL, Tendera M, Castaigne A, Roecker EB, Schultz MK, DeMets DL, Carvedilol Prospective Randomized Cumulative Survival Study Group. Effect of carvedilol on survival in severe chronic heart failure. N Engl J Med 2001; 344: 1651-1658. RT

366 Hunt SA, Baker DW, Chin MH, Cinquegrani MP, Feldman AM, Francis GS, Ganiats TG, Goldstein S, Gregoratos G, Jessup ML, Noble RJ, Packer M, Silver MA, Stevenson LW, Gibbons RJ, Antman EM, Alpert JS, Faxon DP, Fuster V, Gregoratos G, Jacobs AK, Hiratzka LF, Russell RO, Smith Jr SC. American College of Cardiology/American Heart Association Task Force on Practice Guidelines (Committee to Revise the 1995 Guidelines for the Evaluation and Management of Heart Failure). ACC/AHA Guidelines for the Evaluation and Management of Chronic Heart Failure in the Adult: Executive Summary A Report of the American College of Cardiology/American Heart Association Task Force on Practice Guidelines (Committee to Revise the 1995 Guidelines for the Evaluation and Management of Heart Failure): Developed in Collaboration With the International Society for Heart and Lung Transplantation; Endorsed by the Heart Failure Society of America. Circulation 2001; 104: 2996-3007. GL

367 Packer M, O'Connor CM, Ghali JK, Pressler ML, Carson PE, Belkin RN, Miller AB, Neuberg GW, Frid D, Wertheimer JH, Cropp AB, DeMets DL. Prospective Randomized Amlodipine Survival Evaluation Study Group. Effect of amlodipine on morbidity and mortality in severe chronic heart failure. N Engl J Med 1996; 335: 1107-1114. RT

368 Levy D, Garrison RJ, Savage DD, Kannel WB, Castelli WP. Prognostic implications of echocardiographically determined left ventricular mass in the Framingham Heart Study. N Eng/ J Med 1990; 322: 1561-1566. OS

369 Verdecchia P, Schillaci G, Borgioni C, Ciucci A, Gattobigio R, Zampi I, Reboldi G, Porcellati $C$. Prognostic significance of serial changes in left ventricular mass in essential hypertension. Circulation 97: 48-54. OS

370 Wachtell K, Okin PM, Olsen MH, Dahlöf B, Devereux RB, Ibsen H, Kjeldsen SE, Lindholm LH, Nieminen MS, Thygesen K. Regression of electrocardiographic left ventricular hypertrophy during antihypertensive therapy and reduction in sudden cardiac death: the LIFE Study. Circulation 2007; 116: 700-705. RT

371 Klingbeil AU, Schneider M, Martus P, Messerli FH, Schmieder RE. A meta-analysis of the effects of treatment on left ventricular mass in essential hypertension. Am J Med 2003; 115: 41-46. MA

372 Sato A, Hayashi M, Saruta T. Relative long-term effects of spironolactone in conjunction with an angiotensin-converting enzyme inhibitor on left ventricular mass and diastolic function in patients with essential hypertension. Hypertens Res 2002; 25: 837-842. RT

373 Taniguchi I, Kawai M, Date T, Yoshida S, Seki S, Taniguchi M, Shimizu M, Mochizuki $\mathrm{S}$. Effects of spironolactone during an angiotensin II receptor blocker treatment on the left ventricular mass reduction in hypertensive patients with concentric left ventricular hypertrophy. Circ J 2006; 70: 995-1000. RT

374 Gottdiener JS, Reda DJ, Massie BM, Materson BJ, Williams DW, Anderson RJ, The Department of Veterans Affairs Cooperative Study Group on Antihypertensive Agents. Effect of single-drug therapy on reduction of left ventricular mass in mild to moderate hypertension: comparison of six antihypertensive agents. Circulation 1997; 95: 2007-2014. RT

375 Krahn AD, Manfreda J, Tate RB, Mathewson FA, Cuddy TE. The natural history of atrial fibrillation: incidence, risk factors, and prognosis in the Manitoba Follow-Up Study. Am J Med 1995; 98: 476-484. OS

376 Stewart S, Hart CL, Hole DJ, McMurray JJ. A population-based study of the long-term risks associated with atrial fibrillation: 20-year follow-up of the Renfrew/Paisley study. Am J Med 2002; 113: 359-364. OS

377 Kannel WB, Wolf PA, Benjamin EJ, Levy D. Prevalence, incidence, prognosis, and predisposing conditions for atrial fibrillation: population-based estimates. Am J Cardiol 1998; 82: 2N-9N. OS

378 Okin PM, Wachtell K, Devereux RB, Harris KE, Jern S, Kjeldsen SE, Julius S, Lindholm LH, Nieminen MS, Edelman JM, Hille DA, Dahlöf B. Regression of electrocardiographic left ventricular hypertrophy and decreased incidence of new-onset atrial fibrillation in patients with hypertension. JAMA 2006; 296 : 1242-1248. OS 
379 Rienstra M, Van Veldhuisen DJ, Crijns HJ, Van Gelder IC. RACE Investigators. Enhanced cardiovascular morbidity and mortality during rhythm control treatment in persistent atrial fibrillation in hypertensives: data of the RACE study. Eur Heart $J$ 2007; 28: 741-751. RT

380 Lip GY, Frison L, Grind M, SPORTIF Investigators. Effect of hypertension on anticoagulated patients with atrial fibrillation. Eur Heart J 2007; 28: 752-759. OS

381 Wachtell K, Lehto M, Gerdts E, Olsen MH, Hornestam B, Dahlöf B, Ibsen H, Julius S, Kjeldsen SE, Lindholm LH, Nieminen MS, Devereux RB. Angiotensin II receptor blockade reduces new-onset atrial fibrillation and subsequent stroke compared to atenolol: the Losartan Intervention For End Point Reduction in Hypertension (LIFE) study. J Am Coll Cardiol 2005; 45: 712-719. RT

382 Anand K, Mooss AN, Hee TT, Mohiuddin SM. Meta-analysis: inhibition of reninangiotensin system prevents new-onset atrial fibrillation. Am Heart $J$ 2006; 152 : 217-222. MA

383 Healey JS, Baranchuk A, Crystal E, Morillo CA, Garfinkle M, Yusuf S, Connolly SJ. Prevention of atrial fibrillation with angiotensin-converting enzyme inhibitors and angiotensin receptor blockers: a meta-analysis. J Am Coll Cardiol 2005; 45: 1832-1839. MA

384 Hirayama Y, Atarashi H, Kobayashi Y, Horie T, Iwasaki Y, Maruyama M, Miyauchi Y, Ohara T, Yashima M, Takano T. Angiotensin-converting enzyme inhibitor therapy inhibits the progression from paroxysmal atrial fibrillation to chronic atrial fibrillation. Circ J 2005; 69: 671-676. OS

385 Hennersdorf MG, Schueller PO, Steiner S, Strauer BE. Prevalence of paroxysmal atrial fibrillation depending on the regression of left ventricular hypertrophy in arterial hypertension. Hypertens Res 2007; 30: 535-540. OS

386 Imai E, Horio M, Yamagata K, Iseki K, Hara S, Ura N, Kiyohara Y, Makino H, Hishida A, Matsuo S. Slower decline of glomerular filtration rate in the Japanese general population: a longitudinal 10 year follow-up study. Hypertens Res 2008; 31 : 433-441.

387 Bakris GL, Williams M, Dworkin L, Elliott WJ, Epstein M, Toto R, Tuttle K, Douglas J, Hsueh W, Sowers J, National Kidney Foundation Hypertension and Diabetes Executive Committees Working Group. Preserving renal function in adults with hypertension and diabetes: a consensus approach. Am J Kidney Dis 2000; 36: 646-661. GL

388 Klag MJ, Whelton PK, Randall BL, Neaton JD, Brancati FL, Ford CE, Shulman NB, Stamler J. Blood pressure and end-stage renal disease in men. N Engl J Med 1996; 334: 13-18. OS

389 Tozawa M, Iseki K, Iseki C, Kinjo K, Ikemiya Y, Takishita S. Blood pressure predicts risk of developing end-stage renal disease in men and women. Hypertension 2003; 41: 1341-1345. OS

390 The GISEN Group (Gruppo Italiano di Studi Epidemiologici in Nefrologia. Randomised placebo-controlled trial of effect of ramipril on decline in glomerular filtration rate and risk of terminal renal failure in proteinuric, non-diabetic nephropathy. Lancet 1997; 349: 1857-1863. RT

391 de Zeeuw D, Remuzzi G, Parving HH, Keane WF, Zhang Z, Shahinfar S, Snapinn S, Cooper ME, Mitch WE, Brenner BM. Proteinuria, a target for renoprotection in patients with type 2 diabetic nephropathy: lessons from RENAAL. Kidney Int 2004; 65: 2309-2320. RT

392 Keane WF, Brenner BM, de Zeeuw D, Grunfeld JP, McGill J, Mitch WE, Ribeiro AB, Shahinfar S, Simpson RL, Snapinn SM, Toto R, RENAAL Study Investigators. The risk of developing end-stage renal disease in patients with type 2 diabetes and nephropathy: the RENAAL study. Kidney Int 2003; 63: 1499-1507. OS

393 Keith DS, Nichols GA, Gullion CM, Brown JB, Smith DH. Longitudinal follow-up and outcomes among a population with chronic kidney disease in a large managed care organization. Arch Intern Med 2004; 164: 659-663. OS

394 Go AS, Chertow GM, Fan D, McCulloch CE, Hsu CY. Chronic kidney disease and the risks of death, cardiovascular events, and hospitalization. N Engl J Med 2004; 351: 1296-1305. OS

395 Levey AS, Coresh J, Balk E, Kausz AT, Levin A, Steffes MW, Hogg RJ, Perrone RD, Lau J, Eknoyan G, National Kidney Foundation. National Kidney Foundation practice guidelines for chronic kidney disease: evaluation, classification, and stratification. Ann Intern Med 2003; 139: 137-147. GL

396 Manjunath G, Tighiouart H, Ibrahim H, MacLeod B, Salem DN, Griffith JL, Coresh J, Levey AS, Sarnak MJ. Level of kidney function as a risk factor for atherosclerotic cardiovascular outcomes in the community. J Am Coll Cardiol 2003; 41: 47-55. OS

397 Hillege HL, Girbes AR, de Kam PJ, Boomsma F, de Zeeuw D, Charlesworth A, Hampton JR, van Veldhuisen DJ. Renal function, neurohormonal activation, and survival in patients with chronic heart failure. Circulation 2000; 102: 203-210. RT

398 Anavekar NS, McMurray JJ, Velazquez EJ, Solomon SD, Kober L, Rouleau JL, White HD, Nordlander R, Maggioni A, Dickstein K, Zelenkofske S, Leimberger JD, Califf RM, Pfeffer MA. Relation between renal dysfunction and cardiovascular outcomes after myocardial infarction. N Engl J Med 2004; 351: 1285-1295. RT

399 Mann JF, Gerstein HC, Pogue J, Bosch J, Yusuf S. Renal insufficiency as a predictor of cardiovascular outcomes and the impact of ramipril: the HOPE randomized trial. Ann Intern Med 2001; 134: 629-636. CT

400 Ruilope LM, Salvetti A, Jamerson K, Hansson L, Warnold I, Wedel H, Zanchetti A. Renal function and intensive lowering of blood pressure in hypertensive participants of the hypertension optimal treatment (HOT) study. J Am Soc Nephrol 2001; 12: 218-225. RT

401 Manjunath G, Tighiouart H, Coresh J, Macleod B, Salem DN, Griffith JL, Levey AS, Sarnak MJ. Level of kidney function as a risk factor for cardiovascular outcomes in the elderly. Kidney Int 2003; 63: 1121-1129. OS
402 Weiner DE, Tabatabai S, Tighiouart H, Elsayed E, Bansal N, Griffith J, Salem DN, Levey AS, Sarnak MJ. Cardiovascular outcomes and all-cause mortality: exploring the interaction between CKD and cardiovascular disease. Am J Kidney Dis 2006; 48: 392-401. MA

403 Ohtake T, Kobayashi S, Moriya H, Negishi K, Okamoto K, Maesato K, Saito S. High prevalence of occult coronary artery stenosis in patients with chronic kidney disease at the initiation of renal replacement therapy: an angiographic examination. J Am Soc Nephrol 2005; 16: 1141-1148. OS

404 Mogensen CE. Microalbuminuria predicts clinical proteinuria and early mortality in maturity-onset diabetes. N Engl J Med 1984; 310: 356-360. OS

405 Adler Al, Stevens RJ, Manley SE, Bilous RW, Cull CA, Holman RR, UKPDS GROUP. Development and progression of nephropathy in type 2 diabetes: the United Kingdom Prospective Diabetes Study (UKPDS 64). Kidney Int 2003; 63: 225-232. RT

406 Gerstein HC, Mann JF, Yi Q, Zinman B, Dinneen SF, Hoogwerf B, Hallé JP, Young J, Rashkow A, Joyce C, Nawaz S, Yusuf S, HOPE Study Investigators. Albuminuria and risk of cardiovascular events, death, and heart failure in diabetic and nondiabetic individuals. JAMA 2001; 286: 421-426. OS

407 Hillege HL, Fidler V, Diercks GF, van Gilst WH, de Zeeuw D, van Veldhuisen DJ, Gans RO, Janssen WM, Grobbee DE, de Jong PE, Prevention of Renal and Vascular End Stage Disease (PREVEND) Study Group. Urinary albumin excretion predicts cardiovascular and noncardiovascular mortality in general population. Circulation 2002; 106: 1777-1782. OS

408 Wada M, Nagasawa H, Kurita K, Koyama S, Arawaka S, Kawanami T, Tajima K, Daimon M, Kato T. Microalbuminuria is a risk factor for cerebral small vessel disease in community-based elderly subjects. J Neurol Sci 2007; 255: 27-34. OS

409 Ibsen H, Olsen MH, Wachtell K, Borch-Johnsen K, Lindholm LH, Mogensen CE, Dahlöf B, Snapinn SM, Wan Y, Lyle PA. Does albuminuria predict cardiovascular outcomes on treatment with losartan versus atenolol in patients with diabetes, hypertension, and left ventricular hypertrophy? The LIFE study. Diabetes Care 2006; 29: 595-600. CT

410 Coresh J, Selvin E, Stevens LA, Manzi J, Kusek JW, Eggers P, Van Lente F, Levey AS. Prevalence of chronic kidney disease in the United States. JAMA 2007; 298: 2038-2047. OS

411 Yokoyama H, Kawai K, Kobayashi M, Japan Diabetes Clinical Data Management Study Group. Microalbuminuria is common in Japanese type 2 diabetic patients: a nationwide survey from the Japan Diabetes Clinical Data Management Study Group (JDDM 10). Diabetes Care 2007; 30: 989-992. OS

412 Schrier RW, Estacio RO, Mehler PS, Hiatt WR. Appropriate blood pressure control in hypertensive and normotensive type 2 diabetes mellitus: a summary of the ABCD trial. Nat Clin Pract Nephrol 2007; 3: 428-438. RV

413 Pohl MA, Blumenthal S, Cordonnier DJ, De Alvaro F, Deferrari G, Eisner G, Esmatjes E, Gilbert RE, Hunsicker LG, de Faria JB, Mangili R, Moore Jr J, Reisin E, Ritz E, Schernthaner G, Spitalewitz S, Tindall H, Rodby RA, Lewis EJ. Independent and additive impact of blood pressure control and angiotensin II receptor blockade on renal outcomes in the irbesartan diabetic nephropathy trial: clinical implications and limitations. J Am Soc Nephrol 2005; 16: 3027-3037. CT

414 Araki S, Haneda M, Koya D, Hidaka H, Sugimoto T, Isono M, Isshiki K, Chin-Kanasaki M, Uzu T, Kashiwagi A. Reduction in microalbuminuria as an integrated indicator for renal and cardiovascular risk reduction in patients with type 2 diabetes. Diabetes 2007; 56: 1727-1730. OS

415 Uzu T, Sawaguchi M, Maegawa H, Kashiwagi A, Shiga Microalbuminuria Reduction Trial (SMART) Group. Reduction of microalbuminuria in patients with type 2 diabetes: the Shiga Microalbuminuria Reduction Trial (SMART). Diabetes Care 2007; 30: 1581-1583. CT

416 Makino H, Haneda M, Babazono T, Moriya T, Ito S, Iwamoto Y, Kawamori R, Takeuchi M, Katayama S, INNOVATION Study Group. Prevention of transition from incipient to overt nephropathy with telmisartan in patients with type 2 diabetes. Diabetes Care 2007; 30: 1577-1578. RT

417 Ogawa S, Takeuchi K, Mori T, Nako K, Tsubono Y, Ito S. Effects of monotherapy of temocapril or candesartan with dose increments or combination therapy with both drugs on the suppression of diabetic nephropathy. Hypertens Res 2007; 30: 325-334. RT

418 Iseki K, Ikemiya Y, Kinjo K, Inoue T, Iseki C, Takishita S. Body mass index and the risk of development of end-stage renal disease in a screened cohort. Kidney Int 2004; 65: 1870-1876. OS

419 Tozawa M, Iseki K, Iseki C, Oshiro S, Ikemiya Y, Takishita S. Influence of smoking and obesity on the development of proteinuria. Kidney Int 2002; 62: 956-962. OS

420 Kambham N, Markowitz GS, Valeri AM, Lin J, D'Agati VD. Obesity-related glomerulopathy: an emerging epidemic. Kidney Int 2001; 59: 1498-1509. OS

421 Orth SR. Smoking and the kidney. J Am Soc Nephrol 2002; 13: 1663-1672.

422 Parving HH, Lewis JB, Ravid M, Remuzzi G, Hunsicker LG, DEMAND investigators. Prevalence and risk factors for microalbuminuria in a referred cohort of type II diabetic patients: a global perspective. Kidney Int 2006; 69: 2057-2063. OS

423 Japanese Society of Nephrology. Guidelines for life style and dietary therapy for kidney diseases. The Japanese Society of Nephrology. Nippon Jinzo Gakkai Shi 1997; 39: 1-37. Japanese. GL

424 Nakao T, Sanaka T, Tsubakihara Y, Hattori M, Honda M, Mizuiri S, Watanabe Y, Kanazawa Y, Kanno T. Dietary recommendations for chronic kidney disease, 2007. Nippon Jinzo Gakkai Shi 2007; 49: 871-878. Japanese. GL

425 Pedrini MT, Levey AS, Lau J, Chalmers TC, Wang PH. The effect of dietary protein restriction on the progression of diabetic and nondiabetic renal diseases: a metaanalysis. Ann Intern Med 1996; 124: 627-632. MA 
426 Jafar TH, Stark PC, Schmid CH, Landa M, Maschio G, de Jong PE, de Zeeuw D, Shahinfar S, Toto R, Levey AS, AIPRD Study Group. Progression of chronic kidney disease: the role of blood pressure control, proteinuria, and angiotensinconverting enzyme inhibition: a patient-level meta-analysis. Ann Intern Med 2003; 139: 244-252. MA

427 Levey AS, Greene T, Beck GJ, Caggiula AW, Kusek JW, Hunsicker LG, Klahr S, Modification of Diet in Renal Disease Study group. Dietary protein restriction and the progression of chronic renal disease: what have all of the results of the MDRD study shown? J Am Soc Nephrol 1999; 10: 2426-2439. CT

428 Casas JP, Chua W, Loukogeorgakis S, Vallance P, Smeeth L, Hingorani AD, MacAllister RJ. Effect of inhibitors of the renin-angiotensin system and other antihypertensive drugs on renal outcomes: systematic review and meta-analysis. Lancet 2005; 366: 2026-2033. MA

429 Wright Jr JT, Bakris G, Greene T, Agodoa LY, Appel LJ, Charleston J, Cheek D, DouglasBaltimore JG, Gassman J, Glassock R, Hebert L, Jamerson K, Lewis J, Phillips RA, Toto RD, Middleton JP, Rostand SG, African American Study of Kidney Disease and Hypertension Study Group. Effect of blood pressure lowering and antihypertensive drug class on progression of hypertensive kidney disease: results from the AASK trial. JAMA 2002; 288: 2421-2431. RT

430 Sarafidis PA, Khosla N, Bakris GL. Antihypertensive therapy in the presence of proteinuria. Am J Kidney Dis 2007; 49: 12-26. RV

431 PROCOPA Study Group. Dissociation between blood pressure reduction and fall in proteinuria in primary renal disease: a randomized double-blind trial. J Hypertens 2002; 20: 729-737. RT

432 Hollenberg NK, Parving HH, Viberti G, Remuzzi G, Ritter S, Zelenkofske S, Kandra A Daley WL, Rocha R. Albuminuria response to very high-dose valsartan in type 2 diabetes mellitus. J Hypertens 2007; 25: 1921-1926. RT

433 MacKinnon M, Shurraw S, Akbari A, Knoll GA, Jaffey J, Clark HD. Combination therapy with an angiotensin receptor blocker and an ACE inhibitor in proteinuric renal disease: a systematic review of the efficacy and safety data. Am J Kidney Dis 2006; 48: 8-20. MA

434 Kunz R, Friedrich C, Wolbers M, Mann JF. Meta-analysis: effect of monotherapy and combination therapy with inhibitors of the renin angiotensin system on proteinuria in renal disease. Ann Intern Med 2008; 148: 30-48. MA

435 Lewis EJ, Hunsicker LG, Clarke WR, Berl T, Pohl MA, Lewis JB, Ritz E, Atkins RC, Rohde R, Raz I, Collaborative Study Group. Renoprotective effect of the angiotensinreceptor antagonist irbesartan in patients with nephropathy due to type 2 diabetes. N Engl J Med 2001; 345: 851-860. RT

436 Solomon SD, Rice MM, A Jablonski K, Jose P, Domanski M, Sabatine M, Gersh BJ, Rouleau J, Pfeffer MA, Braunwald E, Prevention of Events with ACE inhibition (PEACE) Investigators. Renal function and effectiveness of angiotensin-converting enzyme inhibitor therapy in patients with chronic stable coronary disease in the Prevention of Events with ACE inhibition (PEACE) trial. Circulation 2006; 114: 26-31. RT

437 Ruggenenti P, Perna A, Remuzzi G, GISEN Group Investigators. Retarding progression of chronic renal disease: the neglected issue of residual proteinuria. Kidney Int 2003; 63: 2254-2261. RT

438 de Zeeuw D. Albuminuria, just a marker for cardiovascular disease, or is it more? J Am Soc Nephrol 2005; 16: 1883-1885.

439 Keane WF, Eknoyan G. Proteinuria, albuminuria, risk, assessment, detection, elimination (PARADE): a position paper of the National Kidney Foundation. Am J Kidney Dis 1999; 33: 1004-1010. GL

440 Kidney Disease Outcomes Quality Initiative (K/DOQI). K/DOQI clinical practice guidelines on hypertension and antihypertensive agents in chronic kidney disease. $\mathrm{Am} \mathrm{J}$ Kidney Dis 2004; 43: S1-290. GL

441 Sato A, Hayashi K, Naruse M, Saruta T. Effectiveness of aldosterone blockade in patients with diabetic nephropathy. Hypertension 2003; 41: 64-68. CT

442 Bianchi S, Bigazzi R, Campese VM. Long-term effects of spironolactone on proteinuria and kidney function in patients with chronic kidney disease. Kidney Int 2006; 70: 2116-2123. RT

443 Ruggenenti P, Perna A, Loriga G, Ganeva M, Ene-lordache B, Turturro M, Lesti M, Perticucci E, Chakarski IN, Leonardis D, Garini G, Sessa A, Basile C, Alpa M, Scanziani R, Sorba G, Zoccali C, Remuzzi G, REIN-2 Study Group. Blood-pressure control for renoprotection in patients with non-diabetic chronic renal disease (REIN-2): multicentre, randomised controlled trial. Lancet 365: 939-946. RT

444 Baba S, J-MIND Study Group. Nifedipine and enalapril equally reduce the progression of nephropathy in hypertensive type 2 diabetics. Diabetes Res Clin Pract 2001; 54: 191-201. RT

445 Hayashi K, Kumagai $H$, Saruta T. Effect of efonidipine and ACE inhibitors on proteinuria in human hypertension with renal impairment. Am J Hypertens 2003; 16: 116-122. RT

446 Katayama K, Nomura S, Ishikawa H, Murata T, Koyabu S, Nakano T. Comparison between valsartan and valsartan plus cilnidipine in type II diabetics with normo- and microalbuminuria. Kidney Int 2006; 70: 151-156. RT

447 Ogawa S, Mori T, Nako K, Ito S. Combination therapy of renin-angiotensin system inhibitors and calcium channel blocker, azelnidipine decreases plasma inflammatory markers and urinary oxidative stress markers in patients with diabetic nephropathy. Hypertens Res 2008; 31: 1147-1155.

448 Zager PG, Nikolic J, Brown RH, Campbell MA, Hunt WC, Peterson D, Van Stone J, Levey A, Meyer KB, Klag MJ, Johnson HK, Clark E, Sadler JH, Teredesai P, Medical Directors of Dialysis Clinic, Inc.. 'U' curve association of blood pressure and mortality in hemodialysis patients. Kidney Int 1998; 54: 561-569. OS
449 Mazzuchi N, Carbonell E, Fernández-Cean J. Importance of blood pressure control in hemodialysis patient survival. Kidney Int 2000; 58: 2147-2154. OS

450 Iseki K, Miyasato F, Tokuyama K. Low diastolic blood pressure, hypoalbuminemia, and risk of death in a cohort of chronic hemodialysis patients. Kidney Int 1997; 51: 1212-1217. RV

451 Alborzi P, Patel N, Agarwal R. Home blood pressures are of greater prognostic value than hemodialysis unit recordings. Clin J Am Soc Nephrol 2007; 2: 1228-1234. OS

452 Moriya H, Oka M, Maesato K, Mano T, Ikee R, Ohtake T, Kobayashi S. Weekly averaged blood pressure is more important than a single-point blood pressure measurement in the risk stratification of dialysis patients. Clin J Am Soc Nephrol 2008; 3: 416-422. OS

453 Tozawa M, Iseki K, Iseki C, Takishita S. Pulse pressure and risk of total mortality and cardiovascular events in patients on chronic hemodialysis. Kidney Int 2002; 61: 717-726. OS

454 Shoji T, Tsubakihara Y, Fujii M, Imai E. Hemodialysis-associated hypotension as an independent risk factor for two-year mortality in hemodialysis patients. Kidney Int 2004; 66: 1212-1220.

455 Guerin AP, Blacher J, Pannier B, Marchais SJ, Safar ME, London GM. Impact of aortic stiffness attenuation on survival of patients in end-stage renal failure. Circulation 2001; 103: 987-992. CT

456 Kitahara T, Ono K, Tsuchida A, Kawai H, Shinohara M, Ishii Y, Koyanagi H, Noguchi T, Matsumoto T, Sekihara T, Watanabe Y, Kanai H, Ishida H, Nojima Y. Impact of brachial-ankle pulse wave velocity and ankle-brachial blood pressure index on mortality in hemodialysis patients. Am J Kidney Dis 2005; 46: 688-696. OS

457 London GM, Pannier B, Guerin AP, Blacher J, Marchais SJ, Darne B, Metivier F, Adda $\mathrm{H}$, Safar ME. Alterations of left ventricular hypertrophy in and survival of patients receiving hemodialysis: follow-up of an interventional study. J Am Soc Nephrol 2001; 12: 2759-2767. OS

458 Bragg-Gresham JL, Fissell RB, Mason NA, Bailie GR, Gillespie BW, Wizemann V, Cruz JM, Akiba T, Kurokawa K, Ramirez S, Young EW. Diuretic use, residual renal function, and mortality among hemodialysis patients in the Dialysis Outcomes and Practice Pattern Study (DOPPS). Am J Kidney Dis 2007; 49: 426-431. OS

459 Kestenbaum B, Gillen DL, Sherrard DJ, Seliger S, Ball A, Stehman-Breen C. Calcium channel blocker use and mortality among patients with end-stage renal disease. Kidney Int 2002; 61: 2157-2164.

460 Foley RN, Herzog CA, Collins AJ, United States Renal Data System. Blood pressure and long-term mortality in United States hemodialysis patients: USRDS Waves 3 and 4 Study. Kidney Int 2002; 62: 1784-1790. OS

461 Efrati S, Zaidenstein R, Dishy V, Beberashvili I, Sharist M, Averbukh Z, Golik A, Weissgarten J. ACE inhibitors and survival of hemodialysis patients. Am J Kidney Dis 2002; 40: 1023-1029. OS

462 Shibasaki Y, Masaki H, Nishiue T, Nishikawa M, Matsubara H, Iwasaka T. Angiotensin II type 1 receptor antagonist, losartan, causes regression of left ventricular hypertrophy in end-stage renal disease. Nephron 2002; 90: 256-261. RT

463 Suzuki H, Nakamoto H, Okada H, Sugahara S, Kanno Y. A selective angiotensin receptor antagonist, valsartan, produced regression of left ventricular hypertrophy associated with a reduction of arterial stiffness. Adv Perit Dial 2003; 19: 59-66. RT

464 Ichihara A, Hayashi M, Kaneshiro Y, Takemitsu T, Homma K, Kanno Y, Yoshizawa M, Furukawa T, Takenaka T, Saruta T. Low doses of losartan and trandolapril improve arterial stiffness in hemodialysis patients. Am J Kidney Dis 2005; 45: 866-874. RT

465 Suzuki H, Kanno Y, Sugahara S, Okada H, Nakamoto H. Effects of an angiotensin II receptor blocker, valsartan, on residual renal function in patients on CAPD. Am J Kidney Dis 2004; 43: 1056-1064. RT

466 Japanese Circulation Society. Guidelines for Diagnosis and Treatment of Aortic Aneurysm and Aortic Dissection (JCS 2006). Circ J 2006; 70: 1569-1646. Japanese. GL

467 Ashton HA, Buxton MJ, Day NE, Kim LG, Marteau TM, Scott RA, Thompson SG, Walker NM, Multicentre Aneurysm Screening Study Group. The Multicentre Aneurysm Screening Study (MASS) into the effect of abdominal aortic aneurysm screening on mortality in men: a randomised controlled trial. Lancet 2002; 360: 1531-1539. RT

468 Brewster DC, Cronenwett JL, Hallett JW, Johnston KW, Krupski WC, Matsumura JS, Joint Council of the American Association for Vascular Surgery and Society for Vascular Surgery. Guidelines for the treatment of abdominal aortic aneurysms. Report of a subcommittee of the Joint Council of the American Association for Vascular Surgery and Society for Vascular Surgery. J Vasc Surg 2003; 37: 1106-1117. GL

469 Shores J, Berger KR, Murphy EA, Pyeritz RE. Progression of aortic dilatation and the benefit of long-term beta-adrenergic blockade in Marfan's syndrome. N Engl J Med 1994; 330: 1335-1341. RT

470 Brooke BS, Habashi JP, Judge DP, Patel N, Loeys B, Dietz III HC. Angiotensin II blockade and aortic-root dilation in Marfan's syndrome. N Engl J Med 2008; 358: 2787-2795. OS

471 Lacro RV, Dietz HC, Wruck LM, Bradley TJ, Colan SD, Devereux RB, Klein GL, Li JS, Minich LL, Paridon SM, Pearson GD, Printz BF, Pyeritz RE, Radojewski E, Roman MJ, Saul JP, Stylianou MP, Mahony L, Pediatric Heart Network Investigators. Rationale and design of a randomized clinical trial of beta-blocker therapy (atenolol) versus angiotensin II receptor blocker therapy (Iosartan) in individuals with Marfan syndrome. Am Heart J 2007; 154: 624-631.

472 Hackam DG, Thiruchelvam D, Redelmeier DA. Angiotensin-converting enzyme inhibitors and aortic rupture: a population-based case-control study. Lancet 2006; 368: 659-665. OS

473 MacSweeney ST, Ellis M, Worrell PC, Greenhalgh RM, Powell JT. Smoking and growth rate of small abdominal aortic aneurysms. Lancet 1994; 344: 651-652. RV 
474 Stewart KJ, Hiatt WR, Regensteiner JG, Hirsch AT. Exercise training for claudication. N Engl J Med 2002; 347: 1941-1951. RV

475 Norgren L, Hiatt WR, Dormandy JA, Nehler MR, Harris KA, Fowkes FG. TASC II Working Group. Inter-Society Consensus for the Management of Peripheral Arterial Disease (TASC II). J Vasc Surg 2007; 45 (Suppl S): S5-67. GL

476 Radack K. Deck C. Beta-adrenergic blocker therapy does not worsen intermittent claudication in subjects with peripheral arterial disease. A meta-analysis of randomized controlled trials. Arch Intern Med 1991; 151: 1769-1776. MA

477 limura O. Insulin resistance and hypertension in Japanese. Hypertens Res 1996; 19 : S1-S8. RV

478 American Diabetes Association. Role of cardiovascular risk factors in prevention and treatment of macrovascular disease in diabetes. Diabetes Care 1989; 12: 573-579. GL

479 UK Prospective Diabetes Study Group. Efficacy of atenolol and captopril in reducing risk of macrovascular and microvascular complications in type 2 diabetes: UKPDS 39. BMJ 1998; 317: 713-720. RT

480 Ravid M, Savin H, Jutrin I, Bental T, Katz B, Lishner M. Long-term stabilizing effect of angiotensin-converting enzyme inhibition on plasma creatinine and on proteinuria in normotensive type II diabetic patients. Ann Intern Med 1993; 118: 577-581. RT

481 Expert Committee on the Diagnosis and Classification of Diabetes Mellitus. Report of the expert committee on the diagnosis and classification of diabetes mellitus. Diabetes Care 2002; 25: S5-20. GL

482 Ohnishi H. Saito S, Shimamoto K. Review of Tanno-Sobetsu chou study. Ther Res 2007; 28: 513-525. Japanese. RV

483 limura O, Shimamoto K, Matsuda K, Masuda A, Takizawa H, Higashiura K, Miyazaki Y, Hirata A, Ura N, Nakagawa M. Effects of angiotensin receptor antagonist and angiotensin converting enzyme inhibitor on insulin sensitivity in fructose-fed hypertensive rats and essential hypertensives. Am J Hypertens 1995; 8: 353-357. CT

484 The EUCLID Study Group. Randomised placebo-controlled trial of lisinopril in normotensive patients with insulin-dependent diabetes and normoalbuminuria or microalbuminuria. Lancet 1997; 349: 1787-1792. RT

485 J-MIND REASEARCH GROUP. Comparison of long-term effect of CA antagonist and ACE inhibitor on onset and development of diabetic nephropathy. J Jpn Diabetes Soc 1999; 42: 5225

486 Parving HH, Lehnert H, Bröchner-Mortensen J, Gomis R, Andersen S, Arner P, Irbesartan in Patients with Type 2 Diabetes and Microalbuminuria Study Group. The effect of irbesartan on the development of diabetic nephropathy in patients with type 2 diabetes. N Engl J Med 2001; 345: 870-878. RT

487 Viberti G, Wheeldon NM, MicroAlbuminuria Reduction With VALsartan (MARVAL) Study Investigators. Microalbuminuria reduction with valsartan in patients with type 2 diabetes mellitus: a blood pressure-independent effect. Circulation 2002; 106: 672-678. RT

488 Niskanen L, Hedner T, Hansson L, Lanke J, Niklason A, CAPPP Study Group. Reduced cardiovascular morbidity and mortality in hypertensive diabetic patients on first-line therapy with an ACE inhibitor compared with a diureticb-blocker-based treatment regimen: a subanalysis of the Captopril Prevention Project. Diabetes Care 2001; 24: 2091-2096. RT

489 Tuomilehto J, Rastenyte D, Birkenhäger WH, Thijs L, Antikainen R, Bulpitt CJ, Fletcher AE, Forette F, Goldhaber A, Palatini P, Sarti C, Fagard R, Systolic Hypertension in Europe Trial Investigators. Effects of calcium-channel blockade in older patients with diabetes and systolic hypertension. N Engl J Med 1999; 340: 677-684. RT

490 Estacio RO, Jeffers BW, Hiatt WR, Biggerstaff SL, Gifford N, Schrier RW. The effect of nisoldipine as compared with enalapril on cardiovascular outcomes in patients with non-insulin-dependent diabetes and hypertension. N Engl J Med 1998; 338: 645-652. RT

491 Tatti P, Pahor M, Byington RP, Di Mauro P, Guarisco R, Strollo G, Strollo F. Outcome results of the Fosinopril Versus Amlodipine Cardiovascular Events Randomized Trial (FACET) in patients with hypertension and NIDDM. Diabetes Care 1998; 21: 597-603. RT

492 Leenen FH, Nwachuku CE, Black HR, Cushman WC, Davis BR, Simpson LM, Alderman MH, Atlas SA, Basile JN, Cuyjet AB, Dart R, Felicetta JV, Grimm RH, Haywood LJ, Jafri SZ, Proschan MA, Thadani U, Whelton PK, Wright JT, Antihypertensive and Lipid-Lowering Treatment to Prevent Heart Attack Trial Collaborative Research Group. Clinical events in high-risk hypertensive patients randomly assigned to calcium channel blockerversus angiotensin-converting enzyme inhibitor in the antihypertensive and lipid-lowering treatment to prevent heart attack trial. Hypertension 2006; 48 : 374-384. RT

493 Bakris GL, Toto RD, McCullough PA, Rocha R, Purkayastha D, Davis P, GUARD (Gauging Albuminuria Reduction With Lotrel in Diabetic Patients With Hypertension) Study Investigators. Effects of different ACE inhibitor combinations on albuminuria: results of the GUARD study. Kidney Int 2008; 73: 1303-1309. RT

494 Matsuzaki M, Kita T, Mabuchi H, Matsuzawa Y, Nakaya N, Oikawa S, Saito Y, Sasaki J, Shimamoto K, Itakura H, J-LIT Study Group. Japan Lipid Intervention Trial. Large scale cohort study of the relationship between serum cholesterol concentration and coronary events with low-dose simvastatin therapy in Japanese patients with hypercholesterolemia. Circ J 2002; 66: 1087-1095. OS

495 Sever PS, Dahlöf B, Poulter NR, Wedel H, Beevers G, Caulfield M, Collins R, Kjeldsen SE, Kristinsson A, McInnes GT, Mehlsen J, Nieminen M, O'Brien E, Ostergren J, ASCOT investigators. Prevention of coronary and stroke events with atorvastatin in hypertensive patients who have average or lower-than-average cholesterol concentrations, in the Anglo-Scandinavian Cardiac Outcomes Trial-Lipid Lowering Arm (ASCOTLLA): a multicentre randomised controlled trial. Lancet 2003; 361: 1149-1158. RT
496 The Ministry of Welfare, Japan. Report of the National Nutritional Survey in 1990. Tokyo: Daiichi-Shuppan 1992. Japanese.

497 Expert Panel on Detection, Evaluation, and Treatment of High Blood Cholesterol in Adults. Executive Summary of The Third Report of The National Cholesterol Education Program (NCEP) Expert Panel on Detection, Evaluation, And Treatment of High Blood Cholesterol In Adults (Adult Treatment Panel III). JAMA 2001; 285: 2486-2497. GL

498 Ohnishi H, Saitoh S, Takagi S, Katoh N, Chiba Y, Akasaka H, Nakamura Y, Shimamoto $\mathrm{K}$. Incidence of Type 2 diabetes in individuals with central obesity in a rural Japanese population-The Tanno and Sobetsu Study. Diabetes Care 2006; 29. 1128-1129.

499 Leung RS, Bradley TD. Sleep apnea and cardiovascular disease. Am J Respir Crit Care Med 2001; 164: 2147-2165. RV

500 Eguchi K, Kario K, Hoshide S, Ishikawa J, Morinari M, Shimada K. Nocturnal hypoxia is associated with silent cerebrovascular disease in a high-risk Japanese communitydwelling population. Am J Hypertens 2005; 18: 1489-1495. OS

501 Wolk R, Somers VK. Sleep and the metabolic syndrome. Exp Physiol 2007; 92 : 67-78. RV

502 Sasanabe R, Banno K, Otake K, Hasegawa R, Usui K, Morita M, Shiomi T. Metabolic syndrome in Japanese patients with obstructive sleep apnea syndrome. Hypertens Res 2006; 29: 315-322. OS

503 Shiina K, Tomiyama H, Takata Y, Usui Y, Asano K, Hirayama Y, Nakamura T, Yamashina A. Concurrent presence of metabolic syndrome in obstructive sleep apnea syndrome exacerbates the cardiovascular risk: a sleep clinic cohort study. Hypertens Res 2006; 29: 433-441. OS

504 Endo S, Mataki S, Kurosaki N. Cephalometric evaluation of craniofacial and upper airway structures in Japanese patients with obstructive sleep apnea. J Med Dent Sci 2003; 50: 109-120. OS

505 Sharafkhaneh A, Giray N, Richardson P, Young T, Hirshkowitz M. Association of psychiatric disorders and sleep apnea in a large cohort. Sleep 2005; 28: 1405-1411. OS

506 Wolk R, Shamsuzzaman AS, Somers VK. Obesity, sleep apnea, and hypertension. Hypertension 2003; 42: 1067-1074. RV

507 Umlauf MG, Chasens ER, Greevy RA, Arnold J, Burgio KL, Pillion DJ. Obstructive sleep apnea, nocturia and polyuria in older adults. Sleep 2004; 27: 139-144. OS

508 Logan AG, Perlikowski SM, Mente A, Tisler A, Tkacova R, Niroumand M, Leung RS, Bradley TD. High prevalence of unrecognized sleep apnoea in drug-resistant hypertension. J Hypertens 2001; 19: 2271-2277. OS

509 Somers VK, Dyken ME, Clary MP, Abboud FM. Sympathetic neural mechanisms in obstructive sleep apnea. J Clin Invest 1995; 96: 1897-1904. OS

510 Pickering TG, Kario K. Nocturnal non-dipping: what does it augur? Curr Opin Nephrol Hypertens 2001; 10: 611-616. RV

511 Kishimoto A, Tochikubo 0, Ohshige K. Relation between nocturnal arterial oxygen desaturation and morning blood pressure. Clin Exp Hypertens 2007; 29: 51-60. CT

512 Noda A, Nakata S, Koike Y, Miyata S, Kitaichi K, Nishizawa T, Nagata K, Yasuma F, Murohara T, Yokota M. Continuous positive airway pressure improves daytime baroreflex sensitivity and nitric oxide production in patients with moderate to severe obstructive sleep apnea syndrome. Hypertens Res 2007; 30: 669-676. RT

513 Møller DS, Lind P, Strunge B, Pedersen EB. Abnormal vasoactive hormones and 24-hour blood pressure in obstructive sleep apnea. Am J Hypertens 2003; 16 : 274-280. CT

514 Schulz R, Mahmoudi S, Hattar K, Sibelius U, Olschewski H, Mayer K, Seeger W, Grimminger $F$. Enhanced release of superoxide from polymorphonuclear neutrophils in obstructive sleep apnea. Impact of continuous positive airway pressure therapy. Am J Respir Crit Care Med 2000; 162: 566-570.

515 Yamauchi M, Nakano H, Maekawa J, Okamoto Y, Ohnishi Y, Suzuki T, Kimura H. Oxidative stress in obstructive sleep apnea. Chest 2005; 127: 1674-1679. OS

516 Shamsuzzaman AS, Winnicki M, Lanfranchi P, Wolk R, Kara T, Accurso V, Somers VK. Elevated C-reactive protein in patients with obstructive sleep apnea. Circulation 2002; 105: 2462-2464. CT

517 Phillips BG, Kato M, Narkiewicz K, Choe I, Somers VK. Increases in leptin levels, sympathetic drive, and weight gain in obstructive sleep apnea. Am J Physiol Heart Circ Physiol 2000; 279: H234-H237. CT

518 Ip MS, Lam B, Ng MM, Lam WK, Tsang KW, Lam KS. Obstructive sleep apnea is independently associated with insulin resistance. Am J Respir Crit Care Med 2002; 165: 670-676. OS

519 Shirasaki O, Yamashita S, Kawara S, Tagami K, Ishikawa J, Shimada K, Kario K. A new technique for detecting sleep apnea-related 'midnight' surge of blood pressure. Hypertens Res 2006; 29: 695-702.

520 Amin R, Somers VK, McConnell K, Willging P, Myer C, Sherman M, McPhail G, Morgenthal A, Fenchel M, Bean J, Kimball T, Daniels S. Activity-adjusted 24-hour ambulatory blood pressure and cardiac remodeling in children with sleep disordered breathing. Hypertension 2008; 51: 84-91. CT

521 Bazzano LA, Khan Z, Reynolds K, He J. Effect of nocturnal nasal continuous positive airway pressure on blood pressure in obstructive sleep apnea. Hypertension 2007; 50: 417-423. MA

522 Giles TL, Lasserson TJ, Smith BH, White J, Wright J, Cates CJ. Continuous positive airways pressure for obstructive sleep apnoea in adults. Cochrane Database Syst Rev 2006; 3: CD001106. MA

523 Doherty LS, Kiely JL, Swan V, McNicholas WT. Long-term effects of nasal continuous positive airway pressure therapy on cardiovascular outcomes in sleep apnea syndrome. Chest 2005; 127: 2076-2084. OS 
524 Marin JM, Carrizo SJ, Vicente E, Agusti AG. Long-term cardiovascular outcomes in men with obstructive sleep apnoea-hypopnoea with or without treatment with continuous positive airway pressure: an observational study. Lancet 365: 1046-1053. OS

525 Barbé F, Mayoralas LR, Duran J, Masa JF, Maimó A, Montserrat JM, Monasterio C, Bosch M, Ladaria A, Rubio M, Rubio R, Medinas M, Hernandez L, Vidal S, Douglas NJ, Agustí AG. Treatment with continuous positive airway pressure is not effective in patients with sleep apnea but no daytime sleepiness: a randomized, controlled trial. Ann Intern Med 2001; 134: 1015-1023. RT

526 Robinson GV, Smith DM, Langford BA, Davies RJ, Stradling JR. Continuous positive airway pressure does not reduce blood pressure in nonsleepy hypertensive OSA patients. Eur Respir J 2006; 27: 1229-1235. RT

527 Kraiczi H, Hedner J, Peker Y, Grote L. Comparison of atenolol, amlodipine, enalapril, hydrochlorothiazide, and losartan for antihypertensive treatment in patients with obstructive sleep apnea. Am J Respir Crit Care Med 2000; 161: 1423-1428. RT

528 Pelttari LH, Hietanen EK, Salo TT, Kataja MJ, Kantola IM. Little effect of ordinary antihypertensive therapy on nocturnal high blood pressure in patients with sleep disordered breathing. Am J Hypertens 1998; 11: 272-279. RT

529 Bucca CB, Brussino L, Battisti A, Mutani R, Rolla G, Mangiardi L, Cicolin A. Diuretics in obstructive sleep apnea with diastolic heart failure. Chest 2007; 132: 440-446. OS

530 Cicolin A, Mangiardi L, Mutani R, Bucca C. Angiotensin-converting enzyme inhibitors and obstructive sleep apnea. Mayo Clin Proc 2006; 81: 53-55. OS

531 Hirota SA, Janssen LJ. Sodium and asthma: something borrowed, something new? Am J Physiol Lung Cell Mol Physiol 2007; 293: L1369-L1373.

532 Arai T, Yasuda Y, Toshima S, Yoshimi N, Kashiki Y. ACE inhibitors and pneumonia in elderly people. Lancet 1998; 352: 1937-1938.

533 Okaishi K, Morimoto S, Fukuo K, Niinobu T, Hata S, Onishi T, Ogihara T. Reduction of risk of pneumonia associated with use of angiotensin I converting enzyme inhibitors in elderly inpatients. Am J Hypertens 1999; 12: 778-783. CT

534 Andreas S, Herrmann-Lingen C, Raupach T, Lüthje L, Fabricius JA, Hruska N, Körber W, Büchner B, Criée CP, Hasenfuss G, Calverley P. Angiotensin II blockers in obstructive pulmonary disease: a randomised controlled trial. Eur Respir J 2006; 27: 972-979. RT

535 Cheng JW, Zhu L, Gu MJ, Song ZM. Meta analysis of propranolol effects on gastrointestinal hemorrhage in cirrhotic patients. World J Gastroenterol 2003; 9: 1836-1839. MA

536 Yokohama S, Yoneda M, Haneda M, Okamoto S, Okada M, Aso K, Hasegawa T, Tokusashi Y, Miyokawa N, Nakamura K. Therapeutic efficacy of an angiotensin II receptor antagonist in patients with nonalcoholic steatohepatitis. Hepatology 2004; 40: $1222-1225$. OS

537 Japanese Society of Gout and Nucleic Acid Metabolism. Guideline for the management of hyperuricemia and gout. Japanese Society of Gout and Nucleic Acid Metabolism: Tokyo, 2002, p 79. Japanese. GL

538 Iwanaga T, Sato M, Maeda T, Ogihara T, Tamai I. Concentration-dependent mode of interaction of angiotensin II receptor blockers with uric acid transporter. J Pharmacol Exp Ther 2007; 320: 211-217.

539 Enomoto A, Kimura H, Chairoungdua A, Shigeta Y, Jutabha P, Cha SH, Hosoyamada M, Takeda M, Sekine T, Igarashi T, Matsuo H, Kikuchi Y, Oda T, Ichida K, Hosoya T, Shimokata K, Niwa T, Kanai Y, Endou H. Molecular identification of a renal urate anion exchanger that regulates blood urate levels. Nature 2002; 417: 447-452.

540 Høieggen A, Alderman MH, Kjeldsen SE, Julius S, Devereux RB, De Faire U, Fyhrquist $\mathrm{F}$, Ibsen $\mathrm{H}$, Kristianson K, Lederballe-Pedersen O, Lindholm LH, Nieminen MS, Omvik P, Oparil S, Wedel H, Chen C, Dahlöf B, LIFE Study Group. The impact of serum uric acid on cardiovascular outcomes in the LIFE study. Kidney Int 2004; 65 1041-1049. RT

541 Port S, Demer L, Jennrich R, Walter D, Garfinkel A. Systolic blood pressure and mortality. Lancet 2000; 355: 175-180.

542 Rastas S, Pirttilä T, Viramo P, Verkkoniemi A, Halonen P, Juva K, Niinistö L, Mattila K, Länsimies E, Sulkava R. Association between blood pressure and survival over 9 years in a general population aged 85 and older. J Am Geriatr Soc 2006; 54: 912-918. OS

543 van Bemmel T, Gussekloo J, Westendorp RG, Blauw GJ. In a population-based prospective study, no association between high blood pressure and mortality after age 85 years. J Hypertens 2006; 24: 287-292. OS

544 Fagard RH, Staessen JA, Thijs L, Celis H, Bulpitt CJ, de Leeuw PW, Leonetti G, Tuomilehto J, Yodfat Y. On-treatment diastolic blood pressure and prognosis in systolic hypertension. Arch Intern Med 2007; 167: 1884-1891. OS

545 Ogihara T, Rakugi H. Hypertension in the elderly: a Japanese perspective. Drugs Aging 2005; 22: 297-314. RV

546 Insua JT, Sacks HS, Lau TS, Lau J, Reitman D, Pagano D, Chalmers TC. Drug treatment of hypertension in the elderly: a meta-analysis. Ann Intern Med 1994; 121: 355-362. MA

547 Black HR, Elliott WJ, Weber MA, Frishman WH, Strom JA, Liebson PR, Hwang CT, Ruff DA, Montoro R, DeQuattro V, Zhang D, Schleman MM, Klibaner MI. One-year study of felodipine or placebo for stage 1 isolated systolic hypertension. Hypertension 2001; 38: 1118-1123. RT

548 JATOS Study Group. Principal results of the Japanese trial to assess optimal systolic blood pressure in elderly hypertensive patients (JATOS). Hypertens Res 2008; 31 (in press) RT

549 Perry Jr HM, Davis BR, Price TR, Applegate WB, Fields WS, Guralnik JM, Kuller L, Pressel S, Stamler J, Probstfield JL, Systolic Hypertension in the Elderly Program ( SHEP) Cooperative Research Group. Effect of treating isolated systolic hypertension on the risk of developing various types and subtypes of stroke: the Systolic Hypertension in the Elderly Program (SHEP). JAMA 2000; 284: 465-471. RT

550 Kjeldsen SE, Kolloch RE, Leonetti G, Mallion JM, Zanchetti A, Elmfeldt D, Warnold I, Hansson L. Influence of gender and age on preventing cardiovascular disease by antihypertensive treatment and acetylsalicylic acid. The HOT study. Hypertension Optimal Treatment. J Hypertens 2000; 18: 629-642. RT

551 Somes GW, Pahor M, Shorr RI, Cushman WC, Applegate WB. The role of diastolic blood pressure when treating isolated systolic hypertension. Arch Intern Med 1999; 159: 2004-2009. OS

552 Ogihara T. Practitioner's Trial on the Efficacy of Antihypertensive Treatment in the Elderly Hypertension (The PATE-Hypertension Study) in Japan. Am J Hypertens 2000; 13: 461-467. CT

553 Motoyama M, Sunami Y, Kinoshita F, Kiyonaga A, Tanaka H, Shindo M, Irie T, Urata H, Sasaki J, Arakawa K. Blood pressure lowering effect of low intensity aerobic training in elderly hypertensive patients. Med Sci Sports Exerc 1998; 30: 818-823.

554 Hiwada K, Ogihara T, Matsumoto M, Matsuoka H, Takishita S, Shimamoto K, Toba K, Abe I, Kohara K, Morimoto S, Mikami H, Iwai K, Takasaki M, Kawano Y, Higashiura K, Kozaki K, Eto M, Fujishima M. Guidelines for hypertension in the elderly-1999 revised version. Ministry of Health and Welfare of Japan. Hypertens Res 1999; 22 : 231-259. GL

555 Forette F, Seux ML, Staessen JA, Thijs L, Birkenhäger WH, Babarskiene MR, Babeanu S, Bossini A, Gil-Extremera B, Girerd X, Laks T, Lilov E, Moisseyev V, Tuomilehto J, Vanhanen H, Webster J, Yodfat Y, Fagard R. Prevention of dementia in randomised double-blind placebo-controlled Systolic Hypertension in Europe (Syst-Eur) trial. Lancet 1998; 352: 1347-1351. RT

556 Kjeldsen SE, Dahlöf B, Devereux RB, Julius S, Aurup P, Edelman J, Beevers G, de Faire U, Fyhrquist F, Ibsen H, Kristianson K, Lederballe-Pedersen O, Lindholm LH, Nieminen MS, Omvik P, Oparil S, Snapinn S, Wedel H, LIFE (Losartan Intervention for Endpoint Reduction) Study Group. Effects of losartan on cardiovascular morbidity and mortality in patients with isolated systolic hypertension and left ventricular hypertrophy: a Losartan Intervention for Endpoint Reduction (LIFE) substudy. JAMA 2002; 288: 1491-1498. CT

557 Papademetriou V, Farsang C, Elmfeldt D, Hofman A, Lithell H, Olofsson B, Skoog I, Trenkwalder P, Zanchetti A, Study on Cognition and Prognosis in the Elderly study group. Stroke prevention with the angiotensin II type 1-receptor blocker candesartan in elderly patients with isolated systolic hypertension: the Study on Cognition and Prognosis in the Elderly (SCOPE). J Am Coll Cardiol 2004; 44: 1175-1180. CT

558 Wing LM, Reid CM, Ryan P, Beilin LJ, Brown MA, Jennings GL, Johnston CI, McNeil JJ, Macdonald GJ, Marley JE, Morgan TO, West MJ, Second Australian National Blood Pressure Study Group. A comparison of outcomes with angiotensin-convertingenzyme inhibitors and diuretics for hypertension in the elderly. N Engl J Med 2003; 348: 583-592. RT

559 Turnbull F, Neal B, Ninomiya T, Algert C, Arima H, Barzi F, Bulpitt C, Chalmers J, Fagard R, Gleason A, Heritier S, Li N, Perkovic V, Woodward M, MacMahon S, Blood Pressure Lowering Treatment Trialists' Collaboration. Effects of different regimens to lower blood pressure on major cardiovascular events in older and younger adults: meta-analysis of randomised trials. BMJ 2008; 336: 1121-1123. MA

560 Berthet K, Neal BC, Chalmers JP, MacMahon SW, Bousser MG, Colman SA, Woodward $M$, Perindopril Protection Against Recurrent Stroke Study Collaborative Group. Reductions in the risks of recurrent stroke in patients with and without diabetes: the PROGRESS Trial. Blood Press 2004; 13: 7-13. RT

561 Lindholm LH, Hansson L, Ekbom T, Dahlöf B, Lanke J, Linjer E, Scherstén B, Wester PO, Hedner T, de Faire U, STOP Hypertension-2 Study Group. Comparison of antihypertensive treatments in preventing cardiovascular events in elderly diabetic patients: results from the Swedish Trial in Old Patients with Hypertension-2. J Hypertens 2000; 18: 1671-1675. RT

562 Mancia G, Brown M, Castaigne A, de Leeuw P, Palmer CR, Rosenthal T, Wagener G, Ruilope LM, INSIGHT. Outcomes with nifedipine GITS or Co-amilozide in hypertensive diabetics and nondiabetics in Intervention as a Goal in Hypertension (INSIGHT). Hypertension 2003; 41: 431-436. RT

563 Whelton PK, Barzilay J, Cushman WC, Davis BR, liamathi E, Kostis JB, Leenen FH, Louis GT, Margolis KL, Mathis DE, Moloo J, Nwachuku C, Panebianco D, Parish DC, Pressel S, Simmons DL, Thadani U, ALLHAT Collaborative Research Group. Clinical outcomes in antihypertensive treatment of type 2 diabetes, impaired fasting glucose concentration, and normoglycemia: Antihypertensive and Lipid-Lowering Treatment to Prevent Heart Attack Trial (ALLHAT). Arch Intern Med 2005; 165: 1401-1409. RT

564 Khan NA, Hemmelgarn B, Padwal R, Larochelle P, Mahon JL, Lewanczuk RZ, McAlister FA, Rabkin SW, Hill MD, Feldman RD, Schiffrin EL, Campbell NR, Logan AG, Arnold M, Moe G, Campbell TS, Milot A, Stone JA, Jones C, Leiter LA, Ogilvie RI, Herman RJ, Hamet P, Fodor G, Carruthers G, Culleton B, Burns KD, Ruzicka M, deChamplain J, Pylypchuk G, Gledhill N, Petrella R, Boulanger JM, Trudeau L, Hegele RA, Woo V, McFarlane P, Touyz RM, Tobe SW, Canadian Hypertension Education Program. The 2007 Canadian Hypertension Education Program recommendations for the management of hypertension: part 2-therapy. Can J Cardiol 2007; 23: 539-550. GL

565 Mosca L, Banka CL, Benjamin EJ, Berra K, Bushnell C, Dolor RJ, Ganiats TG, Gomes AS, Gornik HL, Gracia C, Gulati M, Haan CK, Judelson DR, Keenan N, Kelepouris E, Michos ED, Newby LK, Oparil S, Ouyang P, Oz MC, Petitti D, Pinn VW, Redberg RF, Scott R, Sherif K, Smith Jr SC, Sopko G, Steinhorn RH, Stone NJ, Taubert KA, Todd BA, Urbina E, Wenger NK, Expert Panel/Writing Group. Evidence-based guidelines for cardiovascular disease prevention in women: 2007 update. J Am Coll Cardiol 2007; 49: 1230-1250. GL 
566 Garovic VD, Hayman SR. Hypertension in pregnancy: an emerging risk factor for cardiovascular disease. Nat Clin Pract Nephrol 2007; 3: 613-622. RV

567 The Guideline Committee of the Japanese Society of Obstetrics \& Gynecology for Perinatal Medicine. Definition and classification of pregnacy-induced hypertension. Nippon Sanka Fujinka Gakkai Zasshi 2004; 56: 12-13. Japanese

568 Waugh J, Perry IJ, Halligan AW, De Swiet M, Lambert PC, Penny JA, Taylor DJ, Jones DR, Shennan A. Birth weight and 24-hour ambulatory blood pressure in nonproteinuric hypertensive pregnancy. Am J Obstet Gynecol 2000; 183: 633-637. OS

569 Abalos E, Duley L, Steyn DW, Henderson-Smart DJ. Antihypertensive drug therapy for mild to moderate hypertension during pregnancy. Cochrane Database Syst Rev 2001 CD002252. RV

570 Sibai B, Dekker G, Kupferminc M. Pre-eclampsia. Lancet 2005; 365: 785-799. RV

571 Sibai BM. Chronic hypertension in pregnancy. Obstet Gynecol 2002; 100: 369-377. RV

572 von Dadelszen P, Magee LA. Fall in mean arterial pressure and fetal growth restriction in pregnancy hypertension: an updated metaregression analysis. J Obstet Gynaecol Can 2002; 24: 941-945. MA

573 Jones DC, Hayslett JP. Outcome of pregnancy in women with moderate or severe renal insufficiency. N Engl J Med 1996; 335: 226-232. OS

574 Churchill D, Duley L. Interventionist versus expectant care for severe pre-eclampsia before term. Cochrane Database Syst Rev 2002 CD003106. RV

575 von Dadelszen P, Menzies J, Gilgoff S, Xie F, Douglas MJ, Sawchuck D, Magee LA. Evidence-based management for preeclampsia. Front Biosci 2007; 12: 2876-2889. RV

576 Aali BS, Nejad SS. Nifedipine or hydralazine as a first-line agent to control hypertension in severe preeclampsia. Acta Obstet Gynecol Scand 2002; 81: 25-30. RT

577 Montán S. Drugs used in hypertensive diseases in pregnancy. Curr Opin Obstet Gynecol 2004; 16: 111-115. RV

578 Shotan A, Widerhorn J, Hurst A, Elkayam U. Risks of angiotensin-converting enzyme inhibition during pregnancy: experimental and clinical evidence, potential mechanisms, and recommendations for use. Am J Med 1994; 96: 451-456. MA

579 From the Centers for Disease Control and Prevention. Postmarketing surveillance for angiotensin-converting enzyme inhibitor use during the first trimester of pregnancyUnited States, Canada, and Israel, 1987-1995. JAMA 1997; 277: 1193-1194.

580 Churchill D, Beevers GD, Meher S, Rhodes C. Diuretics for preventing pre-eclampsia. Cochrane Database Syst Rev 2007 CD004451. RV

581 Duley L, Henderson-Smart DJ, Meher S, King JF. Antiplatelet agents for preventing pre-eclampsia and its complications. Cochrane Database Syst Rev 2007 CD004659. MA

582 Duley L, Gülmezoglu AM, Henderson-Smart DJ. Magnesium sulphate and other anticonvulsants for women with pre-eclampsia. Cochrane Database Syst Rev 2003 CD000025. RV

583 Briggs GG, Freeman RK, Yaffe SJ. Drugs in Pregnancy and Lactation, 8th edn. Lippincott Williams \& Wilkins: Philadelphia, 2008.

584 Reckelhoff JF, Fortepiani LA. Novel mechanisms responsible for postmenopausal hypertension. Hypertension 2004; 43: 918-923. RV

585 Beale CM, Collins P. The menopause and the cardiovascular system. Baillieres Clin Obstet Gynaecol 1996; 10: 483-513. RV

586 Oparil S. Hypertension in postmenopausal women: pathophysiology and management. Curr Opin Nephrol Hypertens 1995; 4: 438-442. RV

587 Staessen JA, Celis H, Fagard R. The epidemiology of the association between hypertension and menopause. J Hum Hypertens 1998; 12: 587-592. RV

588 Pines A, Fisman EZ. Hypertension in menopausal women-a special case, for special treatment? Gynecol Endocrinol 2001; 15: 397-405. RV

589 Rossouw JE, Anderson GL, Prentice RL, LaCroix AZ, Kooperberg C, Stefanick ML, Jackson RD, Beresford SA, Howard BV, Johnson KC, Kotchen JM, Ockene J, Writing Group for the Women's Health Initiative Investigators. Risks and benefits of estrogen plus progestin in healthy postmenopausal women: principal results From the Women's Health Initiative randomized controlled trial. JAMA 2002; 288: 321-333. RT

590 Chasan-Taber L, Willett WC, Manson JE, Spiegelman D, Hunter DJ, Curhan G, Colditz GA, Stampfer MJ. Prospective study of oral contraceptives and hypertension among women in the United States. Circulation 1996; 94: 483-489. OS

591 Anderson GL, Limacher M, Assaf AR, Bassford T, Beresford SA, Black H, Bonds D, Brunner R, Brzyski R, Caan B, Chlebowski R, Curb D, Gass M, Hays J, Heiss G, Hendrix S, Howard BV, Hsia J, Hubbell A, Jackson R, Johnson KC, Judd H, Kotchen JM, Kuller L, LaCroix AZ, Lane D, Langer RD, Lasser N, Lewis CE, Manson J, Margolis K, Ockene J, O'Sullivan MJ, Phillips L, Prentice RL, Ritenbaugh C, Robbins J, Rossouw JE, Sarto G, Stefanick ML, Van Horn L, Wactawski-Wende J, Wallace R, Wassertheil-Smoller S, Women's Health Initiative Steering Committee. Effects of conjugated equine estrogen in postmenopausal women with hysterectomy: the Women's Health Initiative randomized controlled trial. JAMA 2004; 291: 1701-1712. RT

592 Miller JA, Cherney DZ, Duncan JA, Lai V, Burns KD, Kennedy CR, Zimpelmann J, Gao W, Cattran DC, Scholey JW. Gender differences in the renal response to reninangiotensin system blockade. J Am Soc Nephrol 2006; 17: 2554-2560. CT

593 Tominaga T, Suzuki H, Ogata Y, Matsukawa S, Saruta T. The role of sex hormones and sodium intake in postmenopausal hypertension. J Hum Hypertens 1991; 5: 495-500.

594 Fernández-Vega F, Abellán J, Vegazo O, García de Vinuesa S, Rodríguez JC, Maceira B, Sanz de Castro S, Robles NR, Luño J. Angiotensin II type 1 receptor blockade to control blood pressure in postmenopausal women: influence of hormone replacement therapy. Kidney Int 2002; 62 (Suppl 82): 36-41. OS
595 Deroo BJ, Korach KS. Estrogen receptors and human disease. J Clin Invest 2006; 116: 561-570. RV

596 Ray JG, Vermeulen MJ, Schull MJ, Redelmeier DA. Cardiovascular health after maternal placental syndromes (CHAMPS): population-based retrospective cohort study. Lancet 2005; 366: 1797-1803. OS

597 Suzuki H, Watanabe Y, Arima H, Kobayashi K, Ohno Y, Kanno Y. Short- and long-term prognosis of blood pressure and kidney disease in women with a past history of preeclampsia. Clin Exp Nephrol 2008; 12: 102-109. RV

598 National High Blood Pressure Education Program Working Group on High Blood Pressure in Children and Adolescents. The fourth report on the diagnosis, evaluation, and treatment of high blood pressure in children and adolescents. Pediatrics 2004; 114: 555-576. GL

599 Uchiyama M. Topics and issues of pediatric hypertension. J Child Health 2005; 64 : 729-736. Japanese

600 Kikuchi T, Nagasaki K, Hiura M, Ogawa Y, Tanaka Y, Uchiyama M. Epidemiological approach to the childhood obesity. J Japan Society for the Study of Obesity 2004; 10: 12-17. Japanese.

601 Hashimoto N, Kawasaki T, Kikuchi T, Takahashi H, Uchiyama M. The relationship between the intrauterine environment and blood pressure in 3-year-old Japanese children. Acta Paediatr 1996; 85: 132-138.

602 Miura K, Nakagawa H, Tabata M, Morikawa Y, Nishijo M, Kagamimori S. Birth weight, childhood growth, and cardiovascular disease risk factors in Japanese aged 20 years. Am J Epidemiol 2001; 153: 783-789. OS

603 Abe Y, Kikuchi T, Nagasaki K, Hiura M, Tanaka Y, Ogawa Y, Uchiyama M. Lower birth weight associated with current overweight status is related with the metabolic syndrome in obese Japanese children. Hypertens Res 2007; 30: 627-634. OS

604 Stabouli S, Kotsis V, Zakopoulos N. Ambulatory blood pressure monitoring and target organ damage in pediatrics. J Hypertens 2007; 25: 1979-1986. RV

605 Uchiyama M. Risk factors for the development of essential hypertension: long-term follow-up study in junior high school students in Niigata, Japan. J Hum Hypertens 1994; 8: 323-325. OS

606 Kawasaki T, Uezono K, Sanefuji M, Utsunomiya H, Fujino T, Kanaya S, Babazono A. A 17-year follow-up study of hypertensive and normotensive male university students in Japan. Hypertens Res 2003; 26: 445-452. CT

607 Bao W, Threefoot SA, Srinivasan SR, Berenson GS. Essential hypertension predicted by tracking of elevated blood pressure from childhood to adulthood: the Bogalusa Heart Study. Am J Hypertens 1995; 8: 657-665. OS

608 Pickering TG, Shimbo D, Haas D. Ambulatory blood-pressure monitoring. N Engl J Med 2006; 354: 2368-2374. RV

609 Mancia G, Facchetti R, Bombelli M, Grassi G, Sega R. Long-term risk of mortality associated with selective and combined elevation in office, home, and ambulatory blood pressure. Hypertension 2006; 47: 846-853. OS

610 Kario K. Clinician?s manual on early morning risk management in hypertension. Science Press: London, 2004, pp 1-68.

611 Obara T, Ohkubo T, Kikuya M, Asayama K, Metoki H, Inoue R, Oikawa T, Komai R, Murai K, Horikawa T, Hashimoto J, Totsune K, Imai Y, J-HOME Study Group. Prevalence of masked uncontrolled and treated white-coat hypertension defined according to the average of morning and evening home blood pressure value: from the Japan Home versus Office Measurement Evaluation Study. Blood Press Monit 2005; 10: 311-316. OS

612 Tomiyama M, Horio T, Yoshii M, Takiuchi S, Kamide K, Nakamura S, Yoshihara F, Nakahama H, Inenaga T, Kawano Y. Masked hypertension and target organ damage in treated hypertensive patients. Am J Hypertens 2006; 19: 880-886. OS

613 Matsui Y, Eguchi K, Ishikawa J, Hoshide S, Shimada K, Kario K. Subclinical arterial damage in untreated masked hypertensive subjects detected by home blood pressure measurement. Am J Hypertens 2007; 20: 385-391. CT

614 Björklund K, Lind L, Zethelius B, Andrén B, Lithell H. Isolated ambulatory hypertension predicts cardiovascular morbidity in elderly men. Circulation 2003; 107: 1297-1302. OS

615 Ishikawa J, Kario K, Eguchi K, Morinari M, Hoshide S, Ishikawa S, Shimada K, J-MORE Group. Regular alcohol drinking is a determinant of masked morning hypertension detected by home blood pressure monitoring in medicated hypertensive patients with well-controlled clinic blood pressure: the Jichi Morning Hypertension Research (J-MORE) study. Hypertens Res 2006; 29: 679-686. OS

616 Mallion JM, Clerson P, Bobrie G, Genes N, Vaisse B, Chatellier G. Predictive factors for masked hypertension within a population of controlled hypertensives. J Hypertens 2006; 24: 2365-2370. OS

617 Takagi T, Ohishi M, Ito N, Kaibe M, Tatara Y, Terai M, Shiota A, Hayashi N, Rakugi H, Ogihara T. Evaluation of morning blood pressure elevation and autonomic nervous activity in hypertensive patients using wavelet transform of heart rate variability. Hypertens Res 2006; 29: 977-987. OS

618 Gosse P, Lasserre R, Minifié C, Lemetayer P, Clementy J. Blood pressure surge on rising. J Hypertens 2004; 22: 1113-1118. OS

619 Kuwajima I, Mitani K, Miyao M, Suzuki Y, Kuramoto K, Ozawa T. Cardiac implications of the morning surge in blood pressure in elderly hypertensive patients: relation to arising time. Am J Hypertens 1995; 8: 29-33. OS

620 Polónia J, Amado P, Barbosa L, Nazaré J, Silva JA, Bertoquini S, Martins L, Carmona J. Morning rise, morning surge and daytime variability of blood pressure and cardiovascular target organ damage. A cross-sectional study in 743 subjects. Rev Port Cardiol 2005; 24: 65-78. OS

621 Marfella R, Siniscalchi M, Portoghese M, Di Filippo C, Ferraraccio F, Schiattarella C, Crescenzi B, Sangiuolo P, Ferraro G. Siciliano S, Cinone F, Mazzarella G, Martis S, Verza M, Coppola L, Rossi F, D'Amico M, Paolisso G. Morning blood pressure surge as 
a destabilizing factor of atherosclerotic plaque: role of ubiquitin-proteasome activity. Hypertension 2007; 49: 784-791.

622 Shibuya Y, Ikeda T, Gomi T. Morning rise of blood pressure assessed by home blood pressure monitoring is associated with left ventricular hypertrophy in hypertensive patients receiving long-term antihypertensive medication. Hypertens Res 2007; 30: 903-911. OS

623 Murakami S, Otsuka K, Kubo Y, Shinagawa M, Yamanaka T, Ohkawa S, Kitaura Y. Repeated ambulatory monitoring reveals a Monday morning surge in blood pressure in a community-dwelling population. Am J Hypertens 2004; 17: 1179-1183. OS

624 Nagai M, Hoshide S, Ishikawa J, Shimada K, Kario K. Ambulatory blood pressure as an independent determinant of brain atrophy and cognitive function in elderly hypertension. J Hypertens 2008; 26: 1636-1641. OS

625 Hoshide S, Ishikawa J, Eguchi K, Ojima T, Shimada K, Kario K. Masked nocturnal hypertension and target organ damage in hypertensives with well-controlled selfmeasured home blood pressure. Hypertens Res 2007; 30: 143-149. OS

626 Li Y, Staessen JA, Lu L, Li LH, Wang GL, Wang JG. Is isolated nocturnal hypertension a novel clinical entity? Findings from a Chinese population study. Hypertension 2007; 50: 333-339. OS

627 Uzu T, Kimura G. Diuretics shift circadian rhythm of blood pressure from nondipper to dipper in essential hypertension. Circulation 1999; 100: 1635-1638. CT

628 Hermida RC, Ayala DE, Fernández JR, Calvo C. Chronotherapy improves blood pressure control and reverts the nondipper pattern in patients with resistant hypertension. Hypertension 2008; 51: 69-76. RT

629 Kario K, James GD, Marion R, Ahmed M, Pickering TG. The influence of workand home-related stress on the levels and diurnal variation of ambulatory blood pressure and neurohumoral factors in employed women. Hypertens Res 2002; 25: 499-506. OS

630 Yamasaki F, Schwartz JE, Gerber LM, Warren K, Pickering TG. Impact of shift work and race/ethnicity on the diurnal rhythm of blood pressure and catecholamines. Hypertension 1998; 32: 417-423. OS

631 Kaplan NM. Hypertensive crises. In: Kaplan's Clinical Hypertension, 9th edn. Lippincott Williams \& Wilkins: Baltimore, 2006, pp 311-324.

632 Rosei EA, Salvetti M, Farsang C. European Society of Hypertension Scientific Newsletter: treatment of hypertensive urgencies and emergencies. J Hypertens 2006; 24: 2482-2485. RV

633 Vaughan CJ, Delanty N. Hypertensive emergencies. Lancet 2000; 356: 411-417. RV

634 JCS Joint Working Groups for Guidelines for Diagnosis and Treatment of Cardiovascular Diseases. Guidelines for Treatment of Acute Heart Failure (JCS 2006). http://www.j-circ.or.jp/guideline/pdf/JCS2006_maruyama_h.pdf GL

635 Sesoko S, Akema N, Matsukawa T, Kaneko Y. Predisposing factors for the development of malignant essential hypertension. Arch Intern Med 1987; 147: 1721-1724. CT

636 Ohta Y, Tsuchihashi T, Ohya Y, Fujii K. Hirakata H, Abe I, Fujishima M. Trends in the pathophysiological characteristics of malignant hypertension. Hypertens Res 2001; 24: 489-492. CT

637 Kawazoe N, Eto T, Abe I, Takishita S, Ueno M, Kobayashi K, Uezono K, Muratani H, Kimura Y, Tomita Y. Long-term prognosis of malignant hypertension; difference between underlying diseases such as essential hypertension and chronic glomerulonephritis. Clin Nephrol 1988; 29: 53-57. OS

638 Kaplan NM. Functional somatic disease. In: Clinical Hypertension, 9th edn. Lippincott Williams \& Wilkins: Baltimore, 2006, pp 451-453.

639 Mann SJ. Severe paroxysmal hypertension (pseudopheochromocytoma): understanding the cause and treatment. Arch Intern Med 1999; 159: 670-674. OS

640 Fleisher LA, Beckman JA, Brown KA, Calkins H, Chaikof E, Fleischmann KE, Freeman WK, Froehlich JB, Kasper EK, Kersten JR, Riegel B, Robb JF, Smith Jr SC, Jacobs AK, Adams CD, Anderson JL, Antman EM, Buller CE, Creager MA, Ettinger SM, Faxon DP, Fuster V, Halperin JL, Hiratzka LF, Hunt SA, Lytle BW, Nishimura R, Ornato JP, Page RL, Tarkington LG, Yancy CW. American College of Cardiology/American Heart Association Task Force on Practice Guidelines (Writing Committee to Revise the 2002 Guidelines on Perioperative Cardiovascular Evaluation for Noncardiac Surgery). ACC/AHA 2007 guidelines on perioperative cardiovascular evaluation and care for noncardiac surgery: a report of the American College of Cardiology/American Heart Association Task Force on Practice Guidelines (Writing Committee to Revise the 2002 Guidelines on Perioperative Cardiovascular Evaluation for Noncardiac Surgery): developed in collaboration with the American Society of Echocardiography, American Society of Nuclear Cardiology, Heart Rhythm Society, Society of Cardiovascular Anesthesiologists, Society for Cardiovascular Angiography and Interventions, Society for Vascular Medicine and Biology, and Society for Vascular Surgery. Circulation 2007; 116: e418-e499. GL

641 Herman WW, Konzelman JL, Prisant LM. Joint National Committee on Prevention, Detection, Evaluation, and Treatment of High Blood Pressure. New national guidelines on hypertension: a summary for dentistry. J Am Dent Assoc 2004; 135: 576-584. GL

642 Tsuchihashi T, Takata Y, Kurokawa H, Miura K, Maruoka Y, Kajiyama M, Fujishima M. Blood pressure response during dental surgery. Hypertens Res 1996; 19: 189-194. OS

643 Rossi GP, Bernini G, Caliumi C, Desideri G, Fabris B, Ferri C, Ganzaroli C, Giacchetti G, Letizia C, Maccario M, Mallamaci F, Mannelli M, Mattarello MJ, Moretti A, Palumbo G, Parenti G, Porteri E, Semplicini A, Rizzoni D, Rossi E, Boscaro M, Pessina AC, Mantero F, PAPY Study Investigators. A prospective study of the prevalence of primary aldosteronism in 1,125 hypertensive patients. J Am Coll Cardiol 2006; 48: 22932300. OS
644 Nishikawa T, Saito J, Omura M. Prevalence of primary aldosteronism: should we screen for primary aldosteronism before treating hypertensive patients with medication? Endocr J 2007; 54: 487-495. RV

645 Omae T. Pathophysiology and fate of hypertensive subjects. Nippon Naika Gakkai Zasshi 1985; 74: 401-415. Japanese.

646 Berglund G, Andersson O, Wilhelmsen L. Prevalence of primary and secondary hypertension: studies in a random population sample. $\mathrm{Br}$ Med $J$ 1976; 2: 554-556. OS

647 Sinclair AM, Isles CG, Brown I, Cameron H, Murray GD, Robertson JW. Secondary hypertension in a blood pressure clinic. Arch Intern Med 1987; 147: 1289-1293. OS

648 Kimura G, Brenner BM. The renal basis for salt sensitivity in hypertension. In: Laragh JH \& Brenner BM (eds). Hypertension: Pathophysiology, Diagnosis and Management, 2nd edn. Raven Press: New York, 1995, pp 1569-1588.

649 Kimura G. Glomerular function reserve and sodium sensitivity. Clin Exp Nephrol 2005; 9: 102-113. RV

650 Usami T, Koyama K, Takeuchi 0, Morozumi K, Kimura G. Regional variations in the incidence of end-stage renal failure in Japan. JAMA 2000; 284: 2622-2624. OS

651 Usami T, Sato R, Yoshida A, Kimura G. Regional variation in end-stage renal disease. Curr Opin Nephrol Hypertens 2002; 11: 343-346. RV

652 Usami T, Nakao N, Fukuda M, Takeuchi O, Kamiya Y, Yoshida A, Kimura G. Maps of end-stage renal disease and amounts of angiotensin-converting enzyme inhibitors prescribed in Japan. Kidney Int 2003; 64: 1445-1449. OS

653 Blythe WB. Natural history of hypertension in renal parenchymal disease. Am J Kidney Dis 1985; 5: A50-A56. RV

654 Konishi Y, Imanishi M, Okamura M, Yoshioka K, Okumura M, Okada N, Tanaka S, Fujii $\mathrm{S}$, Kimura G. Relationship of renal histological damage to glomerular hypertension in patients with immunoglobulin A nephropathy. J Hypertens 2000; 18: 103-109.

655 Preston RA, Singer I, Epstein M. Renal Parenchymal Hypertension: current concepts of pathogenesis and management. Arch Intern Med 1996; 156: 602-611. RV

656 Wilmer WA, Rovin BH, Hebert CJ, Rao SV, Kumor K, Hebert LA. Management of glomerular proteinuria: a commentary. J Am Soc Nephrol 2003; 14: 3217-3232. RV

657 Maschio G, Cagnoli L, Claroni F, Fusaroli M, Rugiu C, Sanna G, Sasdelli M, Zuccalà A, Zucchelli P. ACE inhibition reduces proteinuria in normotensive patients with IgA nephropathy: a multicentre, randomized, placebo-controlled study. Nephrol Dial Transplant 1994; 9: 265-269. RT

658 Jacobson SH, Eklöf O, Eriksson CG, Lins LE, Tidgren B, Winberg J. Development of hypertension and uraemia after pyelonephritis in childhood: 27 year follow up. BMJ 1989; 299: 703-706. OS

659 Kincaid-Smith P. Glomerular lesions in atrophic pyelonephritis and reflux nephropathy. Kidney Int Supp/ 1975; 4: S81-S83.

660 Guidelines For Diagnosis And Treatment Of Autosomal Dominant Polycystic Kidney Disease. 2nd. In Polycystic Kidney Disease. Intermedica: Tokyo, 2006, 293-313. Japanese. GL

661 Mizoguchi M, Tamura T, Yamaki A, Higashihara E, Shimizu Y. Genotypes of autosomal dominant polycystic kidney disease in Japanese. J Hum Genet 2002; 47: 51-54.

662 Higashihara E, Nutahara K, Kojima M, Tamakoshi A, Yoshiyuki O, Sakai H, Kurokawa $\mathrm{K}$. Prevalence and renal prognosis of diagnosed autosomal dominant polycystic kidney disease in Japan. Nephron 1998; 80: 421-427.

663 Higashihara E, Aso Y, Shimazaki J, Ito H, Koiso K, Sakai O. Clinical aspects of polycystic kidney disease. J Urol 1992; 147: 329-332.

664 Kelleher CL, McFann KK, Johnson AM, Schrier RW. Characteristics of hypertension in young adults with autosomal dominant polycystic kidney disease compared with the general U.S. population. Am J Hypertens 2004; 17: 1029-1034. OS

665 Chapman AB, Johnson A, Gabow PA, Schrier RW. The renin-angiotensin-aldosterone system and autosomal dominant polycystic kidney disease. N Engl J Med 1990; 323: 1091-1096. OS

666 Maschio G, Alberti D, Janin G, Locatelli F, Mann JF, Motolese M, Ponticelli C, Ritz E, Zucchelli $P$, The Angiotensin-Converting-Enzyme Inhibition in Progressive Renal Insufficiency Study Group. Effect of the angiotensin-converting-enzyme inhibitor benazepril on the progression of chronic renal insufficiency. N Engl J Med 1996; 334: 939-945. RT

667 Ecder T, Chapman AB, Brosnahan GM, Edelstein CL, Johnson AM, Schrier RW. Effect of antihypertensive therapy on renal function and urinary albumin excretion in hypertensive patients with autosomal dominant polycystic kidney disease. $\mathrm{Am} \mathrm{J}$ Kidney Dis 2000; 35: 427-432. RT

668 van Dijk MA, Breuning MH, Duiser R, van Es LA, Westendorp RG. No effect of enalapril on progression in autosomal dominant polycystic kidney disease. Nephrol Dial Transplant 2003; 18: 2314-2320. RT

669 Jafar TH, Stark PC, Schmid CH, Strandgaard S, Kamper AL, Maschio G, Becker G, Perrone RD, ACE Inhibition in Progressive Renal Disease (AIPRD) Study Group. The effect of angiotensin-converting-enzyme inhibitors on progression of advanced polycystic kidney disease. Kidney Int 2005; 67: 265-271. MA

670 Nutahara K, Higashihara E, Horie S, Kamura K, Tsuchiya K, Mochizuki T, Hosoya T, Nakayama T, Yamamoto N, Higaki Y, Shimizu T. Calcium channel blocker versus angiotensin II receptor blocker in autosomal dominant polycystic kidney disease. Nephron Clin Pract 2005; 99: c18-c23. RT

671 Schrier R, McFann K, Johnson A, Chapman A, Edelstein C, Brosnahan G, Ecder T, Tison L. Cardiac and renal effects of standard versus rigorous blood pressure control in autosomal-dominant polycystic kidney disease: results of a seven-year prospective randomized study. J Am Soc Nephrol 2002; 13: 1733-1739. RT

672 Klahr S, Breyer JA, Beck GJ, Dennis VW, Hartman JA, Roth D, Steinman TI, Wang SR, Yamamoto ME, Modification of Diet in Renal Disease Study Group. Dietary protein 
restriction, blood pressure control, and the progression of polycystic kidney disease. J Am Soc Nephrol 1995; 5: 2037-2047. RT

673 Safian RD, Textor SC. Renal-artery stenosis. N Engl J Med 2001; 344: 431-442. RV

674 Uzu T, Inoue T, Fujii T, Nakamura S, Inenaga T, Yutani C, Kimura G. Prevalence and predictors of renal artery stenosis in patients with myocardial infarction. Am J Kidney Dis 1997; 29: 733-738. OS

675 Kuroda S, Nishida N, Uzu T, Takeji M, Nishimura M, Fujii T, Nakamura S, Inenaga T, Yutani C, Kimura G. Prevalence of renal artery stenosis in autopsy patients with stroke. Stroke 2000; 31: 61-65. OS

676 Yamashita T, Ito F, Iwakiri N, Mitsuyama H, Fujii S, Kitabatake A. Prevalence and predictors of renal artery stenosis in patients undergoing cardiac catheterization. Hypertens Res 2002; 25: 553-557. OS

677 Nakamura S, lihara K, Matayoshi T, Yasuda H, Yoshihara F, Kamide K, Horio T, Miyamoto $\mathrm{S}$, Kawano $\mathrm{Y}$. The incidence and risk factors of renal artery stenosis in patients with severe carotid artery stenosis. Hypertens Res 2007; 30: 839-844. OS

678 Preston RA, Epstein M. Ischemic renal disease: an emerging cause of chronic renal failure and end-stage renal disease. J Hypertens 1997; 15: 1365-1377. RV

679 Olin JW, Piedmonte MR, Young JR, DeAnna S, Grubb M, Childs MB. The utility of duplex ultrasound scanning of the renal arteries for diagnosing significant renal artery stenosis. Ann Intern Med 1995; 122: 833-838. CT

680 Radermacher J, Chavan A, Bleck J, Vitzthum A, Stoess B, Gebel MJ, Galanski M, Koch $\mathrm{KM}$, Haller H. Use of Doppler ultrasonography to predict the outcome of therapy for renal-artery stenosis. N Engl J Med 2001; 344: 410-417. OS

681 Vasbinder GB, Nelemans PJ, Kessels AG, Kroon AA, de Leeuw PW, van Engelshoven $J M$. Diagnostic tests for renal artery stenosis in patients suspected of having renovascular hypertension: a meta-analysis. Ann Intern Med 2001; 135: 401-411. MA

682 Tegtmeyer CJ, Selby JB, Hartwell GD, Ayers C, Tegtmeyer V. Results and complications of angioplasty in fibromuscular disease. Circulation 1991; 83: I155-I161.

683 Alhadad A, Mattiasson I, Ivancev K, Gottsäter A, Lindblad B. Revascularisation of renal artery stenosis caused by fibromuscular dysplasia: effects on blood pressure during 7-year follow-up are influenced by duration of hypertension and branch artery stenosis. J Hum Hypertens 2005; 19: 761-767.

684 Bonelli FS, McKusick MA, Textor SC, Kos PB, Stanson AW, Johnson CM, Sheedy II PF, Welch TJ, Schirger A. Renal artery angioplasty: technical results and clinical outcome in 320 patients. Mayo Clin Proc 1995; 70: 1041-1052.

685 Zeller T, Frank U, Müller C, Bürgelin K, Sinn L, Bestehorn HP, Cook-Bruns N, Neumann FJ. Predictors of improved renal function after percutaneous stent-supported angioplasty of severe atherosclerotic ostial renal artery stenosis. Circulation 2003; 108: 2244-2249. CT

686 van Jaarsveld BC, Krijnen P, Pieterman H, Derkx FH, Deinum J, Postma CT, Dees A, Woittiez AJ, Bartelink AK, Man in 't Veld AJ, Schalekamp MA, Dutch Renal Artery Stenosis Intervention Cooperative Study Group. The effect of balloon angioplasty on hypertension in atherosclerotic renal-artery stenosis. N Engl J Med 2000; 342: 1007-1014. OS

687 Balk E, Raman G, Chung M, Ip S, Tatsioni A, Alonso A, Chew P, Gilbert SJ, Lau J. Effectiveness of management strategies for renal artery stenosis: a systematic review. Ann Intern Med 2006; 145: 901-912. RV

688 Nordmann AJ, Logan AG. Balloon angioplasty versus medical therapy for hypertensive patients with renal artery obstruction. Cochrane Database Syst Rev 2003: CD002944. RV

689 Martin LG, Rundback JH, Sacks D, Cardella JF, Rees CR, Matsumoto AH, Meranze SG, Schwartzberg MS, Silverstein MI, Lewis CA, Society of Interventional Radiology Standards of Practice Committee. Quality improvement guidelines for angiography, angioplasty, and stent placement in the diagnosis and treatment of renal artery stenosis in adults. J Vasc Interv Radiol 2003; 14: S297-S310. GL

690 Williams JS, Williams GH, Raji A, Jeunemaitre X, Brown NJ, Hopkins PN, Conlin PR. Prevalence of primary hyperaldosteronism in mild to moderate hypertension without hypokalaemia. J Hum Hypertens 2006; 20: 129-136. OS

691 Nishikawa T, Omura M. Clinical characteristics of primary aldosteronism: its prevalence and comparative studies on various causes of primary aldosteronism in Yokohama Rosai Hospital. Biomed Pharmacother 2000; 54 (Suppl 1): 83s-85s. OS

692 Stowasser M, Gordon RD. Primary aldosteronism - careful investigation is essential and rewarding. Mol Cell Endocrinol 2004; 217: 33-39.

693 Nishimura M, Uzu T, Fujii T, Kuroda S, Nakamura S, Inenaga T, Kimura G. Cardiovascular complications in patients with primary aldosteronism. Am J Kidney Dis 1999; 33: 261-266. OS

694 Funder JW, Carey RM, Fardella C, Gomez-Sanchez CE, Mantero F, Stowasser M, Young WF Jr, Montori VM, Endocrine Society. Case detection, diagnosis, and treatment of patients with primary aldosteronism: an Endocrine Society clinical practice guideline. J Clin Endocrinol Metab 2008; 93: 3266-3281.

695 Gordon RD. Primary aldosteronism. J Endocrinol Invest 1995; 18: 495-511. RV

696 Tanabe A, Naruse M, Takagi S, Tsuchiya K, Imaki T, Takano K. Variability in the renin/ aldosterone profile under random and standardized sampling conditions in primary aldosteronism. J Clin Endocrinol Metab 2003; 88: 2489-2494. OS

697 Hiramatsu K, Yamada T, Yukimura Y, Komiya I, Ichikawa K, Ishihara M, Nagata H, Izumiyama T. A screening test to identify aldosterone-producing adenoma by measuring plasma renin activity. Results in hypertensive patients. Arch Intern Med 1981; 141: 1589-1593.

698 Young WF. Primary aldosteronism: renaissance of a syndrome. Clin Endocrinol (Oxford) 2007; 66: 607-618. RV

699 Rossi E, Regolisti G, Negro A, Sani C, Davoli S, Perazzoli F. High prevalence of primary aldosteronism using postcaptopril plasma aldosterone to renin ratio as a screening test among Italian hypertensives. Am J Hypertens 2002; 15: 896-902. OS
700 Schirpenbach C, Seiler L, Maser-Gluth C, Rüdiger F, Nickel C, Beuschlein F, Reincke $M$. Confirmatory testing in normokalaemic primary aldosteronism: the value of the saline infusion test and urinary aldosterone metabolites. Eur J Endocrinol 2006; 154: 865-873. OS

701 Morimoto S, Takeda R, Murakami M. Does prolonged pretreatment with large doses of spironolactone hasten a recovery from juxtaglomerular-adrenal suppression in primary aldosteronism? J Clin Endocrinol Metab 1970; 31: 659-664. CT

702 The Japan Endocrine Society. http://square.umin.ac.jp/endocrine/rinsho_juyo/index.html.

703 Mancini T, Kola B, Mantero F, Boscaro M, Arnaldi G. High cardiovascular risk in patients with Cushing's syndrome according to 1999 WHO/ISH guidelines. Clin Endocrinol (Oxford) 2004; 61: 768-777. OS

704 Neumann HP, Cybulla M, Shibata H, Oya M, Naruse M, Higashihara E, Terachi T, Ling $\mathrm{H}$, Takami $\mathrm{H}$, Shuin T, Murai M. New genetic causes of pheochromocytoma: current concepts and the clinical relevance. Keio J Med 2005; 54: 15-21. RV

705 Gornik HL, Creager MA. Aortitis. Circulation 2008; 117: 3039-3051.

706 Arend WP, Michel BA, Bloch DA, Hunder GG, Calabrese LH, Edworthy SM, Fauci AS, Leavitt RY, Lie JT, Lightfoot RW. The American College of Rheumatology 1990 criteria for the classification of Takayasu arteritis. Arthritis Rheum 1990; 33: 1129-1134.

707 Kobayashi Y, Ishii K, Oda K, Nariai T, Tanaka Y, Ishiwata K, Numano F. Aortic wall inflammation due to Takayasu arteritis imaged with 18F-FDG PET coregistered with enhanced CT. J Nucl Med 2005; 46: 917-922.

708 Miyata T, Sato O, Koyama H, Shigematsu H, Tada Y. Long-term survival after surgical treatment of patients with Takayasu's arteritis. Circulation 2003; 108 : 1474-1480. OS

709 Blaustein DA, Kumbar L, Srivastava M, Avram MM. Polyarteritis nodosa presenting as isolated malignant hypertension. Am J Hypertens 2004; 17: 380-381. OS

710 Toro-Salazar OH, Steinberger J, Thomas W, Rocchini AP, Carpenter B, Moller JH. Long-term follow-up of patients after coarctation of the aorta repair. Am J Cardiol 2002; 89: 541-547. OS

711 Kobayashi S, Yano M, Kohno M, Obayashi M, Hisamatsu Y, Ryoke T, Ohkusa T, Yamakawa $\mathrm{K}$, Matsuzaki M. Influence of aortic impedance on the development of pressure-overload left ventricular hypertrophy in rats. Circulation 1996; 94: 3362-3368.

712 Murakami T, Ueno M, Takeda A, Yakuwa S. Pressure wave reflection after successful balloon dilatation of aortic coarctation. Circ J 2007; 71: 1821-1822. OS

713 Ross RD, Clapp SK, Gunther S, Paridon SM, Humes RA, Farooki ZQ, Pinsky WW. Augmented norepinephrine and renin output in response to maximal exercise in hypertensive coarctectomy patients. Am Heart J 1992; 123: 1293-1299.

714 Jannetta PJ, Segal R, Wolfson SK. Neurogenic hypertension: etiology and surgical treatment. I. Observations in 53 patients. Ann Surg 1985; 201: 391-398.

715 Morimoto S, Sasaki S, Takeda K, Furuya S, Naruse S, Matsumoto K, Higuchi T, Saito M, Nakagawa M. Decreases in blood pressure and sympathetic nerve activity by microvascular decompression of the rostral ventrolateral medulla in essential hypertension. Stroke 1999; 30: 1707-1710. OS

716 Schobel HP, Frank H, Naraghi R, Geiger H, Titz E, Heusser K. Hypertension in patients with neurovascular compression is associated with increased central sympathetic outflow. J Am Soc Nephrol 2002; 13: 35-41.

717 Smith PA, Meaney JF, Graham LN, Stoker JB, Mackintosh AF, Mary DA, Ball SG. Relationship of neurovascular compression to central sympathetic discharge and essential hypertension. J Am Coll Cardiol 2004; 43: 1453-1458.

718 Nicholas JS, D'Agostino SJ, Patel SJ. Arterial compression of the retro-olivary sulcus of the ventrolateral medulla in essential hypertension and diabetes. Hypertension 2005; 46: 982-985.

719 Sendeski MM, Consolim-Colombo FM, Leite CC, Rubira MC, Lessa P, Krieger EM. Increased sympathetic nerve activity correlates with neurovascular compression at the rostral ventrolateral medulla. Hypertension 2006; 47: 988-995.

720 Tan EK, Chan LL. Neurovascular compression syndromes and hypertension: clinical relevance. Nat Clin Pract Neurol 2007; 3: 416-417. RV

721 Brown MJ. The causes of essential hypertension. Br J Clin Pharmacol 1996; 42: 21-27. RT

722 Kato N, Miyata T, Tabara Y, Katsuya T, Yanai K, Hanada H, Kamide K, Nakura J, Kohara K, Takeuchi F, Mano H, Yasunami M, Kimura A, Kita Y, Ueshima H, Nakayama T, Soma M, Hata A, Fujioka A, Kawano Y, Nakao K, Sekine A, Yoshida T, Nakamura Y, Saruta T, Ogihara T, Sugano S, Miki T, Tomoike H. High-density association study and nomination of susceptibility genes for hypertension in the Japanese National Project. Hum Mol Genet 2008; 17: 617-627.

723 Yatsu K, Mizuki N, Hirawa N, Oka A, Itoh N, Yamane T, Ogawa M, Shiwa T, Tabara Y, Ohno S, Soma M, Hata A, Nakao K, Ueshima H, Ogihara T, Tomoike H, Miki T, Kimura A, Mano S, Kulski JK, Umemura S, Inoko H. High-resolution mapping for essential hypertension using microsatellite markers. Hypertension 2007; 49: 446-452.

724 Katsuya T, Ishikawa K, Sugimoto K, Rakugi H, Ogihara T. Salt sensitivity of Japanese from the viewpoint of gene polymorphism. Hypertens Res 2003; 26: 521-525. RV

725 Lifton RP, Gharavi AG, Geller DS. Molecular mechanisms of human hypertension. Cell 2001; 104: 545-556. RV

726 Ministry of Education. Ethics Guidelines for Human Genome/Gene Analysis Research. http://www.mext.go.jp/a menu/shinkou/seimei/genome/04122801.htm.

727 Antman EM, Bennett JS, Daugherty A, Furberg C, Roberts H, Taubert KA, American Heart Association. Use of nonsteroidal antiinflammatory drugs: an update for clinicians: a scientific statement from the American Heart Association. Circulation 2007; 115: 1634-1642. GL

728 Layton D, Souverein PC, Heerdink ER, Shakir SA, Egberts AC. Evaluation of risk profiles for gastrointestinal and cardiovascular adverse effects in nonselective NSAID and COX-2 inhibitor users: a cohort study using pharmacy dispensing data in the Netherlands. Drug Saf 2008; 31: 143-158. OS 
729 Strand V. Are COX-2 inhibitors preferable to non-selective non-steroidal anti-inflammatory drugs in patients with risk of cardiovascular events taking low-dose aspirin? Lancet 2007; 370: 2138-2151. RV

730 Arellano FM, Yood MU, Wentworth CE, Oliveria SA, Rivero E, Verma A, Rothman KJ. Use of cyclo-oxygenase 2 inhibitors (COX-2) and prescription non-steroidal antiinflammatory drugs (NSAIDS) in UK and USA populations. Implications for COX-2 cardiovascular profile. Pharmacoepidemiol Drug Saf 2006; 15: 861-872. OS

731 Cosmetic Ingredient Review Expert Panel. Final report on the safety assessment of glycyrrhetinic acid, potassium glycyrrhetinate, disodium succinoyl glycyrrhetinate, glyceryl glycyrrhetinate, glycyrrhetinyl stearate, stearyl glycyrrhetinate, glycyrrhizic acid, ammonium glycyrrhizate, dipotassium glycyrrhizate, disodium glycyrrhizate, trisodium glycyrrhizate, methyl glycyrrhizate, and potassium glycyrrhizinate. Int J Toxicol 2007; 26 (Suppl 2): 79-112. RV

732 Panoulas VF, Douglas KM, Stavropoulos-Kalinoglou A, Metsios GS, Nightingale P, Kita MD, Elisaf MS, Kitas GD. Long-term exposure to medium-dose glucocorticoid therapy associates with hypertension in patients with rheumatoid arthritis. Rheumatology (Oxford) 2008; 47: 72-75.

733 Sato A, Funder JW, Okubo M, Kubota E, Saruta T. Glucocorticoid-induced hypertension in the elderly. Relation to serum calcium and family history of essential hypertension. Am J Hypertens 1995; 8: 823-828.

734 Iuchi T, Akaike M, Mitsui T, Ohshima Y, Shintani Y, Azuma H, Matsumoto T. Glucocorticoid excess induces superoxide production in vascular endothelial cells and elicits vascular endothelial dysfunction. Circ Res 2003; 92: 81-87. CT

735 Halimi JM, Giraudeau B, Buchler M, Al-Najjar A, Etienne I, Laouad I, Bruyère F, Lebranchu Y. Enalapril/amlodipine combination in cyclosporine-treated renal transplant recipients: a prospective randomized trial. Clin Transplant 2007; 21: 277-284. RT
736 Suzuki S, Aiya T. Research for preparing guidelines for criteria of Epo use. 1993, $165-172$.

737 Miyashita K, Tojo A, Kimura K, Goto A, Omata M, Nishiyama K, Fujita T. Blood pressure response to erythropoietin injection in hemodialysis and predialysis patients. Hypertens Res 2004; 27: 79-84. CT

738 Ohkubo M, Ishimitsu T, Kawaguchi T, Abe M, Yagi S. Efficacy and safety of long-term erythropoietin therapy in chronic hemodialysis patients with renal anemia. Nippon Jinzo Gakkai Shi 1993; 35: 171-177. Japanese.

739 Iseki K, Nakai S, Shinzato T, Morita O, Shinoda T, Kikuchi K, Wada A, Kimata N, Akiba T. Prevalence and determinants of hypertension in chronic hemodialysis patients in Japan. Ther Apher Dial 2007; 11: 183-188. OS

$740 \mathrm{Du}$ Y, Melchert HU, Schäfer-Korting M. Use of oral contraceptives in Germany: prevalence, determinants and use-associated health correlates. Results of National Health Surveys from 1984 to 1999. Eur J Obstet Gynecol Reprod Biol 2007; 134: 57-66. OS

741 Abo-Zena RA, Bobek MB, Dweik RA. Hypertensive urgency induced by an interaction of mirtazapine and clonidine. Pharmacotherapy 2000; 20: 476-478. OS

742 Eisenhofer G, Rivers G, Rosas AL, Quezado Z, Manger WM, Pacak K. Adverse drug reactions in patients with phaeochromocytoma: incidence, prevention and management. Drug Saf 2007; 30: 1031-1062. RV

\section{KEY TO REFERENCES}

$\mathrm{CT}$ : controlled trial; GL: guidelines/experts' opinion; MA: meta-analysis; OS: observational study; RT: randomized trial; RV: review. 